JULIANO RIBEIRO DE LIMA MACHADO

\title{
DIÁRIOS GRATUITOS DESTAK E METRO NO BRASIL: O APROFUNDAMENTO DO DISCURSO PUBLIJORNALÍSTICO
}

Dissertação apresentada ao Programa de PósGraduação em Ciências da Comunicação, Área de Concentração II: Estudo dos Meios e da Produção Mediática, inserido na Linha de

Pesquisa Comunicação Impressa e Audiovisual, da Escola de Comunicações e Artes da Universidade de São Paulo, como exigência parcial para obtenção do Título de Mestre em Ciências da

Comunicação, sob a orientação da Profa. Dra. Nancy Nuyen Ramadan 
Autorizo a divulgação do texto completo em bases de dados especializadas e a reprodução total ou parcial, por processos fotocopiadores, exclusivamente para fins acadêmicos e científicos, desde que citada a fonte.

Assinatura:

Data: 
Autor: MACHADO, Juliano Ribeiro de Lima

Título: Diários gratuitos Destak e Metro no Brasil: o aprofundamento do discurso publijornalístico

Dissertação apresentada à Escola de Comunicações e Artes da Universidade de São

Paulo para obtenção do título de Mestre em Ciências da Comunicação

Banca Examinadora:

Profa. Dra. Nancy Nuyen Ramadan - ECA/USP (orientadora)

Julgamento: Assinatura:

Julgamento: Assinatura:

Julgamento: Assinatura:

Aprovada em: 



\section{Agradecimentos}

Agradeço, primeiramente, à minha orientadora, a Profa. Dra. Nancy Nuyen Ali Ramadan (ECA-USP), pelo apoio sempre que precisei e pela tranquilidade inabalável, mesmo quando a conclusão desta pesquisa me parecia sob risco por conta dos constantes conflitos com o trabalho na redação. Sei dos momentos difíceis pelos quais ela passou ao longo do período de orientação e reconheço todo o esforço que fez para me auxiliar.

Sou grato a meus pais, pelo eterno afeto e pelo incentivo em todas as atividades que me disponho a fazer.

A ideia que fez nascer esta pesquisa não teria sido desenvolvida se não fossem os relatos quase diários que ouvia de Liuca Yonaha a respeito do funcionamento de um jornal gratuito, tanto do Destak quanto do Metro, para os quais ela trabalhou. Liuca foi a fonte primordial de conhecimento prático sobre o fazer jornalístico desses veículos. A partir das nossas conversas, percebi que valia a pena me aprofundar no tema.

Outro incentivador fundamental nestes dois anos e meio, e mesmo antes de eu me candidatar a uma vaga de mestrado, foi Ivan Paganotti. Colega de classe no Jornalismo na ECA, amigo e pesquisador extremamente capaz, Ivan sempre foi a pessoa a quem recorria quando tinha dúvidas sobre o que fazer em determinado momento da vida de mestrando. Não por acaso, eu o apelidei carinhosamente de "assessor para assuntos acadêmicos”. Foi Ivan, com seus conselhos inestimáveis, quem me sugeriu cursar a disciplina "Propaganda, Identidade e Discurso", ministrada pelo Prof. Dr. Eneus Trindade Barreto Filho. Com sua didática clara e estímulo constante à leitura, o Prof. Eneus me fez enxergar uma possível nova abordagem para minha pesquisa. E foi exatamente por causa de suas aulas que eu a conduzi para um outro rumo: entender como os jornais gratuitos se aproximaram da linguagem publicitária. Como examinador de minha qualificação, o Prof. Eneus fez reparos importantes e me deu sugestões de leitura que, mais tarde, se comprovariam indispensáveis.

Estendo meus agradecimentos ao Prof. Dr. Cláudio Novaes Pinto Coelho, da Cásper Líbero. Ao lado do Prof. Eneus, deu-me orientações bastante práticas sobre como deveria guiar a pesquisa na hora de escrevê-la.

Não poderia esquecer-me de outros valiosos amigos da minha turma de Jornalismo, que sempre estão próximos de mim nos bons momentos. Faço uma menção especial a Luciana Hiromi Yamada da Silveira, por também ter vivido as angústias do mestrado e por ter sido uma conselheira muito útil.

Seria injusto de minha parte não reconhecer o apoio que meus colegas de redação na revista Época me ofereceram durante todo o processo. Quando me mudei do jornal O Estado de S. 
Paulo para lá, no início de 2008, já lhes dissera que gostaria de me inscrever no exame da pósgraduação da ECA-USP e que precisaria de algum tempo livre para me dedicar à pesquisa caso conseguisse a vaga. Pois foi o que aconteceu. Em nenhum momento me foi negada a possibilidade de tirar um dia de folga por causa do mestrado, mesmo que isso implicasse algum prejuízo para o fechamento da revista. Agradeço especialmente a meus chefes nesses anos, pois sem o aval deles certamente não teria chegado até aqui. Minhas saudações a André Fontenelle, David Cohen, Helio Gurovitz e Rogério Simões.

A pesquisa só ganhou concretude porque tive acesso facilitado a arquivos e dados dos gratuitos Destak e Metro. Meus agradecimentos vão para toda a equipe dos dois jornais, em especial para Noelly Russo (que não está mais no Metro, mas foi muito atenciosa em sua entrevista para este trabalho) e para Fábio Santos, o multitarefas diretor editorial do Destak.

Por fim, na parte derradeira desta pesquisa, minhas lembranças a João Faria, assessor da agência de publicidade DPZ, por tão gentilmente ter cedido a mim cópias digitais de dois anúncios que compõem o corpus desta pesquisa. Por igual razão, agradeço também a Renata Martins, da agência Full Jazz. 


\section{Resumo}

Objetivo: Os anúncios veiculados nas capas dos jornais gratuitos Metro e Destak, de São Paulo, apresentam um nível de diálogo entre linguagem publicitária e jornalística pouco comum ao que se observa nos periódicos tradicionais. A aproximação entre esses dois campos também é sentida em algumas chamadas de capa - gênero marcadamente jornalístico - que recorrem a vários elementos do discurso publicitário. Esta pesquisa busca identificar os mecanismos utilizados pelos anunciantes de jornais gratuitos e pelo veículo em si para obter tal efeito nos dois casos analisados. Métodos: Os conceitos de dialogia de Mikhail Bakhtin e da Análise de Discurso francesa são a principal fundamentação teórica a ser aplicada em uma seleção de anúncios e chamadas nas capas de Metro e Destak. Resultados: embora o mercado jornalístico cultive uma imagem dos gratuitos como concorrentes dos jornais pagos populares, as conclusões da análise do corpus reforçam uma estratégia definida pelos gratuitos de se associar a um público jovem, urbano e de bom poder aquisitivo.

Palavras-chave: jornais gratuitos; discurso publicitário; discurso jornalístico; dialogia; análise de discurso

\section{Abstract}

Objective: The advertisements published on the front page of the free dailies Metro and Destak, from São Paulo, show a level of dialogue between advertising and journalistic language that is not commonly seen in traditional newspapers. These two discourses get also closer in some top headlines - a traditional room for journalistic content - that incorporate many elements of the advertising discourse. This study is aimed at identifying the strategies used by both advertisers and the media outlet itself to prompt this effect. Methods: The concepts of dialogism by Mikhail Bakhtin and the French Discourse Analysis are the theoretical basis to be applied to a selection of advertisements and top headlines of Metro and Destak. Results: although the journalistic market regards the free dailies as competitors to popular newspapers, the conclusions drawn from our analysis emphasize a strategy adopted by the free dailies of associating their brand with a young, urban, wealthy audience.

Keywords: free dailies; advertising discourse; journalistic discourse; dialogism; Discourse Analysis 


\section{Lista de gráficos}

Gráfico 3.2.1 - Divisão de leitores do Metro por faixa etária......................................... p. 050

Gráfico 3.2.2 - Divisão de leitores do Metro por classificação sócio-econômica............. p. 051

Gráfico 3.2.3 - Divisão de leitores do Metro por sexo.................................................... p.051

Gráfico 3.2.4 - Divisão de leitores do Destak por faixa etária ...................................... p. 052

Gráfico 3.2.5 - Divisão de leitores do Destak por classificação sócio-econômica .......... p. 052

Gráfico 3.2.6 - Divisão de leitores do Destak por sexo............................................... p.053

Gráfico 3.3.1 - Circulação média diária dos jornais pagos........................................... p. 068

Gráfico 3.3.2 - Volume de páginas comercializadas para publicidade em jornais pagos. p 068

\section{Lista de tabelas}

Tabela 1.1 - Circulação dos principais jornais brasileiros em 2010 ............................... p. 014

Tabela 2.2.1 - Gêneros de discurso instituídos, de Dominique Maingueneau................. p. 025

Tabela 3.1.1 - Os três lugares da máquina midiática, de Patrick Charaudeau................. p. 040

Tabela 3.1.2 - Discurso publicitário versus discurso jornalístico................................... p. 042

Tabela 3.3.1 - Modelos de ingresso de mercado dos jornais gratuitos modernos............ p. 064

Tabela 3.3.2 - Modelos de reação da imprensa tradicional............................................ p. 066

\section{Lista de figuras}

Figura 1.1 - Reprodução do primeiro número do diário Metro, de Estocolmo................. p.008

Figura 3.2.1 - Reprodução do site brasileiro do diário Metro........................................... p.046

Figura 3.2.2 - Modelos em campanha do Metro de divulgação do NudeDay.................. p.048

Figura 3.2.3 - Mapa dos pontos de distribuição do Metro em São Paulo..........................p. 054

Figura 3.2.4 - Capas do Metro com Lady Gaga................................................................p.061

Figura 5.1 - Reprodução da capa do Destak de 15/06/2007 …...................................... p. 073

Figura 5.2 - Reprodução da sobrecapa do Metro de 19/10/2007..................................... p.076

Figura 5.3 - Reprodução da sobrecapa do Destak de 06/12/2007.....................................p.077

Figura 5.4 - Reprodução da sobrecapa do Destak de 16/05/2008.....................................p.080

Figura 5.5 - Reprodução da página 2 do anúncio no Destak de 16/05/2008......................p.081

Figura 5.6 - Reprodução da página 3 do anúncio no Destak de 16/05/2008......................p.082

Figura 5.7 - Reprodução da página 4 do anúncio no Destak de 16/05/2008......................p.083

Figura 5.8 - Reprodução da sobrecapa do Destak de 27/03/2009.....................................p.086

Figura 5.9 - Reprodução da contracapa do Destak de 27/03/2009....................................p. 087

Figura 5.10 - Reprodução da sobrecapa do Metro de 07/02/2011 ….............................. p. 090 
Figura 5.11 - Reprodução da capa do Metro de 07/02/2011 ..............................................p.091

Figura 5.12 - Reprodução da sobrecapa da Folha de S. Paulo de 20/06/2011...................p.097

Figura 5.13 - Reprodução da capa da Folha de S. Paulo de 20/06/2011...........................p.098

Figura 5.14 - Reprodução da capa do Destak de 09/02/2011............................................p.101

Figura 5.15 - Reprodução da capa do Metro de 09/02/2011 ..............................................p.102

Figura 5.16 - Reprodução da capa do Metro de 10/03/2011 ..............................................p.104

Figura 5.17 - Reprodução do cartaz de divulgação da animação Rio.............................. p.107

Figura 5.18 - Reprodução da capa da Folha de S. Paulo de 23/03/2011.......................... p.108

Figura 5.19 - Reprodução da capa do Destak de 22/03/2011 ............................................p.109

Figura 5.20 - Reprodução da capa do Metro de 22/03/2011 .............................................p.110 


\section{Sumário}

1. Introdução: Um “diferente tipo de animal” chamado jornal gratuito moderno p.007

\section{Parte I - Aspectos formais}

2. Metodologia. p.019

2.1. Objeto da pesquisa: $O$ discurso publijornalístico p.020

2.2. Teoria metodológica: gêneros de discurso e interdiscurso p.021

2.2.1. O ethos - De Aristóteles à análise de discurso p.028

2.3. Prática metodológica p. 031

2.4. Procedimentos metodológicos p.033

3. Referencial teórico, conceitual e contextual p. 036

3.1. Aproximação dos discursos publicitário e jornalístico. p. 037

3.2. O ethos dos gratuitos modernos na sociedade de consumo p. 046

3.3 Reação da mídia tradicional à chegada dos gratuitos p. 064

\section{Parte II - Análise do Discurso sobre os jornais gratuitos}

4. Anúncios publicitários e chamadas de capa de Metro e Destak p. 070

\section{Parte III - Considerações finais}

5. Considerações finais: No meio do caminho entre jornalismo e publicidade. p. 111

Referências Bibliográficas p. 117 


\section{INTRODUÇÃO: UM “DIFERENTE TIPO DE ANIMAL” CHAMADO JORNAL GRATUITO MODERNO}

“- Isso já foi feito antes alguma vez?

- Não.

- Ótimo. Então vamos fazer.”1

Antes de ouvir o "sim” do empresário Jan Stenbeck, em 1995, o trio de amigos e jornalistas suecos Pers Anderson, Robert Braunerhielm e Monica Anderson já havia batido em muitas portas. Eles buscavam alguém disposto a bancar o lançamento de um jornal diário gratuito em Estocolmo, capital da Suécia, que seria distribuído preferencialmente em estações do metrô durante os dias de semana. A ideia fora concebida por eles ainda no início da década de 90, mas ninguém queria assumir o risco de financiar a empreitada - na lista dos descrentes havia de banqueiros a diretores de empresas midiáticas. Até que a proposta dos três chamou a atenção de Pelle Tornberg, então responsável pelas operações de telecomunicação da AB Kinnevik, um grande conglomerado sueco que nasceu como companhia de investimentos e se expandiu para vários setores, entre eles o de mídia.

Tornberg queria diversificar as atividades do Kinnevik, e entrar no mercado de jornais impressos era uma possibilidade interessante para o grupo. Mas o executivo se sentia desestimulado pelo cenário pouco atraente naquela época para a mídia sueca. “A leitura de impressos vinha em declínio há muitos anos, e o leitor médio tinha mais de 50 anos. Os indicadores para a publicidade eram terríveis”, afirmou Tornberg em uma entrevista à revista Business Week. ${ }^{2}$

Diante da ideia ousada de uma publicação gratuita voltada a usuários de transporte público, ele vislumbrou um modo de atrair um público leitor mais jovem e ativo - era uma maneira, na sua concepção, de apostar em um filão do mercado ainda pouco explorado e que talvez pudesse ser promissor. Tornberg, então, convenceu seu chefe, Jan Stenbeck, a receber aqueles três jornalistas. O Kinnevik acabara de criar uma divisão voltada apenas para a mídia, chamada Modern Times Group (MTG). E foi a MTG, após a reunião em que Stenbeck bateu o martelo sobre o investimento, que viabilizou o surgimento do diário Metro (o nome veio como uma associação natural ao meio de transporte em que a distribuição ocorreria). A primeira edição saiu em 13 de fevereiro de 1995, com a seguinte capa:

\footnotetext{
${ }^{1}$ Diálogo extraído do site oficial do Metro International (http://www.metro.lu/about/metro_history)

2 Edição de 07/06/2004. Disponível em http://www.businessweek.com/magazine/content/04_23/b3886206.htm
} 
Diários gratuitos Destak e Metro no Brasil - Juliano Machado

1. Introdução

Figura 1.1 - Reprodução do primeiro número do diário Metro, de Estocolmo
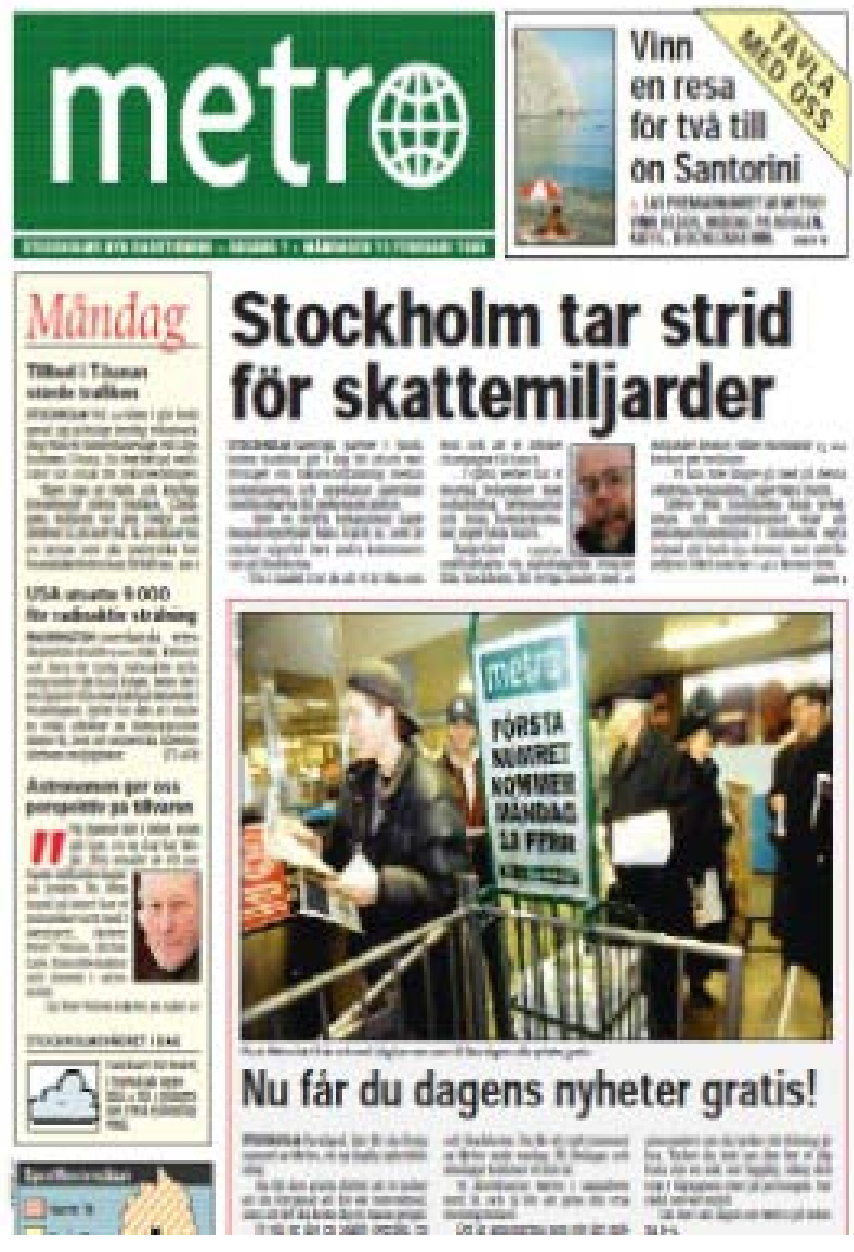

A foto principal trazia usuários do metrô lendo os primeiros exemplares, e a submanchete dizia: “Agora você tem as notícias do dia de graça!” Era uma mensagem destinada, evidentemente, aos moradores de Estocolmo, mais especificamente aos que habitualmente utilizavam o metrô para seus deslocamentos diários. Esse público não tinha acesso, até então, a nenhum veículo impresso que oferecesse informação sem que tivesse de dar algum tipo de contrapartida. Ou, na definição de Nieto, a imprensa gratuita é

(...)el producto de la actividad editorial de una empresa, periodística o no, que lo entrega sin la adecuada contraprestación económica por parte de los receptores, y cuyo único o primordial ingreso procede de los anúncios que publica, difundiendo exclusivamente mensajes publicitários o también informaciones de carácter general o especializado (NIETO apud CASTAÑO, 2002, p. 267) ${ }^{3}$

\footnotetext{
${ }^{3}$ Tradução do autor: “(...)o produto da atividade editorial de uma empresa, jornalística ou não, que o entrega sem a adequada contraprestação econômica por parte dos receptores, e cuja única ou primordial renda vem dos anúncios que publica, difundindo exclusivamente mensagens publicitárias ou também informações de caráter geral ou especializado.”
} 
Neste conceito mais amplo, o que o Metro trazia não era propriamente uma inovação. Os precedentes da imprensa gratuita, diz Nieto (2002), remontam aos séculos XVIII e XIX e sempre estiveram intimamente vinculados à publicidade. Exemplo disso eram os negócios do jornalista francês Charles Louis-Havas (1785-1858), que viria a fundar o embrião do que hoje é a prestigiada agência de notícias France Presse. Havas oferecia notícias gratuitas a periódicos clientes de sua agência desde que, em troca, estes inserissem anúncios do interesse dele em suas páginas. No fim do século XIX, consolidaram-se as chamadas publicações publicitárias, que nada mais eram do que encartes exclusivamente preenchidos com anúncios e distribuídos gratuitamente. Assim era o General-Anzeiger für Lübeck und Umgebung (algo como “Diário Geral para Lübeck e Arredores”, em alemão), lançado na cidade alemã de mesmo nome em 1882 e cuja circulação se tornou diária três anos depois.

Apesar de alguns outros casos isolados na Alemanha e também na Austrália, os primeiros periódicos gratuitos com orientação maior ao conteúdo noticioso - sem se afastar da publicidade, diga-se - popularizaram-se nos Estados Unidos dos anos 1940. Tratava-se de veículos que refletiam uma imprensa fragmentada, mais voltada para as demandas de uma comunidade específica e editada por alguns segmentos da sociedade civil que não os representantes de grupos midiáticos já consolidados (NIETO apud EDO, 2005). Nesse perfil se encaixava, por exemplo, o Colorado Daily, surgido em 1953 por iniciativa de estudantes da Universidade do Colorado - na verdade, a publicação existia desde 1892 com outro nome, Silver \& Gold, mas apenas como um folheto estudantil. O jornal atendia basicamente à demanda de informação da população acadêmica e de parte da população da cidade de Boulder, onde fica a universidade. O Colorado Daily ganhou notoriedade nos Estados Unidos em 1970, quando foi banido do campus por causa de editoriais criticando a participação americana na Guerra do Vietnã. No ano seguinte, diante da proibição, o jornal passou da mão dos estudantes para um grupo de mídia local. Existe até hoje como jornal gratuito. Em seu site, o Colorado Daily se define como "a pioneer in the advertising supported free daily paper movement that today is seen all over the nation"4.

Tal definição é interessante para o escopo deste trabalho por duas razões. A primeira é por identificar um "movimento de diários gratuitos” com ampla difusão na atualidade, algo que comprovaremos com dados globais mais adiante, nas justificativas sobre a relevância desta pesquisa. A segunda razão é pelo fato de o Colorado Daily se considerar o veículo desencadeador desse fenômeno midiático. É necessário reconhecer que esse periódico se

\footnotetext{
${ }^{4}$ Disponível em http://www.coloradodaily.com/about-us\#axzz1VA0wYet4. Tradução do autor: "pioneiro no movimento de diários gratuitos sustentados por anúncios que hoje está difundido por toda a nação"
} 
mantém rentável desde o início dos anos 1970 sob o modelo da gratuidade financiada por anúncios. No entanto, seu eixo de atuação sempre foi municipal; a maioria das pautas é focada em assuntos da cidade. Sua tiragem diária não passa de 15 mil exemplares. O Colorado Daily nunca incomodou nenhum dos grandes veículos americanos. Um dos pontos que este trabalho visa a provar é que a mídia gratuita permaneceu sob uma ótica empresarial pouco ambiciosa até o surgimento do Metro, em 1995. Desde então, o modo de o mercado midiático encarar os jornais gratuitos sofreu uma mudança significativa, mesmo nos locais em que já havia periódicos distribuídos sem custo ao público. É o caso de São Paulo, que desde 1974 contava com o gratuito Metrô News e só veio a conhecer o Metro em 2007, numa associação da Metro International com o Grupo Bandeirantes de comunicação que levou ao lançamento do diário PubliMetro (mais conhecido e doravante aqui chamado apenas de Metro). Um ano antes, era lançado na capital paulista o português Destak, que segue o mesmo formato do jornal sueco.

Pelo fato de ainda ser um fenômeno relativamente recente na mídia mundial, o aparecimento do Metro e de seus congêneres ao redor do mundo recebeu a atenção de alguns poucos estudiosos. Um dos pesquisadores que mais avançaram nesse campo é Piet Bakker, professor do Departamento de Comunicação da Universidade de Amsterdã, na Holanda, e responsável pelo blog Newspaper Innovation (http://www.newspaperinnovation.com), totalmente voltado a novidades no mercado de jornais gratuitos. É dele o termo “jornal gratuito moderno” para definir Metro, Destak e outros títulos assemelhados, conceito que será adotado daqui para frente. Eis sua definição:

The new free newspaper is a different kind of animal. It is aimed at the general public in metropolitan areas (..) and they have a comparatively cheap distribution system, mostly through the public transport system (BAKKER, 2002, p. 02) ${ }^{5}$

Em entrevista a este autor, concedida por e-mail em maio de 2010, Piet Bakker detalhou os aspectos que levaram o Metro a ter criado um novo formato.

\footnotetext{
The free sheets have been published since the industrial revolution. Even so, the modern free daily is a new product due to its great difference from the original free papers. Modern free papers are often times dailies; their target is often young urban people. And we can see them as the first true competitors to the traditional newspapers. ${ }^{6}$
}

\footnotetext{
${ }^{5}$ Tradução do autor: “O novo jornal gratuito é um diferente tipo de animal. Está direcionado ao público geral das áreas metropolitanas. Eles possuem um sistema de distribuição comparativamente barato (na comparação com os jornais pagos tradicionais), majoritariamente por meio do transporte público.”

${ }^{6}$ Folhetos gratuitos têm sido publicados desde a Revolução Industrial. Mesmo assim, o diário gratuito moderno é um novo produto devido à grande diferença em relação aos periódicos gratuitos anteriores. Os periódicos
} 
A chegada de um "diferente tipo de animal” no mercado da mídia tem de ser considerada sob a ótica da tríade de atores básicos presentes nessa área: as empresas e funcionários responsáveis pelas publicações; o público-alvo e, por fim, os anunciantes que vão se interessar em divulgar seu produto naquele determinado veículo. O equilíbrio entre essas três peças é fundamental para o sucesso de qualquer publicação jornalística. Num nível mais superficial, existe uma concepção de que o trabalho jornalístico se afasta do publicitário por ter um compromisso com a verdade e a objetividade. Uma análise mais detida sobre a forma como essas duas linguagens operam, porém, desfaz com rapidez essa ideia e nos leva a encontrar similitudes entre elas. Ambas visam, em última instância, à busca do lucro para suas instituições. E, acima de tudo, direcionam-se a determinados segmentos sociais (o públicoalvo da tríade), que tendem a ser coincidentes para que haja o interesse mútuo. Tanto jornalismo como publicidade agregam seres humanos em busca de uma identidade, de uma personalidade que os vinculem à sociedade de alguma maneira (CASAQUI, 2000, p. 174). O estabelecimento de um novo formato de publicação noticiosa advindo do Metro traz uma consequente reação dos veículos convencionais, do público-leitor de jornais e também do mercado publicitário. Os dois primeiros fenômenos, evidentemente relevantes, serão mencionados neste trabalho, mas o foco estará no terceiro desdobramento. Os gratuitos encabeçados pelo Metro passam a aprofundar a relação entre conteúdo noticioso e publicitário nas páginas de um jornal de uma maneira que o segmento de mídia no Brasil ainda não conhecera anteriormente. É esta ideia que se pretende desenvolver adiante.

\section{Objetivos}

Esta dissertação foi desenvolvida para o Mestrado do Programa de Pós-Graduação em Ciências de Comunicação da Escola de Comunicações e Artes da Universidade de São Paulo. Busca identificar os pontos de contato entre a linguagem jornalística e a publicitária nos dois jornais gratuitos modernos que circulam na cidade de São Paulo: Metro e Destak. Para tanto, o trabalho vai se valer dos anúncios publicados nas capas desses dois jornais entre $1^{0}$ de janeiro e 31 de março de 2011; de outros anúncios publicados fora desse recorte temporal, mas compreendidos por este autor como relevantes para a pesquisa; e de determinadas chamadas de capa dos gratuitos em que há uma confluência de sentidos entre jornalismo/entretenimento/publicidade. Também serão utilizados para o estudo os anúncios de 
capa do jornal Folha de S. Paulo publicados dentro do recorte sugerido e exemplos representativos fora desse período. A partir do emprego dos conceitos de dialogia de Bakhtin (2003) e das classificações de gênero de discurso propostas pelo linguista russo e principalmente por Maingueneau (2003; 2008), serão avaliados os mecanismos pelos quais ocorre o imbricamento entre as duas linguagens em anúncios de capa dos gratuitos. $\mathrm{O}$ uso das capas da Folha de S. Paulo servirá como comparação entre o que se vê em um jornal gratuito e em um chamado quality paper convencional, caso da Folha. Por meio dessa análise conjunta, pretende-se mostrar formatos da mensagem publicitária, detectáveis nas páginas de Metro e Destak, que não encontram paralelo nas capas da Folha, ao menos no recorte de tempo proposto pela pesquisa. Em entrevista concedida a este autor no ano passado, o pesquisador Piet Bakker afirma que o Metro e seus congêneres reformularam o perfil da publicidade em jornais.

\begin{abstract}
Metro uses wraps, fake covers, special issues, cut-out ads, gifts etc. They are more innovative than paid papers, most of those would never sell their front page. This and the fact they have a different audience could indeed impact the ad revenues of paid papers, however, it is hard to come up with numbers in this respect. The first question would be: where did these companies advertise before? $^{7}$
\end{abstract}

Não faz parte dos objetivos desta pesquisa encontrar elementos para responder à pergunta da última frase de Bakker, mas sim identificar exemplos desse fenômeno e demonstrar como operam os mecanismos pelos quais os limites entre o que é publicidade e o que é jornalismo praticamente se esvanecem em um diário gratuito moderno.

\title{
Justificativa sobre a relevância da pesquisa
}

Os jornais gratuitos modernos existem há 16 anos - como já dito anteriormente, a primeira edição do Metro saiu às ruas de Estocolmo, na Suécia, no dia 13 de fevereiro de 1995. Embora seja um tipo de veículo de comunicação bastante novo ante os tradicionais jornais pagos e outros meios, o mercado dos gratuitos modernos ostenta números que não podem ser desprezados. De acordo com estimativas feitas no ano passado pelo blog especializado Newspaper Innovation, aproximadamente 35 milhões de exemplares de jornais gratuitos são distribuídos todos os dias em 53 países ao redor do mundo, alcançando um

\footnotetext{
${ }^{7}$ Tradução do autor: “O Metro usa anúncios envelopados, capas falsas, edições especiais, anúncios destacáveis, brindes etc. Eles são mais inovadores que os jornais pagos, muitos dos quais nunca venderiam sua capa. Isso e o fato de eles (gratuitos) terem um diferente público poderia, de fato, trazer impacto às receitas publicitárias de jornais pagos, mas é difícil chegar a números a esse respeito. A primeira questão seria: onde essas companhias anunciavam antes (da existência dos gratuitos)?”
} 
público-leitor de 70 milhões a 100 milhões de pessoas. Em quatro países da Europa (Dinamarca, Espanha, Islândia e Portugal), eles já superam os veículos impressos pagos em número de exemplares distribuídos entre segunda-feira e sexta-feira. No continente europeu, um em cada cinco exemplares de jornais diários é gratuito. Nos últimos cinco anos até 2010, a circulação desses jornais aumentou 58\%, segundo um levantamento da Associação Mundial de Jornais (WAN, na sigla em inglês).

O Metro é o veículo dominante do setor. Está presente em 23 países, onde possui 84 edições diárias. Somados todos os Metros do mundo, a circulação diária é de cerca de 8 milhões de exemplares. Isso o coloca, dependendo de variações como o fechamento ou a criação de uma nova edição, em segundo ou terceiro maior jornal do mundo em termos de tiragem diária, contando também os jornais pagos. O maior de todos é o Yomiuri Shimbun, sediado em Tóquio, com uma tiragem de aproximadamente 10 milhões de exemplares diários. Em segundo lugar está o também japonês Asahi Shimbun, que distribui os mesmos 8 milhões de cópias que o Metro.

No Brasil, os gratuitos modernos estão presentes há apenas cinco anos - é importante lembrar que não estamos levando em conta o diário paulistano Metrô News, de 1974, por não se encaixar nos critérios de classificação a serem mais detalhados adiante, no capítulo 3.2 (O ethos dos gratuitos modernos na sociedade de consumo). Mesmo com tão pouco tempo de Brasil, não se pode dizer que se trate de um segmento marginalizado do mercado jornalístico. Se forem somadas todas as suas edições (São Paulo, ABC, Campinas, Santos, Rio de Janeiro e Curitiba), o Metro alcança uma tiragem diária de 360 mil exemplares. O Destak, por sua vez, chega a 290 mil cópias por dia com suas edições em São Paulo, Rio de Janeiro e Brasília. Ambos não são filiados ao Instituto Verificador de Circulação (IVC), empresa que audita os principais jornais brasileiros - a auditoria dos dois gratuitos é feita pela DBO. Se estivessem na lista do IVC, ocupariam, respectivamente, o primeiro e quarto lugares. Segundo os números do IVC relativos ao ano passado, o jornal pago com maior tiragem foi o popular Super Notícia, de Minas Gerais, com 295 mil cópias diárias. O quality paper Folha de S. Paulo vem logo atrás, com 294 mil exemplares, como se pode ver na Tabela 1.1 a seguir: 
Diários gratuitos Destak e Metro no Brasil - Juliano Machado

1. Introdução

Tabela 1.1 - Circulação dos principais jornais brasileiros em 2010

\begin{tabular}{|c|c|c|c|}
\hline Posição & Jornal & Várias & 360.000 \\
\hline $1^{*}$ & Metro & Belo Horizonte & 295.701 \\
\hline 2 & Super Notícia & São Paulo & 294.498 \\
\hline 3 & Folha de S. Paulo & Várias & 290.000 \\
\hline $4^{*}$ & Destak & Rio de Janeiro & 262.435 \\
\hline 5 & O Globo & Rio de Janeiro & 238.236 \\
\hline 6 & Extra & São Paulo & 236.369 \\
\hline 7 & O Estado de S. Paulo & Porto Alegre & 184.663 \\
\hline 8 & Zero Hora & Rio de Janeiro & 157.654 \\
\hline 9 & Meia Hora & Porto Alegre & 157.409 \\
\hline 10 & Correio do Povo & Porto Alegre & 150.744 \\
\hline 11 & Diário Gaúcho & São Paulo e Rio & 94.683 \\
\hline 12 & Lance & & \\
\hline
\end{tabular}

Fontes: Instituto Verificador de Circulação e *auditoria BDO

É necessário atentar para o fato de que os números referentes aos jornais pagos se referem à distribuição em todo o Brasil, ao passo que os exemplares dos gratuitos estão divididos apenas entre as cidades onde há edições. Por esse ângulo já é possível ter uma ideia da presença dos gratuitos nos locais onde atuam e a dimensão desse novo negócio no país. Depois de passarem por um período de adaptação, esses veículos parecem estar consolidados no mercado brasileiro.

\section{Justificativa sobre a originalidade da pesquisa}

A razão mais evidente para a proposição desta pesquisa é a quase ausência de estudos sobre jornais gratuitos modernos nas faculdades de comunicação. Pude comprovar esse cenário ao pesquisar o acervo de bibliotecas de três prestigiadas instituições: a Escola de Comunicações e Artes da Universidade de São Paulo (ECA-USP), a Universidade Metodista e a Pontifícia Universidade Católica de São Paulo (PUC-SP). Em nenhuma delas há ao menos uma dissertação de mestrado ou tese de doutorado que trate do fenômeno dos jornais gratuitos modernos pelo mundo, tampouco no Brasil. Apenas na ECA-USP há um Trabalho de Conclusão de Curso, de autoria de Letícia Nigro Mazon e datado de 2009, cujo tema é o jornal Metro, intitulado “O Modelo Econômico do Jornal Diário Gratuito: Metro International e Publimetro, um estudo de caso”. Não se trata, porém, de um estudo voltado para o modus operandi dos gratuitos modernos na relação entre discurso jornalístico e suas conexões com o discurso publicitário. Em suma, ainda são muito raras as reflexões de pesquisadores 
brasileiros da área de comunicação sobre esse segmento. Diante dessa escassez de análise sobre o setor, o projeto se mostra útil para tornar mais rico o debate em torno do processo de acomodação dos gratuitos no mercado de mídia impressa.

\section{Justificativa sobre a motivação do pesquisador}

Uma pesquisa acadêmica não pode ser justificada totalmente se não houver uma apresentação de motivos pelos quais o próprio autor do estudo se interessou sobre o objeto em questão. Minha curiosidade sobre os gratuitos modernos começou a se formar ainda em abril de 2002, portanto, quatro anos antes da pioneira chegada do Destak ao Brasil. Estava no segundo ano da graduação de jornalismo na ECA-USP e li um artigo de Alcino Leite Neto publicado na então Folha Online (hoje Folha.com) sobre sua experiência com os gratuitos em Paris. Neto fazia um prognóstico do alcance desse tipo de jornal por aqui.

Na padaria da esquina em Paris você encontra o jornal Metro, os exemplares encaixados num suporte de plástico. Pode pegar, é de graça. O jornal, em formato tabloide, circula na cidade desde fevereiro e está deixando de cabelos em pé os seus concorrentes pagos, sobretudo os que editam jornais populares. No interior da França, é um produto em expansão.

No Metro, comparecem todas as notícias importantes do dia no mundo, no país e na cidade. São textos curtos, escritos de maneira simples, com várias explicações. Lê-se tudo em 15 minutos. Praticamente não há análises nem grandes reportagens investigativas. O jornal vive da publicidade e dos classificados, de onde vem aliás o grosso da renda dos próprios jornais pagos. Por que o Metro pôde circular agora em Paris, onde corre a fama de que há gente de leitura sofisticada e exigente?

É que a massa de leitores fica cada vez mais inculta, sem falar que existe um novo público potencial, formado de imigrantes de poucas letras, seja em francês ou na sua língua pátria, para quem os jornais de primeiro time, como o Libération ou Le Monde, parecem difíceis e inacessíveis, além de caros (o preço de um jornal dá para comprar duas baguettes).

No Brasil, jornais como o Metro também aparecerão em breve. Serão distribuídos nos pontos de ônibus, no centro das cidades, nas padarias. A informação impressa será de graça, como na TV.

O sucesso desses jornais depende do universo cultural em que eles surgem. Na França, sua presença tem crescido, mas não é dominante. Os jornais franceses de prestígio vão buscando, com alguma eficácia, alternativas para tornarem a sua linguagem mais clara e ao mesmo tempo mais próxima dos jovens leitores e daqueles cuja formação não é nenhuma maravilha, o consumidor futuro, de um mundo pós-letrado.

No Brasil, a expansão de jornais como o Metro poderá ser dominante, dada a má formação educacional e a baixa renda da população. Seu sucesso não afetará comercialmente os jornais de qualidade, mas sim as publicações populares que ainda restam. É um problema para os empresários de mídia: diz respeito à sobrevivência de seus produtos populares pagos. Os mais espertos tratarão de planejar desde já os seus "gratuitos”.

É bom que existam jornais gratuitos, sobretudo para uma população que não tem o hábito de lê-los, nem dinheiro para comprá-los. A curto prazo, significa que os jornais entrarão em casas onde jamais comparecem. A longo prazo, que um costume de leitura poderá ser criado. O otimismo também assegura que transformações culturais podem ser promovidas por esses jornais, se eles 
não forem manipulados politicamente, se forem realizados com responsabilidade social.

Os jornais gratuitos são a melhor notícia para a sobrevivência da imprensa escrita nos últimos anos, depois da internet - e mais democrática do que essa, sobretudo num país como o Brasil, onde menos de $5 \%$ possuem computadores.

Os "gratuitos” não deveriam ser vistos pelos leitores “de elite” nem pela classe jornalística com preconceito, mas com esperança. Compete a essa classe tomar para si desde já, como causa, a sua defesa, a fim de não deixálos largados à mera empreitada comercial e, com o trabalho jornalístico, assegurar a qualidade democrática da informação e o potencial transformador das publicações que a gente apanha de graça na padaria. ${ }^{8}$

Até ler esse artigo, não tinha nenhum conhecimento sobre esse modelo de jornal gratuito. Ao longo de toda a faculdade, nenhum docente apresentou algum material sobre esse fenômeno midiático que já estava se espalhando intensamente pela Europa. O tempo passou, comecei a trabalhar em redações de jornais convencionais, e acabei me esquecendo do assunto.

Só voltei a ouvir sobre gratuitos no início de 2006, quando começaram rumores nos círculos de jornalistas de que seria lançada em São Paulo uma versão do Destak português, o que viria realmente a ocorrer meses depois. Foi aí que me veio à mente o artigo de quatro anos antes. Fiz questão de relê-lo e me detive justamente no parágrafo acima citado. Leite Neto fazia uma espécie de aposta dos gratuitos no Brasil. Pensei se tudo o que ele previa ali poderia se concretizar. As hipóteses lançadas por Leite Neto no restante do artigo eram as seguintes:

1) os gratuitos poderão ser dominantes no Brasil

2) os gratuitos ganharão espaço em razão do baixo nível de escolaridade e da baixa renda da população

3) os gratuitos não vão competir com os quality papers

4) os gratuitos vão ocupar o espaço de títulos populares das empresas jornalísticas

5) as empresas jornalísticas tradicionais do Brasil vão se antecipar ao fenômeno e lançar seus próprios títulos gratuitos

Essas questões ficaram em suspenso para mim durante o período em que saí da universidade para o mercado de trabalho e deixei de manter uma vida acadêmica. Não tenho acesso diário aos exemplares do Metro ou do Destak porque não transito muito nas regiões em que eles são distribuídos, mas sempre acompanhei a trajetória desses veículos por meio de colegas que neles trabalham. Quando tive a oportunidade de me candidatar para um mestrado

\footnotetext{
${ }^{8}$ NETO, Alcino Leite. “Pão e jornais para todo mundo”. Folha Online. 05/04/2002
} 
em comunicações, as perguntas do artigo de Leite Neto voltaram à tona. Daí, ter como tema de minha dissertação os jornais gratuitos foi algo natural. No início, minha intenção era justamente verificar se os prognósticos do artigo teriam ou não se tornado realidade. Mas ainda sentia falta de um foco mais bem definido. Ainda no primeiro semestre do mestrado, cursei a disciplina "Propaganda, Identidade e Discurso (CRP-5123)”, oferecida pelo Prof. Dr. Eneus Trindade Barreto Filho. Originalmente, tal disciplina não estava entre meus planos. Eu a procurei por indicação de um amigo, o então mestrando (hoje já mestre e doutorando) Ivan Paganotti, que em uma conversa certa vez me disse que a linha de pesquisa do Prof. Eneus Trindade poderia me dar suporte para fazer associações entre a identidade dos jornais gratuitos modernos e o tipo de anúncio publicitário veiculado em suas páginas. No trabalho final da disciplina, utilizei quatro anúncios divulgados no jornal Destak para fazer uma análise interdiscursiva entre jornalismo e publicidade. Logo percebi que o estudo ao qual eu estava me dedicando não poderia deixar de contemplar o aspecto publicitário na lógica de produção de sentido desse veículo midiático. O grau de imbricação jornalismo x publicidade dos gratuitos modernos era de outra ordem na comparação com um jornal pago convencional. Os conceitos de gêneros discursivos e de análise interdiscursiva expostos na disciplina mostraram-se extremamente valiosos para explicar o fenômeno. A partir dali, passei a julgar que este poderia ser o eixo da dissertação, sem deixar, no entanto, de abordar ao longo dela as discussões que me motivaram inicialmente a buscar o mestrado e as possíveis respostas às previsões feitas por Leite Neto em 2002.

\section{Apresentação dos capítulos:}

Feita a introdução (capítulo 1) sobre os aspectos mais gerais e as motivações do autor para este trabalho, faz-se útil apresentar a divisão temática que será empregada para facilitar a abordagem sobre a relação entre o modo de produção dos jornais gratuitos modernos e sua relação com o discurso publicitário a partir das análises de capas desses veículos.

Os aspectos formais desta dissertação serão o objeto da primeira parte. Dentro dela, o segundo capítulo (considerando a introdução como primeiro capítulo) tem como objetivo descrever a metodologia a ser adotada. Será feita uma descrição do objeto da pesquisa, do corpus selecionado para a análise e os fundamentos teóricos aplicados nela. O autor pretende, a partir disso, verificar como os gratuitos modernos intensificaram o imbricamento entre os diversos gêneros discursivos pertencentes ao jornalismo e à publicidade, especialmente sob a temática comum do entretenimento. O capítulo em questão abordará os conceitos de dialogia e de gêneros de discurso. Haverá um histórico sobre a instituição do gênero jornalístico, do 
gênero publicitário e, em seguida, quais mecanismos levaram a uma constante intersecção entre esses gêneros, chegando ao exemplo desse imbricamento nos jornais gratuitos modernos, o veículo midiático onde este fenômeno ganhou contornos até então ainda não vistos no mercado brasileiro, como argumentará esta pesquisa.

Ainda na primeira parte deste trabalho, pretendemos apresentar um referencial histórico, conceitual e contextual de nosso tema. Dentro dele, exporemos os diferentes conceitos de ethos, desde a retórica de Aristóteles até sua reconfiguração pelos principais nomes da Análise de Discurso francesa (Pechêux, Maingueneau, e Charaudeau). Tal contextualização teórica será utilizada para discutir que espaço dos geradores de discurso da mídia impressa Metro e Destak tentam ocupar. Valendo-se de um termo de Maingueneau (2008, p.98), o capítulo tentará mostrar qual tom os gratuitos modernos buscam transparecer a seu público-alvo na busca por diferenciação em relação aos demais veículos já estabelecidos há muito mais tempo no Brasil. Por fim, faremos uma discussão sobre como a mídia paga tradicional reage ao ingresso de diários gratuitos em seu mercado, tomando como base modelos de estudiosos e a situação concreta do Brasil.

Na segunda parte da pesquisa, o quarto capítulo se destina à análise interdiscursiva dos anúncios publicados nas capas dos jornais gratuitos. É necessário ressalvar que não serão objeto de análise todos os anúncios de capa do recorte temporal proposto por esta pesquisa $\left(1^{\circ}\right.$ de janeiro a 31 de março de 2011), mas sim aqueles em que há algum elemento de hibridização entre as linguagens jornalística e publicitária. A seguir, serão avaliados os anúncios presentes nas capas do jornal Folha de S. Paulo durante o mesmo período. Na sequência, serão apresentados casos relevantes de interdiscursividade em anúncios publicitários situados temporalmente fora do recorte da pesquisa. Parte deles foi coletada durante as aulas da disciplina do Prof. Eneus Trindade, em 2009, e o restante foi selecionado pelo autor após março deste ano, por julgar que eram exemplos bastante representativos para o corpus. Em seguida, será feita uma análise de chamadas de capa de Metro e Destak em que há um forte elemento publicitário, embora não se trate propriamente de um anúncio em si.

Na terceira parte da pesquisa, o espaço das considerações finais é destinado a ressaltar, com base nas observações feitas sobre os anúncios publicitários selecionados no corpus, como se dá a hibridização entre jornalismo e publicidade nos jornais gratuitos modernos e como eles intensificaram esse fenômeno de uma maneira que não se observava até então no segmento impresso no Brasil. Também é feita uma breve reflexão sobre o espaço ocupado pelos gratuitos dentro do mercado jornalístico brasileiro e como está atualmente a convivência entre eles e os jornais pagos convencionais. 


\section{METODOLOGIA}

Este capítulo busca fazer, primeiramente, uma diferenciação entre o objeto da pesquisa e o corpus selecionado para a análise. Evidentemente há pontos de intersecção entre ambos, mas é importante situá-los em círculos distintos para mostrar como os referenciais históricos e conceituais do objeto - a saber, os pontos de contato entre linguagem jornalística e publicitária e sua hibridização dentro do campo do discurso - dão suporte teórico a um olhar mais fundamentado sobre o que este trabalho pretende se debruçar: o modo de operação do discurso publicitário dos jornais gratuitos modernos por meio de suas capas.

Convém aqui citar a diferenciação feita por Lopes entre metodologia da pesquisa e metodologia na pesquisa. A primeira, também conhecida como teoria metodológica, se encontra no terreno do paradigma, que "fornece tanto modelos teóricos (determinada concepção do social), como modelos metodológicos (determinada concepção de investigação do social)” (LOPES, 2003, p. 93). A segunda, chamada de prática metodológica, "se situa no plano da prática e indica os métodos efetivamente usados numa pesquisa” (Id., ibid., p. 94).

Entendemos que o arcabouço teórico mais apropriado para estabelecer as bases tanto de nossa metodologia da pesquisa quanto da metodologia na pesquisa esteja contemplado pela Análise de Discurso (AD), por ser "especialmente produtiva para dois tipos de estudo no jornalismo: mapeamento das vozes e identificação dos sentidos” (BENETTI, 2010, p. 107). A $\mathrm{AD}$ vai acabar por romper a lógica advinda da semiótica de estudar uma mensagem textual em si, como peça una. Dado que o jornalismo constrói sentidos sobre a realidade e tem um intrínseco caráter polifônico, na acepção bakhtiniana do termo, é natural vislumbrar na AD um método útil para determinar quais são esses sentidos e de que forma outras "vozes”, entre as quais a publicitária, estão inseridas nessa multiplicidade de discursos.

A identificação dessas vozes nem sempre é possível de ser feita levando-se em conta apenas o que se pode apreender do âmbito da mensagem textual. É preciso entender que as marcas de um determinado tipo de discurso estão ali presentes porque há "formações ideológicas que, existindo anterior e exteriormente ao objeto pesquisado, acabaram por determinar aquelas formações discursivas identificadas no texto” (Id., ibid., p. 113). Se, por exemplo, algum veículo faz reiteradas críticas a um governo de orientação conservadora, é importante pesquisar quais são as diretrizes políticas que guiam essa publicação. No caso específico de nossa pesquisa, que busca detectar os elementos do discurso publicitário inseridos e hibridizados na linguagem jornalística, convém entender por que os diários gratuitos modernos trazem consigo uma forte vinculação com o mundo da publicidade. Para 
tanto, vamos também nos valer do conceito de ethos, desde sua definição clássica, oriunda da retórica de Aristóteles, até a sua readequação dentro da lógica da $\mathrm{AD}$ por parte de Dominique Maingueneau (2008). A ideia de ethos não nos é útil apenas para circunscrever a imagem que os gratuitos modernos querem associar a si mesmos perante seu público-alvo, mas também, por extensão, para analisar como essa imagem se vê refletida no estilo dos anúncios publicitários inseridos nessas publicações.

\subsection{OBJETO DA PESQUISA: O DISCURSO PUBLIJORNALÍSTICO}

O que faz uma pessoa saber diferenciar, diante de uma folha de jornal, de um aparelho de televisão ou de um rádio (enfim, diante de qualquer canal utilizado por um enunciador para transmitir determinado enunciado), uma mensagem com conteúdo jornalístico de outra com teor publicitário? Se tal pergunta fosse feita a um leitor/telespectador/ouvinte comum, provavelmente ele responderia com alguma explicação simples, tal como: “Uma notícia é um texto feito para informar e um anúncio busca nos convencer a comprar algum produto.” Não deixa de ser um critério útil para a maioria dos casos, mas muito superficial em relação ao que nos propomos a discutir neste trabalho. Mesmo sem conseguir externar o raciocínio, uma pessoa que nos dá essa resposta está, de alguma maneira, reconhecendo que ali há dois tipos de enunciado com estruturas distintas e com características internas mais ou menos constantes, que a permitem fazer uma diferenciação imediata.

O escopo desta pesquisa trata, porém, justamente de exemplos da mídia impressa em que essa distinção está longe de ser bem delineada. Como se poderá ver mais adiante no corpus da análise, os gratuitos Metro e Destak publicam em suas capas anúncios em que a intersecção com o que habitualmente identificamos como conteúdo noticioso confunde o leitor menos atento. Isto só é possível porque estes veículos operam de uma maneira híbrida com fundamentos tanto do campo jornalístico quanto do publicitário. A intenção é exatamente provocar uma sensação de estranhamento, em que se dificulta a determinação de fronteiras entre cada um dos campos. Desta maneira, o veículo em questão busca provocar a curiosidade do leitor e fazer com que ele volte sua atenção para ambas as mensagens ali presentes. Para entender como funciona esse mecanismo de mescla entre duas linguagens aparentemente tão fáceis de ser diferenciadas, é necessário apresentar o conceito de gênero de discurso, o que será feito nas páginas seguintes. Na sequência, serão expostos os argumentos que mostram por que há mais pontos de convergência do que de divergência entre jornalismo e publicidade 
e como isso leva à criação de um elemento híbrido, ao qual chamaremos de discurso publijornalístico.

\subsection{TEORIA METODOLÓGICA - GÊNEROS DE DISCURSO E}

\section{INTERDISCURSO}

Um dos conceitos-chave desta pesquisa advém dos estudos do linguista russo Mikhail Bakhtin (1895-1975). A ele se deve a ideia de que cada enunciado está sempre inserido em alguma esfera específica de comunicação. Ou seja, uma reunião de trabalho é uma esfera bastante diferente de um encontro entre amigos. Cada uma dessas situações requer distintas formas de utilização da língua, às quais se supõe que os falantes estejam adaptados. E esse uso circunscrito da linguagem tende a desenvolver "tipos relativamente estáveis de enunciados” (BAKHTIN, 2003, p. 279), que serão chamados por ele de gêneros do discurso.

Para Bakhtin, a importância do conceito de gênero do discurso se reflete no reconhecimento quase automático de um determinado tipo de enunciado quando inserido em uma lógica mais ou menos constante do uso da língua. Tomemos como exemplo a divulgação de notícias extraordinárias por meio do Plantão da TV Globo. A combinação de uma já conhecida vinheta sonora com a palavra "PLANTÃO” em maiúsculas, introduzida no meio de qualquer outro programa da emissora, nos deixa imediatamente preparados para um discurso jornalístico de caráter supostamente relevante. Já estamos adaptados à forma como está organizado este discurso em questão e esperamos dele uma constância criada pela própria maneira como ele repetidamente opera. Isso porque "nós aprendemos a moldar nosso discurso em forma de gêneros e, quando ouvimos o discurso alheio, já adivinhamos o seu gênero pelas primeiras palavras” (Id., ibid., p. 283). Ocorre aí, portanto, uma economia cognitiva na comunicação.

Se os gêneros do discurso não existissem e não tivéssemos o domínio deles e fôssemos obrigados a inventá-los a cada vez no processo da fala; se fôssemos obrigados a construir cada um de nossos enunciados, a troca verbal seria impossível’. (Id., ibid, p. 302)

Como um desdobramento dessa linha teórica, Bakthin acaba por se chocar frontalmente com a linguística do suíço Ferdinand de Saussure (1857-1913). Exatamente por definir os gêneros do discurso como tipos relativamente estáveis de enunciados, sem os quais o falante teria de despender de muito mais tempo para se fazer entender em um processo comunicacional, Bakhtin vê neles um certo valor normativo para o falante, apesar de suas 
múltiplas possibilidades de arranjos (o que veremos mais adiante). Destarte, o enunciado não pode ser considerado uma “combinação absolutamente livre das formas da língua” (Id., ibid., p. 304), tal como se podia depreender dos fundamentos da teoria saussureana, segundo a qual o enunciado (fala) é um

(...) ato individual de vontade e de inteligência, no qual convém distinguir: 1) as combinações pelas quais o sujeito falante utiliza o código da língua a fim de expressar seu pensamento pessoal; 2) o mecanismo psicofísico que lhe permite exteriorizar essas combinações (SAUSSURE, 2006, p. 22)

Bakhtin divide os gêneros do discurso basicamente em dois: gêneros primários e gêneros secundários. Essa divisão, que tem sua origem nos estudos do linguista sobre o romance literário, parte do princípio de que há gêneros mais complexos que, em sua natureza, aglutinam e remodelam gêneros mais simples, oriundos da comunicação oral imediata. Tal concepção deriva da relação entre ideologia do cotidiano (psicologia social) e sistemas ideológicos (BAKHTIN, 1997). Ele se vale da teoria de outro russo, Plekhânov, que bebe de Marx para situar "a psicologia do corpo social enquanto elo intermediário entre a infraestrutura e a super-estrutura” (GRILLO, 2008, p. 61). De forma muito clara, Volochinov transpõe o conceito da psicologia de corpo social de Plekhânov para a delimitação dos distintos tipos de comunicação social, passando pela comunicação na produção (nas fábricas, oficinas), pela comunicação de negócios, a comunicação do dia a dia (nas ruas, nos bares, nas casas), até o que ele chama de comunicação ideológica, que vem a ser o discurso da propaganda, o científico, o escolar etc.

Bakhtin via no romance uma grande capacidade de absorção e reconstrução de diversos gêneros, de tal forma que conseguia trazer para mais perto da realidade do povo os sistemas ideológicos por meio da incorporação da linguagem cotidiana e de temas populares em tramas sobre problemas mais complexos, situados no campo da super-estrutura (se tomada a terminologia marxista). Daí advém o contexto para diferenciar os gêneros primários dos secundários.

Os gêneros discursivos secundários (complexos - romances, dramas, pesquisas científicas de toda espécie, os grandes gêneros publicísticos, etc.) surgem nas condições de um convívio cultural mais complexo e relativamente muito desenvolvido e organizado (predominantemente o escrito) - artístico, científico, sociopolítico, etc. No processo de sua formação eles incorporam e reelaboram diversos gêneros primários (simples), que se formaram nas condições da comunicação discursiva imediata. Esses gêneros primários, que integram os complexos, aí se transformam e adquirem um caráter especial: perdem o vínculo imediato com a realidade concreta e os 
enunciados alheios: por exemplo, a réplica do diálogo cotidiano ou da carta no romance, ao manterem a sua forma e o significado cotidiano apenas no plano do conteúdo romanesco, integram a realidade concreta apenas através do conjunto do romance, ou seja, como acontecimento artístico-literário e não da vida cotidiana. No seu conjunto, o romance é um enunciado, como a réplica do diálogo cotidiano ou uma carta privada (ele tem a mesma natureza dessas duas), mas à diferença deles é um enunciado secundário (complexo). (BAKHTIN apud GRILLO, 2008, pp. 67-68)

O trecho acima remete a outro conceito importante da teoria bakhtiniana para esta pesquisa: o dialogismo, que, na definição de Grillo,

(...) marca a especificidade do Círculo de Bakhtin na incorporação das diferentes influências teóricas: marxismo, filosofia da vida, formalismo. Ele coloca no centro das investigações o caráter dinâmico da linguagem, que ultrapassa e, ao mesmo tempo, abarca a legítima formalização do objeto da Lingüística: a língua. Esse princípio dialógico da linguagem se exprime, de modo mais nítido, nos gêneros primários que se constituem majoritariamente dos gêneros do diálogo oral. A língua escrita e os gêneros secundários absorvem os gêneros primários, de onde a presença mais ou menos marcada da dialogização nos gêneros secundários. Portanto, a relação entre os gêneros primários e secundários permite a explicitação do princípio dialógico da linguagem, que permaneceria dissimulado se o estudo dos gêneros se concentrasse exclusivamente sobre os gêneros secundários. (Id., ibid., p. 68)

A partir desse raciocínio, constata-se que a enunciação, ainda que realizada sem a presença física de um destinatário, é marcada por um constante dialogismo, isto é, uma troca com outros enunciadores, virtuais ou reais. No ato da enunciação está sempre implícita a presença de uma outra instância enunciativa à qual se reporta o enunciador.

Esse dialogismo não opera somente na relação entre enunciador e coenunciador. Também o faz, como se infere do próprio conceito de gênero primário e secundário, na “conversa” entre diferentes gêneros. Convém aqui introduzir outro conceito bakhtiniano, o de plurilinguismo, que vem a ser o imbricamento de diversas linguagens, criando um efeito de polifonia, isto é, de múltiplas vozes se fazendo presentes em uma mesma mesnagem. O centro dessa teoria repousa na ideia de que nenhum discurso é uno e estanque. Isso representa um claro distanciamento de Bakthin em relação à corrente estruturalista simbolizada pelo legado de Saussure, que se atinha especificamente às combinações linguísticas dentro do discurso. Segundo Bakhtin, 
Todo e qualquer discurso guarda em si algum tipo de diálogo com algo que já foi dito, isto é, uma reapropriação de discursos anteriores. E essas conexões geralmente deixam rastros de heterogeneidade, detectáveis na forma como o discurso do outro é inserido (AUTHIER-REVUZ, 1990).

Os fundamentos teóricos do Círculo de Bakhtin foram posteriormente reapropriados e assimilados sob uma nova ótica por uma corrente de pensadores franceses da Análise de Discurso (AD). Nesta pesquisa vamos nos ater principalmente aos conceitos de Dominique Maingueneau, um dos expoentes desse grupo. Maingueneau vai estabelecer uma releitura do conceito de gêneros de discurso, definindo-os como "dispositivos de comunicação que só podem aparecer quando certas condições sócio-históricas estão presentes” (2008, p. 61). Há, nesse ponto, uma diferença em relação ao entendimento bakhtiniano de gênero. Para Bakhtin, “o interlocutor deve pressupor características de seu interlocutor-modelo antes de construir seu discurso por meio de determinado gênero” (GRILLO; VELOSO, 2008, p. 240). O gênero é, portanto, uma categoria discursiva, e não textual, porque envolve uma relação ativa entre enunciador e coenunciador.

(...)O direcionamento, o endereçamento do enunciado é sua peculiaridade constitutiva, sem a qual não há nem pode haver enunciado. As várias formas típicas de tal direcionamento e as diferentes concepções típicas de destinatários são peculiaridades constitutivas e determinantes dos vários gêneros do discurso. (...) A escolha de todos os recursos linguísticos é feita pelo falante sob maior ou menor influência do destinatário e da sua resposta antecipada (BAKHTIN apud SOBRAL, 2009, p. 173)

Por sua vez, Maingueneau delimita a ocorrência de um gênero de discurso de acordo com “papéis” que os interlocutores devem assumir em uma situação de comunicação específica. Ele utiliza como exemplo a circunstância em que um policial intervém por se esperar dele, nesse contexto, o papel de agente da ordem pública, e não de um simples pai de família (MAINGUENEAU, 2008, p. 70). Todo gênero de discurso, pela teoria de Maingueneau, exige dos que dele participam a aceitação de um certo número de regras mutuamente conhecidas. Pela proximidade conceitual, é interessante apresentar também a ideia de formação discursiva (FD), isto é, “uma espécie de região de sentidos (grifos da autora), circunscrita por um limite interpretativo que exclui o que invalidaria aquele sentido este segundo sentido, por sua vez, constituiria uma segunda FD” (BENETTI, 2010, p. 112). Ou ainda, pela definição clássica da AD, 
Chamaremos, então, formação discursiva aquilo que, numa formação ideológica dada, isto é, a partir de uma posição dada numa conjuntura dada, determinada pelo estado da luta de classes, determina o que pode e deve ser dito (articulado sob a forma de uma arenga, de um sermão, de um panfleto, de uma exposição, de um programa etc). (PÊCHEUX apud BENETTI, 2010, p. 112)

Voltemos a Maingueneau: ele divide os gêneros do discurso entre instituídos e conversacionais. Estes últimos operam por meio de estratégias de negociação entre os interlocutores, o que, de certa forma, os aproxima do conceito de gênero primário de Bakhtin, explicado anteriormente. Já os gêneros instituídos se dividem em quatro (GRILLO; VELLOSO, 2008, p. 243), conforme a tabela a seguir:

Tabela 2.2.1 - Gêneros de discurso instituídos, de Dominique Maingueneau

\begin{tabular}{|c|c|c|}
\hline Tipo de gênero instituído & Características & Exemplos \\
\hline Tipo 1 & $\begin{array}{l}\text { Não aceita variação ou somente } \\
\text { algumas poucas. Os interlocutores } \\
\text { obedecem às regras impostas }\end{array}$ & Carta comercial, lista telefônica \\
\hline Tipo 2 & $\begin{array}{l}\text { Os interlocutores podem produzir } \\
\text { mensagens individualizadas, mas } \\
\text { dentro de normas implícitas }\end{array}$ & Telejornal, notícia de fait-divers \\
\hline Tipo 3 & $\begin{array}{c}\text { Não existe uma cenografia } \\
\text { pré-acordada }\end{array}$ & $\begin{array}{c}\text { Anúncios publicitários, programas } \\
\text { de TV em geral }\end{array}$ \\
\hline Tipo 4 & $\begin{array}{l}\text { Autoral, em que se espera do } \\
\text { próprio interlocutor que não se } \\
\text { limite a um modelo }\end{array}$ & Romance literário \\
\hline
\end{tabular}

Embora esta pesquisa não vá se aprofundar na linha teórica de Patrick Charaudeau, outro integrante da corrente francesa da $A D$, convém expor sua classificação dos gêneros de discurso de informação. Charaudeau (2010) propõe definir o gênero de informação midiática a partir do cruzamento entre um tipo de instância enunciativa, um tipo de modo discursivo, um tipo de conteúdo e um tipo de dispositivo. A saber:

$\underline{\text { Instância enunciativa }} \rightarrow$ caracteriza-se pela origem do sujeito falante e seu grau de implicação. A origem pode estar na própria mídia (jornalista) ou fora dela (um político, um especialista)

$\underline{\text { Modo discursivo }} \rightarrow$ divide-se em acontecimento relatado (reportagem), acontecimento comentado (editorial) e acontecimento provocado (debate)

$\underline{\text { Conteúdo }} \rightarrow$ o macrodomínio abordado pela notícia em questão. Em termos práticos, seriam as editorias de um jornal impresso, como política, sociedade, cultura, esportes etc)

$\underline{\text { Dispositivo }} \rightarrow$ o suporte midiático utilizado para divulgar a informação (imprensa, rádio, TV etc) 
Estabelecida a discussão sobre os gêneros de discurso, a pesquisa se volta agora para a noção de interdiscurso, que deve muito à ideia advinda da teoria de Bakhtin de que toda linguagem é dialógica e que o dialogismo deve ser levado em conta em duas esferas, a da relação entre sujeitos e da relação entre discursos (BRAIT, 1997). É a partir do interdiscurso que um discurso se estabelece, e não o contrário. O discurso só passa a ter sentido quando situado dentro de um universo de outros discursos, e cada gênero discursivo aborda de maneira singular as múltiplas relações interdiscursivas. Como diz Maingueneau (2008, p. 56), "um manual de filosofia não cita da mesma maneira, nem cita as mesmas fontes que um promotor de venda promocional”. O interdiscurso, portanto,

(...) consiste em um processo de reconfiguração incessante, no qual uma formação discursiva é levada (...) a incorporar elementos pré-construídos, produzidos fora dela, com eles provocando sua redefinição e redirecionamento (...)” (COURTINE apud MAINGUENEAU, 1989, p. 113)

Maingueneau e Charaudeau (2004) conceituam o interdiscurso tanto num sentido mais restrito - conjunto de discursos de uma mesma área que possuem relações recíprocas de delimitação - como numa abordagem mais ampliada - conjunto de unidades de discurso com as quais um determinado discurso entra em relação direta ou indireta. Um desdobramento é a ideia do primado do interdiscurso. Possenti afirma que

(...) tal primado implica que uma formação discursiva produz o assujeitamento do sujeito na medida em que cada FD é dominada pelo interdiscurso e exclui que sejam colocadas em contraste FDs consideradas independentemente umas das outras (POSSENTI, 2003, p. 254)

O interdiscurso, dentro da toeria de Maingueneau, se divide em três camadas de profundidade, a saber: universo discursivo, campo discursivo e espaço discursivo. O primeiro faz referência ao todo das FDs, de qualquer espécie, que interagem em uma certa conjuntura. É necessariamente finito, apesar de não poder ser delimitado na prática. Em suma, serve apenas como uma referência um tanto vaga para que, a partir dela, possam ser estabelecidos os campos discursivos. Estes, por sua vez, vêm a ser o conjunto de FDs que se delimitam reciprocamente dentro de um universo discursivo. Podem tanto manter uma relação de conflito como de complementaridade. Dentro dessa compreensão, a filosofia ou a política, por exemplo, seriam campos discursivos. Um exemplo seriam as diferentes escolas filosóficas ou as correntes políticas que se defrontam na busca pelo máximo de legitimidade enunciativa 
(CHARAUDEAU; MAINGUENEAU, 2004, p. 91). É no interior deles que os discursos ganham forma.

No último nível da tríade, os espaços discursivos são os subconjuntos de FDs com os quais o pesquisador vai trabalhar para um determinado interesse. São, portanto, objeto de uma formulação específica, mas sob a condição de que haja um conhecimento dos textos que os constituem e de um saber histórico bem fundamentado. O espaço discursivo funciona, então, como o recorte por excelência do pesquisador para determinar a correlação entre duas FDs. No caso de nossa pesquisa, a incorporação de elementos jornalísticos em anúncios publicitários, bem como a identificação de marcas da linguagem da publicidade em chamadas de capa dos gratuitos, produz um interdiscurso que será diferente de outro que venha a assimilar “elementos pré-construídos” da linguagem do cinema ou da literatura.

Como veremos adiante na análise dos anúncios publicitários, alguns casos de intertextualidade serão mencionados. Portanto, é importante delimitar esse conceito em relação ao interdiscurso, embora guardem relação entre si. O próprio Maingueneau (2008) trata dessa diferenciação dentro da $\mathrm{AD}$ ao dizer que o interdiscurso é um conjunto de gêneros e tipos de discurso que interagem em certa conjuntura e que, por seu turno, o intertexto, objeto da intertextualidade, é o conjunto de textos com os quais um texto particular entra em relação. Ou, como diz Ferrara (1986, p. 93), “(...) o intertexto é o diálogo que se produz entre o dentro e o fora, o interno e o externo, entre um texto e outro texto, entre um segundo e um primeiro, entre o presente e o passado”. A ideia de intertextualidade veio de Julia Kristeva, que de certa forma reconstruiu o anterior conceito de dialogismo de Bakhtin.

(...)A noção de dialogismo - escrita em que se lê o outro, o discurso do outro - remete a outra, explicitada por Kristeva (1969) ao sugerir que Bakhtin, ao falar de duas vozes coexistindo num texto, isto é, de um texto como atração e rejeição, resgate e repelência de outros textos, teria apresentado a idéia de intertextualidade. (BARROS; FIORIN, 1999, p. 50)

A intertextualidade pode se manifestar em um determinado texto de três maneiras: pela citação, pela alusão e pela estilização. A primeira, tal como o próprio nome sugere, se dá de forma direta, como no caso de algum anúncio publicitário que mencione um personagem do cinema. Já a alusão insere, de modo indireto, uma ideia de um discurso já dito e identificável pelo coenunciador. Finalmente, a estilização reproduz elementos de um discurso existente com outra roupagem, em geral crítica. Falamos basicamente, aqui, da paródia. 
Ainda nesta seara, faz-se útil retomar o que já foi dito neste capítulo sobre os rastros de heterogeneidade deixados por um texto. Tal heterogeneidade (ou dialogia) pode ser constitutiva ou marcada. No primeiro caso, trata-se da existência de discursos prévios ancorados em um enunciado que não expõe essas bases de maneira visível. Já a heterogeneidade marcada torna aparente a presença de um outro discurso e quebra a ideia de unicidade, seja por meio do uso do discurso direto, das aspas, de remissões etc. Assim, conclui-se que toda a dialogia é constitutiva, mas não necessariamente marcada.

\subsubsection{O ETHOS - DE ARISTÓTELES À ANÁLISE DO DISCURSO}

Dentre todos os filósofos gregos da antiguidade que se ocuparam em estudar a retórica, Aristóteles foi talvez o que mais tenha se afastado dos outros por enxergar no ethos (valor, caráter) a mais relevante dentre as três provas engendradas pelo discurso, suplantando o logos (saber) e o pathos (paixão, empatia) - nesse caso, convém ressaltar que “discurso” não é uma referência ao conceito que discutimos nos capítulos anteriores, mas sim ao contexto retórico da Grécia antiga, de um orador tomar a palavra diante de uma plateia. Entendia-se como ethos a construção de uma imagem de si destinada a garantir o sucesso do empreendimento oratório. Para Aristóteles, um orador saberá convencer melhor seu público se mostrar em seu discurso um caráter honesto, entre outras qualidades ligadas à moral.

\footnotetext{
Os oradores inspiram confiança por três razões que são, de fato, as que, além das demonstrações (apódeixis), determinam nossa convicção: (a) prudência/sabedoria prática (phrónesis), (b) virtude (areté) e (c) benevolência (eúnoia). Os oradores enganam (...) por todas essas razões ou por uma delas: sem prudência, se sua opinião não é correta ou, se pensando corretamente, não dizem - por causa de sua maldade - o que pensam; ou, prudentes e honestos (epieikés), não são benevolentes; razão pela qual se pode, conhecendo-se a melhor solução, não a aconselhar. Não há outros casos. (ARISTÓTELES apud EGGS, 2011, p. 32)
}

Ao mesmo tempo, lembra Eggs (2011), a noção aristotélica de ethos está vinculada também a um sentido mais neutro quando ele faz referência à héxis, que vem a ser os hábitos, os costumes. O que soa como uma aparente contradição seria, na verdade, uma complementaridade, uma vez que, "se o verdadeiro e o justo não se impõem, é porque o orador não encontrou os argumentos apropriados” (Id., ibid., p. 38). Ou, ainda, “não é preciso 'se dar a aparência' de ser honesto e sincero (...), mas apresentar-se honesto e sincero para que o verdadeiro e o justo se imponham” (Id., ibid., p. 38). Por fim, Eggs interpreta que, pelo raciocínio de Aristóteles, 
(...) não se pode realizar o ethos moral sem realizar ao mesmo tempo o ethos neutro, objetivo ou estratégico. É preciso agir e argumentar estrategicamente para poder atingir a sobriedade moral do debate. Essas duas faces do ethos constituem, portanto, dois elementos essenciais do mesmo procedimento: convencer pelo discurso. (Id., ibid., p. 39)

Seguindo na mesma linha de raciocínio,

Se se percebe um locutor como "honesto", tende-se a minimizar, e até a ignorar, o peso das contradições em seu comportamento. Se, ao contrário, ele é percebido como "hipócrita", tende-se a atribuir importância exagerada aos mínimos sinais de desonestidade. O que é assim diretamente "captado" funciona, pois, como um input pré-proposicional da "função de credibilidade”. Esse input determinaria, a cada momento da troca comunicativa, os parâmetros da dita função de credibilidade: o que, por assim dizer, a "predispõe" a interpretar os sinais recebidos (discursivos ou não discursivos) de uma certa forma, e a atribuir de preferência certos valores ao invés de outros às informações sobre o caráter suscetíveis de ser proposicionalizadas (DASCAL, 2011, pp. 64-65)

Toda essa discussão sobre ethos ganha uma nova figura - e passa a nos ser diretamente útil nesta pesquisa - quando ocorre a transposição do discurso no sentido clássico para o discurso contemplado pela AD. Quem o faz é Maingueneau. Dentre os pensadores da corrente francesa, é ele quem vai perceber, muito apropriadamente, que

(...) além da persuasão por argumentos, a noção de ethos permite, de fato, refletir sobre o processo mais geral da adesão de sujeitos a uma certa posição discursiva. O processo é particularmente evidente quando se trata de discursos como o da publicidade, da filosofia, da política etc. que diferentemente dos que têm a ver com gêneros "funcionais', como os formulários administrativos ou manuais - não têm por objetivo uma adesão imediata, mas devem conquistar um público que tem o direito de ignorá-los ou de recusá-los. Duas razões me levaram a recorrer à noção de ethos: seu laço crucial com a reflexividade enunciativa e a relação entre corpo e discurso que ela implica. É insuficiente ver a instância subjetiva que se manifesta por meio do discurso apenas como estatuto ou papel. Ela se manifesta também como "voz" e, além disso, como “corpo enunciante”, historicamente especificado e inscrito em uma situação, que sua enunciação ao mesmo tempo pressupõe e valida progressivamente. (MAINGUENEAU, 2011, pp. 69-70)

O grande mérito de Maingueneau foi avançar sobre a ideia de que o ethos não se refere exclusivamente ao jeito de se portar, de se apresentar e de falar de um enunciador ao querer ver suas palavras compreendidas e “compradas” por um público coenunciador. O conceito é válido, sim, para qualquer tipo de discurso, inclusive os escritos, entre eles o publicitário. E, nessa transposição para o textual, a corporalidade e os trejeitos do orador passam a ser chamados de tom, “que permite ao leitor construir uma representação do corpo do enunciador 
(e não, evidentemente, do corpo do autor efetivo)” (2008, p. 98). Ou seja, cada texto teria o seu tom.

A partir da compreensão de que o coenunciador molda representações do ethos do enunciador antes mesmo que ele venha a falar ou escrever um texto, Maingueneau julga adequado fazer uma distinção entre ethos discursivo e ethos pré-discursivo. O primeiro é o que guarda um vínculo direto com a teoria aristotélica, segundo a qual a confiança em quem fala deve ser fruto do "efeito do discurso, não de um juízo prévio sobre o caráter do orador” (ARISTÓTELES apud MAINGUENEAU, p. 70). O pré-discursivo está relacionado ao fato de que, por mais previamente desinformado que seja um coenunciador em relação ao caráter do enunciador, a simples constatação de que uma oratória ou um texto associados a uma certa posição ideológica já criam algum tipo de expectativa de ethos por parte deste coenunciador. Trata-se de um grande complicador para o enunciador, uma vez que

\footnotetext{
(...) o orador, ao pronunciar seu discurso, deve construir uma imagem de si que seja análoga a seu objetivo argumentativo, levando em consideração a ideia que presumivelmente o auditório projeta dele. O ethos prévio ou prédiscursivo condiciona a construção do ethos discursivo e demanda a reelaboração dos estereótipos desfavoráveis que podem diminuir a eficácia do argumento. (HADDAD, 2011, p. 148)
}

A ideia de esterótipo desempenha um papel essencial no estabelecimento do ethos. “A estereotipagem, lembremos, é a operação que consiste em pensar o real por meio de uma representação cultural preexistente, um esquema coletivo cristalizado” (AMOSSY, 2011, p. 125). O orador acaba adaptando sua apresentação de si aos esquemas coletivos que ele crê interiorizados e valorizados por seu público-alvo. Amossy (ibid., p. 127) cita um interessante exemplo de uma entrevista coletiva concedida em agosto de 1990 pelo político francês JeanMarie Le Pen, então líder da Frente Nacional, um partido de orientação xenófoba e que, no espectro político da França, é o que está mais à direita. Naquela ocasião, o Iraque de Saddam Hussein recém-invadira o vizinho Kuwait e tropas americanas e britânicas se preparavam para atacar os soldados iraquianos. Le Pen convocou a imprensa para dizer que era contra a operação dos parceiros da França. Sabedor de seu ethos prévio de líder da extrema direita, que despertava desconfiança pela sua intolerância e desprezo com os direitos de populações que não fossem os próprios franceses, Le Pen se "vestiu” de político independente (já que não ocupava nenhum cargo no governo) e preocupado com os “riscos terríveis” da guerra, para aconselhar a França a demover seus parceiros da ideia. Ele sabia que estava falando não só para seus simpatizantes da Frente Nacional, mas para o grande público, majoritariamente 
refratário às suas ideias. No caso de Le Pen, porém, a construção discursiva não foi suficiente para que o povo francês se desfizesse de seu ethos prévio.

\subsection{PRÁTICA METODOLÓGICA}

Em seu livro Análise de Textos de Comunicação, como o próprio título da obra sugere, Dominique Maingueneau apresenta vários exemplos de textos jornalísticos e publicitários e os avalia à luz de alguns conceitos da AD. Esses conceitos lhe servem de ferramenta útil para explicar o sentido das mensagens ali expostas. A nós interessa particularmente a ideia das cenas de enunciação. "Um texto não é um conjunto de signos inertes, mas o rastro deixado por um discurso em que a fala é encenada” (2008, p. 85). Ele divide as cenas de enunciação em três. A saber:

A primeira camada da cena de enunciação, chamada de cena englobante, se refere ao tipo de discurso da mensagem em questão. No nosso caso, invariavelmente estamos nos referindo ao tipo de discurso publicitário e/ou jornalístico. Pode-se dizer que este é o primeiro nível de apreensão do enunciado. Em época de eleições, quando recebemos na rua uma folha de papel em que aparecem a imagem e nome de um candidato, a dedução natural é a de que estamos diante de um tipo de discurso político, em que o enunciador da mensagem se dirige a diversos outros coenunciadores. A cena englobante é, pois, o recorte mais amplo, e também por isso insuficiente para abarcar as especificidades de um determinado enunciado.

O nível seguinte da cena de enunciação é a cena genérica. O termo decorre da sua relação direta com o conceito de gênero de discurso. Retomando o exemplo do "santinho" entregue na rua em período eleitoral, não basta ao coenunciador reconhecer aquela folha de papel como uma mensagem de cunho político, fora de uma temporalidade e de uma circunstância específicas no jogo entre enunciador e coenunciador. Por exemplo, um panfleto de um candidato ligado a causas ambientais será interpretado de maneira muito diferente de um que exponha um político vinculado ao setor empresarial. Neste nível da cena de enunciação, o conceito de ethos se aplica com bastante propriedade. O candidato "verde" da nossa situação hipotética acima descrita provavelmente será questionado pela distribuição dos panfletos na rua, pois se espera dele um compromisso com a preservação das florestas e a despoluição urbana. Como o papel dos panfletos significa o corte de árvores para sua obtenção e uma consequente sujeira ao ser descartado nas ruas, tal atitude entra em conflito com a representação que este candidato busca incutir em seu potencial eleitorado. Por sua vez, o outro concorrente, empresário, certamente não sofrerá o mesmo tipo de cobrança; afinal, 
não se tem a expectativa prévia de que ele exerça o papel de defensor da natureza, mas sim o oposto, pela própria ideia de desenvolvimento industrial em choque com o discurso preservacionista. Em suma, a cena genérica circunscreve os personagens em suas peculiaridades discursivas, tanto da parte do enunciador como do coenunciador.

Para Maingueneau, a cena englobante e a cena genérica compõem o chamado quadro cênico de qualquer texto. "É ele que define o espaço estável no interior do qual o enunciado adquire sentido - o espaço do tipo e do gênero de discurso” (ibid., p. 87). Embora seja importante para a compreensão da mensagem, o quadro cênico não é o componente da enunciação com o qual o enunciador vai se deparar diretamente. Aí se introduz o terceiro e último nível da cena de enunciação, a cenografia. Em uma definição simples, trata-se dos elementos textuais e imagéticos presentes na cena, que vão ajudar a legitimá-la como tal. Mais uma vez utilizando nosso exemplo dos panfletos eleitorais, a cenografia do candidatoempresário poderia ser um escritório com uma mesa de reuniões em cuja ponta ele está sentado e conversando com outros engravatados, que ao mesmo tempo fazem anotações e parecem prestar atenção em suas palavras. A construção cênica tenta, pois, reforçar a ideia de que se está diante de um homem acostumado a tomar grandes decisões e ser respeitado por sua iniciativa; por isso, diante de quem seria apto também a decidir o que é melhor para a população em um cargo público.

\footnotetext{
Desse modo, a cenografia é ao mesmo tempo a fonte do discurso e aquilo que ele engendra; ela legitima um enunciado que, por sua vez, deve legitimá-la, estabelecendo que essa cenografia onde nasce a fala é precisamente $a$ cenografia exigida para enunciar como convém, segundo o caso, a política, a filosofia, a ciência, ou para promover certa mercadoria... (ibid., pp. 87-88)
}

Maingueneau traz um exemplo bastante didático de como aplicar a metodologia das cenas de enunciação em um anúncio publicitário. Trata-se da propaganda de um chá emagracedor, veiculada em uma revista feminina francesa. Infelizmente, a edição de que dispomos do livro Análise de Textos de Comunicação não reproduz a página da revista, mas o autor a descreve em detalhes. No canto esquerdo, há uma foto em que uma jovem de terninho fala ao telefone, sentada no braço de uma cadeira de escritório. Ao lado, o seguinte texto.

Que reunião! Esses cafés da manhã de negócios, todos aqueles croissants, aqueles pãezinhos, era tanta tentação que não pude resistir... Mas eu vou dar um jeito nisso. Ao meio-dia, vou reagir. Um encontro com a boa forma: somenten WEEK-END e eu. Práticos, esses saquinhos que a gente carrega aonde vai. Sabor de baunilha ou de legumes, meus quilinhos a mais logo vão desaparecer. Os intervalos para a boa forma WEEK-END e seus cardápios equilibrados, isso conta muito na agenda de uma gulosa. (ibid., pp. 85) 
A cena englobante deste enunciado é, claramente, a de um anúncio publicitário. No segundo plano, o da cena genérica, pode-se dizer que estamos diante de uma propaganda de um produto para emagrecer, dentro de uma revista feminina. Por fim, a cenografia, ou seja, a cena que de fato estamos vendo no anúncio, a qual já foi descrita acima: uma jovem funcionária de um escritório conversa ao telefone com outra pessoa, provavelmente uma amiga pelo tom informal da conversa, e lhe relata o dia agitado que teve pela manhã e a preocupação em manter uma alimentação balanceada.

A pessoa que lê a revista, diz Maingueneau, "encontra-se simultaneamente envolvida nessas três cenas (ibid., p. 86). Na englobante, ela se inscreve como leitora de revista e como consumidora de um discurso publicitário. Na cena genérica, ela é enquadrada como alguém que também se preocupa em ter uma boa forma física. Por fim, na construída pelo texto, isto é, na cenografia, ela é tanto interlocutora como amiga da mulher ao telefone.

Este é um exemplo de anúncio com uma cenografia especificada, em que não há uma combinação de cenas (só existe uma mulher conversando informalmente com uma amiga). No entanto, a publicidade geralmente trabalha com uma cenografia difusa, que remete a diferentes gêneros de discurso. Se nesta mesma propaganda do chá emagrecedor WEEK-END houvesse um quadro alertando que o uso desse produto deve ser feito apenas mediante orientação médica, logo há uma referência a um discurso do especialista, não necessariamente ligado ao apelo do consumo. Seriam, então, dois tipos de cenografia em um mesmo anúncio.

No que diz respeito à nossa pesquisa, a divisão entre as cenas de enunciação será o eixo da análise do corpus, tanto em relação aos anúncios publicitários quanto às chamadas de capa dos jornais gratuitos modernos. Convém deixar claro, porém, que outros elementos presentes na $\mathrm{AD}$ serão empregados nesta tarefa, como os aspectos polifônicos e de interdiscurso detectáveis nos anúncios e nas chamadas de capa.

\subsection{PROCEDIMENTOS METODOLÓGICOS}

Como explicitado anteriormente, esta pesquisa está baseada nos anúncios publicitários e nas chamadas de capa do canto superior direito dos diários gratuitos Metro e Destak, no recorte temporal de $1^{\circ}$ de janeiro a 31 de março de 2011. A escolha pela capa como objeto de pesquisa principal se deve a seu caráter de síntese hierárquica de uma publicação. Afinal, ela "funciona como um grande anúncio, um convite para o enfrentamento do jornal como um 
todo. É o resumo do que o leitor passa a considerar os principais acontecimentos do dia, mesmo que ele não leia as outras páginas.” (BRAIT, 1991, pp. 86-87)

Inicialmente, ainda na fase de qualificação, a proposta era abranger um período de seis meses. Mas tanto os examinadores da banca como a orientadora deste trabalho sugeriram diminuir o recorte, sob o argumento de que o material de análise seria demasiadamente extenso e de que seria possível chegar à comprovação de nossa hipótese com um período menor. Desta forma, optou-se pela redução à metade. A coleta do corpus foi feita por meio de pesquisa no acervo virtual de ambos os gratuitos (http://www.destakjornal.com.br e http://www.publimetro.band.com.br) e do diário pago tradicional Folha de S. Paulo (http://www.uol.com.br/fsp), cujas capas servirão à pesquisa como efeito de comparação entre o discurso vigente na capa de um gratuito e o existente em um quality paper pago. No total, foram analisadas as capas de 60 edições do Metro, 55 do Destak e 90 da Folha que circularam nesse intervalo. Tal discrepância nos números se deve ao fato de que os diários gratuitos não circulam nos fins de semana e feriados (nesse período houve o Carnaval e o aniversário da cidade de São Paulo) e normalmente entram em recesso de início de ano. Vale lembrar ainda que o Metro tem mais edições que o Destak porque voltou a circular mais cedo em janeiro. Por sua vez, a Folha e outros jornais pagos convencionais tradicionalmente circulam todos os dias do ano, sem exceção.

A partir dessa amostragem, fez-se um segundo recorte. Com base no arcabouço metodológico da $\mathrm{AD}$, já descrito anteriormente, o critério utilizado foi o de selecionar 1) capas onde estivessem presentes anúncios publicitários que tivessem algum tipo de diálogo com o discurso jornalístico, especificamente no contexto da capa em questão, e 2) chamadas de capa do canto superior direito em que o primeiro plano de apreensão é o do discurso jornalístico, mas que possuem um forte vínculo com a linguagem publicitária - a opção pela chamada de capa nesta posição se deve ao fato de ser tradicionalmente considerado um local nobre na primeira página por sua visibilidade, pois as pesquisas de fluxo de leitura mostram que uma pessoa costuma olhar primeiro para esse espaço ao se deparar com uma folha de jornal. Desta forma, chegamos a 8 capas no recorte temporal proposto. Fora dele, selecionamos outras sete. Cinco dessas capas extras, publicadas por Destak e Metro antes de janeiro de 2011, foram objeto de análise no trabalho final da disciplina "Propaganda, Identidade e Discurso (CRP-5123)”, ministrada pelo Prof. Dr. Eneus Trindade Barreto Filho, e serão incluídas no corpus por causa de sua representatividade dentro da proposta de mostrar a hibridização jornalístico-publicitária. As outras duas capas, posteriores a março de 2011, são 
da Folha e foram escolhidas porque também trazem anúncios com uma clara interdiscursividade entre publicidade e jornalismo.

Primeiramente, serão analisados os exemplos de anúncios que trazem uma dialogia com a linguagem jornalística. Em seguida, o objeto de análise serão as chamadas de capa com apelo à publicidade do entretenimento. Em todos os casos, a reprodução das capas vem logo a seguir do texto analítico. Foram excluídos do corpus os anúncios de capa que se restringiam ao tipo de discurso publicitário, sem um diálogo com o texto jornalístico.

Como exposto no capítulo da Prática Metodológica, cada anúncio ou chamada de capa será analisado de acordo com sua cena englobante, cena genérica e cenografia. A seguir, utilizaremos a classificação "aspectos polifônicos e interdiscursividade”, tal qual foi feito na pesquisa prévia para a disciplina do Prof. Eneus Trindade. Por fim, quando julgarmos necessário, adotaremos ainda a categoria “outros comentários” para os casos em que é proveitoso citar outras fontes a respeito do anúncio em questão - como críticas ao fato de a Folha ter veiculado um anúncio de um curso de idiomas que trouxe sua capa reproduzida com textos em inglês. Nesse critério pretendemos estender nossa avaliação sobre quais fatores presentes no enunciado em questão remetem tanto à linguagem jornalística quanto à publicitária, valendo-se dos demais conceitos de AD expostos anteriormente, como intertextualidade, heterogeneidade e ethos discursivo, por exemplo. As chamadas de capa selecionadas estão todas vinculadas a uma cenografia que remete à ideia de entretenimento, pois fazem referência a filmes-animações ou seriados de grande audiência. O motivo para tal escolha ficará mais claro no próximo capítulo, "Referencial Teórico, Conceitual e Contextual”, quando tratarmos do ethos dos diários gratuitos modernos e sua íntima associação com uma sociedade de consumo, seja ele de produtos materiais ou culturais. 


\section{REFERENCIAL TEÓRICO, CONCEITUAL E CONTEXTUAL}

Como já exposto no capítulo anterior, esta pesquisa visa a apresentar argumentos que consolidem a ideia da existência de um discurso "publijornalístico" nos veículos de comunicação impressa do Brasil, mais especificamente - e notadamente - nos diários gratuitos modernos Metro e Destak. Esse processo de hibridização, porém, tem suas bases fundadas muito antes do aparecimento dessas publicações aqui analisadas. Pode-se dizer que os gratuitos se valeram de características comuns a esses dois tipos de discurso - utilizando-se aqui a terminologia proposta por Maingueneau - para otimizar sua tarefa mais primordial. E essa tarefa, que fique claro, não é a persuasão do leitor coenunciador, mas sim a busca por anunciantes.

Uma contra-argumentação possível a essa ideia repousa no fato de que jornais convencionais, como Folha de S. Paulo e O Estado de S. Paulo, também travam uma batalha para atrair o maior número de anúncios possível. Não se pode negar essa observação. Mas a simbiose entre jornalismo e publicidade é de outra dimensão nos gratuitos, pela simples e evidente razão de que, por causa da gratuidade, essas empresas jornalísticas não podem contar com a receita advinda da venda em banca e da assinatura dos exemplares. No faturamento de um jornal, é importante dizer, essa fonte de ingressos vinda do público-leitor está longe de ser a principal - estima-se que a venda de anúncios componha cerca de $80 \%$ do total das receitas. Mas $80 \%$ é uma realidade de negócio, e 100\% é outra. Aproximar-se da linguagem publicitária para aumentar seu poder de atração, nesse caso, é uma necessidade inescapável dos gratuitos.

Para entender como esses veículos operam, convém primeiramente discorrer sobre as origens do conceito de discurso publicitário e de discurso jornalístico e quais são os pontos de contato entre esses dois campos de construção de sentido que os levaram ao grau de hibridização que testemunhamos atualmente. Essa discussão será feita na próxima seção. Em seguida, vamos entender a lógica de funcionamento de um gratuito moderno e de que forma ele tenta estabelecer uma imagem de si que seja atraente ao mercado publicitário. Nesse ponto, retomaremos a noção de ethos dentro da $\mathrm{AD}$, que servirá de importante ferramenta teórica para definir o "lugar” ocupado por esses veículos na mídia impressa. 


\title{
3.1 APROXIMAÇÃO DOS DISCURSOS PUBLICITÁRIO E JORNALÍSTICO
}

Esta pesquisa não tem como ambição fazer um histórico do conceito de publicidade nem tampouco fechar questão em torno de uma definição precisa. Trata-se de um objeto de estudo muito amplo, em que diversos campos de conhecimento se entrecruzam. Dentro de nosso universo de trabalho, que são os anúncios publicitários veiculados em um suporte midiático, nos parece válida a conceituação de Barbosa (2000).

\begin{abstract}
No contexto mercadológico, cabe à publicidade informar sobre aspectos reais ou imaginários de um produto, serviço ou loja (em particular), a fim de convencer, persuadir, envolver um segmento de mercado de forma que este tenha o desejo de satisfazer suas necessidades físicas ou psíquicas por intermédio do objeto ou serviço (BARBOSA apud CASAQUI, 2000, p. 29)
\end{abstract}

A formulação é até simples, mas sintetiza de maneira muito eficiente o conhecimento comum que se tem da função da publicidade. Trata-se de um modo de construção de sentido que não necessariamente lida apenas com enunciados circunscritos no plano da realidade. $\mathrm{O}$ que importa é passar uma imagem de cumplicidade com o coenunciador, tentando validar seu discurso pela própria incorporação dos valores de quem se pretende convencer a adquirir determinada mercadoria. Desta forma,

A publicidade visa, com efeito, persuadir, associando o produto que vende a um corpo em movimento, a um estilo de vida, uma forma de habitar o mundo; como a literatura, a publicidade procura "encarnar", por meio de sua própria enunciação, aquilo que ela evoca, isto é, procura torná-lo sensível” (MAINGUENEAU, 2008, p. 109)

Convém, ainda, diferenciar o papel da publicidade em relação à propaganda. Esta tem uma vinculação com a propagação de uma ideia ou de uma corrente política, religiosa etc. Aquela, por sua vez, se enquadra como o meio de divulgação de uma informação a um público-alvo determinado. Ao contrário da propaganda, o discurso publicitário tenta sempre suavizar seu caráter persuasivo, como se não desejasse realmente que o coenunciador se deixe convencer pelos argumentos e consuma o produto em questão. Mas, no tocante às estratégias de sedução da publicidade,

(...) o fato é que a utilização estratégica de recursos estéticos e de argumentos emocionais com o intuito de seduzir o público tem efeito altamente persuasivo. O discurso publicitário utiliza, ao mesmo tempo, dois tipos de função hedônica - a função estética e a função mística - como meio e não como fim” (BIZZOCHI, 2003, p. 296) 
A fundamentação de Bizzochi de que o discurso publicitário se vale de uma função estética apenas como meio para alcançar seu objetivo primordial, e não puramente como fim, é o caminho para entender por que a publicidade se distancia da arte, seja ela qual for. Um anúncio publicitário atraente pode ser um excelente exemplo de arte gráfica - e a publicidade brasileira é uma das mais premiadas internacionalmente pela qualidade de suas peças -, mas provavelmente será desprezado pelo mercado se não incitar o público-alvo a consumir o produto em questão. Como reforçam Ivan Santo Barbosa e Vander Casaqui,

\begin{abstract}
Seu objetivo é estimular, predispor seu público-alvo ao ato de consumir, distintamente da arte, que tem o compromisso único com a própria linguagem, propondo plurissignificações, rupturas, novas ideologias, valores destoantes do senso comum, questionamentos à existência humana. Certamente a publicidade pode valer-se do discurso artístico, utilizar-se dessa linguagem como meio, como expressão. No entanto, o estético na publicidade é meio, enquanto na arte, grosso modo, coloca-se como fim nesse processo de conhecimento através dos sentidos” (BARBOSA; CASAQUI, 2000, p. 72)
\end{abstract}

Nem sempre ao longo da história, evidentemente, a publicidade operou de forma tão complexa. Nos seus primórdios de inserção nos jornais impressos, ainda no século XVII, limitava-se a apenas transmitir uma informação sobre a venda de um produto em um determinado lugar, sem nenhum elemento gráfico fora do textual. O jornal inglês Mercurius Brittanicus publicou, em 1625, um anúncio publicitário de um livro, o primeiro que se tem notícia. Seis anos depois, o francês Téophraste Renaudot abre espaço, em sua gazeta (uma nomenclatura dos jornais daquela época que acabou se consagrando ao longo dos séculos e é usada até hoje), para uma seção de anúncios (LAMPREIA, 1983, pp. 19-20). Estabelece-se, aí, uma nova fonte de receita para os jornais. Mas a consolidação da publicidade como suporte orçamentário na imprensa escrita só viria a ocorrer no século XIX, com o jornal The Times na Inglaterra e o La Presse na França. Tais publicações obtiveram um equilíbrio financeiro que lhes permitiu, primeiramente, reduzir o preço do exemplar e, assim, conseguir um públicoleitor maior. Consequentemente, com mais gente lendo o periódico, tornou-se mais fácil atrair novos anunciantes (GRILLO, 2003, p. 48). A presença dos anúncios publicitários nos noticiosos impressos é trazida para o Brasil junto com o próprio veículo em si. O primeiro jornal editado na então colônia portuguesa, a Gazeta do Rio de Janeiro, cujo número inaugural é de setembro de 1808, estampava em suas páginas um anúncio sobre a venda de um imóvel no Rio de Janeiro. Até meados do século XIX, afirmam Adam e Bonhomme (apud GRILLO, 2003), os anúncios adotavam uma configuração baseada no modelo do livro, com tipografia linear e indiferenciada. A imagem, antes apenas um elemento incluído no meio do 
texto para não deixar a leitura tão penosa, só vai ganhar destaque na publicidade no início do século XX.

Antes de nos aprofundarmos na relação entre linguagem publicitária e jornalística, fazse necessário delimitar as peculiaridades do jornalismo como construção de sentido. É conhecida a busca desse campo do conhecimento pela apreensão do mundo que nos rodeia com a maior objetividade possível. É este o contrato implícito firmado pelo profissional do jornalismo com seu público: relatar os fatos com isenção a um leitor que tire suas próprias conclusões a respeito desse assunto. Traquina (2005) cita a "teoria do espelho”, segundo a qual o jornalismo pretende operar como "espelho do mundo” e as notícias são escritas com base apenas no que a "realidade” estabelece, cabendo ao jornalista tão somente descobrir a "verdade” e descrever o que ocorreu. Utilizamos as aspas para os termos realidade e verdade por se tratar de conceitos que não se sustentam dentro da lógica comunicacional, embora estes ainda sejam os pilares que dão sustentação à credibilidade jornalística.

Como já discorremos anteriormente sobre a teoria de Bakhtin, toda a enunciação pressupõe uma dialogia, isto é, uma situação em que o enunciador modula o seu enunciado de acordo com as características do coenunciador ao qual vai se dirigir e de acordo com o tipo de efeito que ele pretende causar neste mesmo coenunciador ao formular seu discurso. Da mesma forma, por parte do leitor-coenunciador, há também uma expectativa de que o emissor da notícia cumpra algumas regras pré-estabelecidas e mutuamente conhecidas dentro dos vários gêneros de discurso presentes no jornalismo. Nesse ponto, convém recorrer à noção de contrato da enunciação, essencialmente cooperativo e regido por normas.

\begin{abstract}
Um jornalista assume o contrato implicado pelo gênero de discurso do qual participa; um fait divers, por exemplo, deve ser verídico (relatar somente a verdade), apresentar um tema adequado ao fait divers (um incêndio em um celeiro e não um acontecimento político), conter todas as informações necessárias à compreensão (cf. os famosos 'quem?', 'quando?', 'onde?'...), não pressupor quaisquer saberes que não sejam os de seu leitor-modelo etc. De forma recíproca, é natural que o leitor de um fait divers espere que sejam respeitadas essas normas que correspondem às suas expectativas em relação ao gênero.”(MAINGUENEAU, 2008, p. 69)
\end{abstract}

Logo, há um evidente traço de intersubjetividade nesse contrato. O público-alvo da mensagem jornalística é, por definição, difuso e de difícil circunscrição, mas nem por isso o jornalista produz uma notícia sem a intenção de destacar um recorte de uma determinada realidade para construir um sentido específico. Ela será lida - e entendida - dentro de um contexto específico. Portanto, o jornalismo é norteado pelas relações que se estabelecem entre a instância de produção e de recepção. 
Charaudeau aprofunda a discussão com seu modelo da máquina midiática ao determinar "três lugares de pertinência” (2010, p. 23). A primeira é a produção, incorporada pelo produtor da informação (a empresa jornalística como entidade e seus integrantes); a segunda, da recepção, diz respeito a todo e qualquer consumidor de informação (leitores, ouvintes, telespectadores); por fim, a terceira se refere ao produto, no caso o texto midiático (notícia de jornal, radiofônica, televisiva etc). E essas três instâncias, segundo Charaudeau, relacionam-se desta maneira (ibid., p. 23).

Tabela 3.1.1 - Os três lugares da máquina midiática, de Patrick Charaudeau

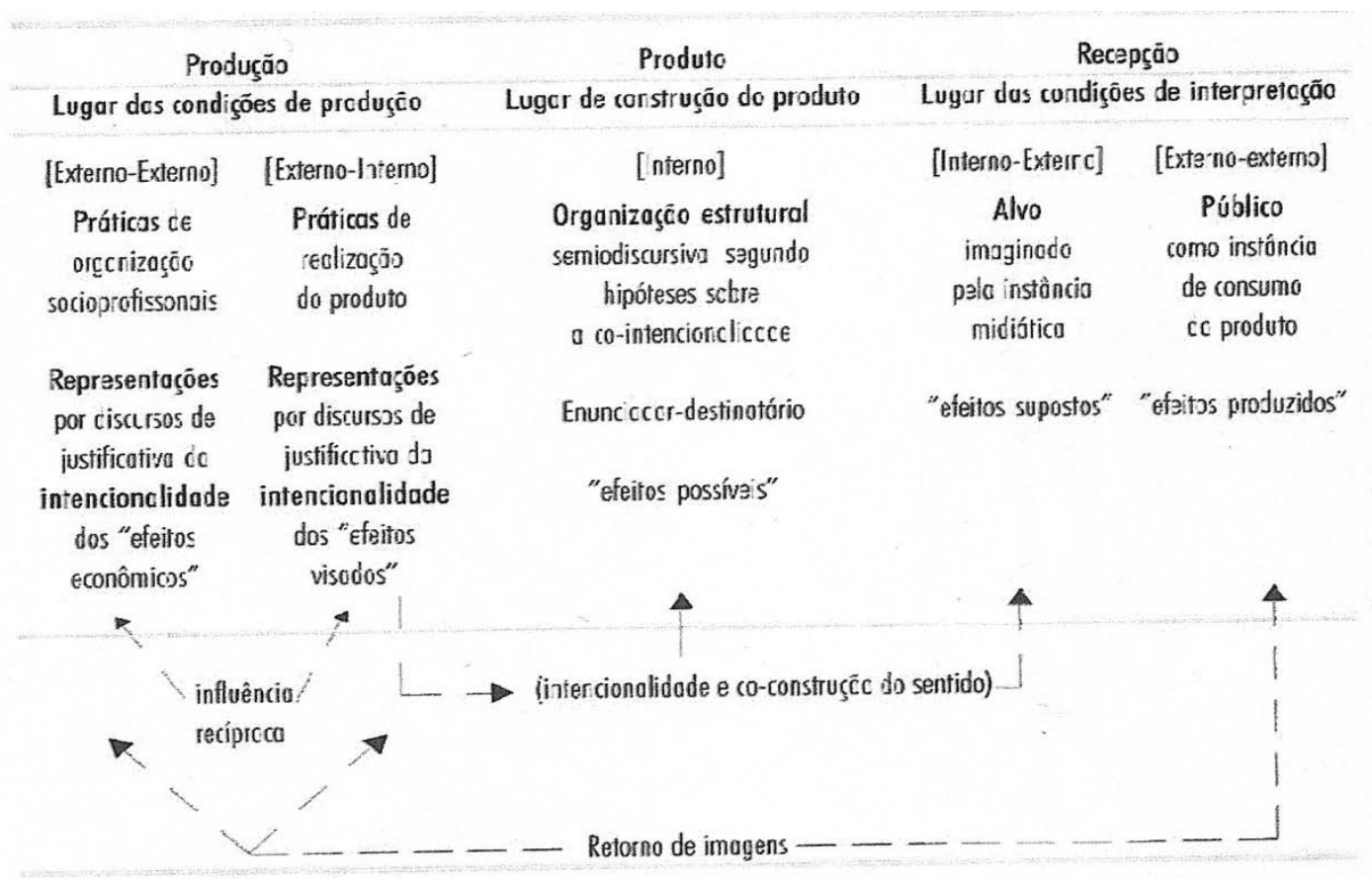

O quadro acima estabelece os mecanismos de funcionamento do fazer jornalístico. Na instância da produção, chama de espaço “externo-externo” as relações sócio-econômicas da empresa midiática, cujos representantes precisam se nortear por uma intencionalidade de “efeitos econômicos”, isto é, as decisões têm de estar voltadas à otimização dos processos de produção. O “externo-interno” se atém às práticas de realização do produto em si e seu discurso se pauta pela intencionalidade de "efeitos visados”, afinal, a empresa midiática não tem nenhuma segurança de que seu produto vai ser assimilado pelo receptor da maneira que ele pretende. É por esta razão que Charaudeau fala em “efeitos possíveis” quando se refere ao lugar de construção do produto, em que está pressuposta uma co-intencionalidade na relação enunciador-destinatário. 
A instância de recepção, por sua vez, é o lugar das condições de interpretação, ou seja, as circunstâncias segundo as quais o receptor vai assimilar o produto jornalístico. O espaço “interno-externo” diz respeito ao alvo imaginado pela empresa midiática e que, por sua própria natureza, pode gerar apenas “efeitos supostos”. No espaço “externo-externo” se encontra o público efetivo, aquele de que fato vai consumir o produto midiático - portanto, pode-se falar aí em "efeitos produzidos”.

O modelo proposto por Charaudeau apenas reforça a ideia de que há muitas variáveis presentes no jogo midiático para se dizer que o jornalismo opera no campo da objetividade. Existem o receptor imaginado pelo fazer jornalístico e o receptor real, sendo que este pode aparecer tanto no consumo em si do produto quanto na interação com a empresa midiática, seja em um telefonema para a redação ou enviando cartas e e-mails.

Tal como a questão sobre o que é publicidade, não há nesta pesquisa a intenção de se alongar em demasia em relação a uma definição de jornalismo, também um campo que permite múltiplas teorizações. Como profissional de imprensa há alguns anos, é curioso notar que o jornalista pouco ou nada se preocupa em refletir sobre o próprio trabalho. Embora não o faça, o jornalista tem um saber internalizado a respeito do que pode fazer e de quais são os mecanismos internos e externos de funcionamento da máquina midiática. Isso se deve a alguma práticas institucionalizadas na esfera da comunicação. Nesse sentido, nos parece uma boa síntese atestar que,

De forma mais ampla, o jornalismo constrói sentidos sobre a realidade, em um processo de contínua e mútua interferência. De forma mais restrita, a notícia é uma construção social que depende basicamente de seis condições de produção ou existência: a realidade, ou os aspectos manifestos dos acontecimentos; os constrangimentos impostos aos jornalistas no sistema organizacional; as narrativas que orientam o que os jornalistas escrevem; as rotinas que determinam o trabalho; os valores-notícia dos jornalistas; as identidades das fontes de informação utilizadas e seus interesses. (TRAQUINA apud BENETTI, 2010, pp. 110-111)

Expostos os principais fundamentos do discurso publicitário e do discurso jornalístico (à guisa de esclarecimento, utilizamos a nomenclatura “discurso” publicitário e/ou jornalístico como uma simplificação para os diversos gêneros discursivos englobados por esses dois tipos de discurso), faz-se oportuno colocá-los em perspectiva para identificar quais são os pontos de distanciamento e de aproximação entre ambos. No quadro da página seguinte, Grillo (2003, pp. 52-53) estabelece uma comparação entre esses dois discursos (publicitário e, no caso de seu estudo em particular, o jornalístico informativo de natureza política) no que se refere às 
condições de produção, tomando como base a imagem que o enunciador faz do coenunciador, a finalidade do discurso, a forma de estabelecer o referente e a natureza do interdiscurso.

Tabela 3.1.2 - Discurso publicitário versus discurso jornalístico

\begin{tabular}{|c|c|}
\hline Discurso publicitário & $\begin{array}{c}\text { Discurso jornalístico informativo } \\
\text { de natureza política }\end{array}$ \\
\hline $\begin{array}{l}\text { Dirige-se a grupos específicos: os grupos de } \\
\text { consumidores potenciais, identificados por } \\
\text { suas tendências sócio-econômico-culturais. }\end{array}$ & $\begin{array}{c}\text { Dirige-se a um leitor situável no tempo e no } \\
\text { espaço: o conjunto dos leitores adultos que, } \\
\text { no caso de Folha de S. Paulo e O Estado de } \\
\text { S. Paulo, provém das classes } \\
\text { média e alta urbanas. }\end{array}$ \\
\hline $\begin{array}{l}\text { Pressupõe um leitor que não exige uma } \\
\text { descrição objetiva do produto, mas admite } \\
\text { oscilações entre o mundo real e o mundo } \\
\text { imaginário proposto pela propaganda, } \\
\text { resultando obrigatoriamente numa } \\
\text { valorização positiva do produto e do } \\
\text { consumidor que o adquire. }\end{array}$ & $\begin{array}{l}\text { Pressupõe um leitor que exige a descrição } \\
\text { objetiva do mundo real, em todos os seus } \\
\text { aspectos. Com isso, os gêneros informativos } \\
\text { se fundam na divisão nítida entre o mundo } \\
\text { real e o imaginário, afastando-se deste e } \\
\text { identificando-se com aquele. }\end{array}$ \\
\hline $\begin{array}{l}\text { Duas finalidades complementares: uma } \\
\text { finalidade descritiva e informativa de } \\
\text { valorização do produto (fazer saber), e uma } \\
\text { finalidade incitativa da sua compra (fazer } \\
\text { fazer). Na maior parte das publicidades, a } \\
\text { finalidade é explicitamente constativa e } \\
\text { implicitamente incitativa. }\end{array}$ & $\begin{array}{l}\text { Também possui duas finalidades: uma } \\
\text { finalidade descritiva e informativa da } \\
\text { realidade (fazer saber), e uma finalidade de } \\
\text { captação para a compra do jornal (fazer } \\
\text { fazer). A imprensa se constitui da } \\
\text { valorização da função informativa em } \\
\text { detrimento da função comercial. }\end{array}$ \\
\hline $\begin{array}{l}\text { Estrutura semiológica híbrida: compõe-se de } \\
\text { significantes icônicos, imagens que } \\
\text { repousam sobre uma estreita proximidade } \\
\text { com o referente (produto), e significantes } \\
\text { linguísticos, de natureza arbitrária. } \\
\end{array}$ & $\begin{array}{l}\text { Estrutura semiológica híbrida: compõe-se de } \\
\text { significantes icônicos, imagens que } \\
\text { repousam sobre uma estreita proximidade } \\
\text { com o referente (real), e significantes } \\
\text { linguísticos, de natureza arbitrária. }\end{array}$ \\
\hline $\begin{array}{l}\text { Retórica do semelhante, do repetível e do } \\
\text { (re)conhecível, com vistas a se conformar ao que o } \\
\text { público ama ou quer ouvir. A } \\
\text { argumentação publicitária adapta o produto } \\
\text { às aspirações virtuais do consumidor. }\end{array}$ & $\begin{array}{l}\text { Retórica do semelhante, do repetível e do } \\
\text { (re)conhecível, logo no assentamento das } \\
\text { informações sobre um conjunto de } \\
\text { pressupostos já presente no universo do } \\
\text { leitor e que o levam a assumir o caráter } \\
\text { evidente do real da imprensa, ou seja, há um } \\
\text { forte trabalho no interdiscurso de modo a } \\
\text { manter os consensos de significação. }\end{array}$ \\
\hline
\end{tabular}

O quadro mostra que jornalismo e publicidade, embora tenham propósitos aparentemente muito distintos, operam em vários espaços de intersecção. Em última instância, ambos visam, ainda que por percursos diferentes, à busca do lucro para suas empresas. E, por mais que a publicidade tenha como alvo um determinado grupo consumidor e o jornalismo se disponha a falar para um público mais amplificado, normalmente os segmentos sociais para os quais ambos se direcionam são coincidentes. Trata-se de discursos que procuram agregar seres humanos em busca de uma identidade, de uma personalidade que os vinculem à sociedade de alguma maneira (CASAQUI, 2000, p 174). Também buscam, cada um a seu modo, manter a imagem de uma marca, seja pelos valores positivos incutidos em um determinado produto pela publicidade, seja pela aura da crebilidade que um veículo midiático 
constrói continuamente diante da sociedade. Segundo Casaqui (ibid., p. 64), em consonância com a teoria de Bakhtin, "a atribuição de valor que é dada a um objeto pelo discurso publicitário só existe a partir do ponto em que este valor é reconhecido socialmente, por um determinado segmento que compartilha certos comportamentos e visões de mundo”. Isso vale tanto para a publicidade quanto para o valor das notícias de um determinado veículo.

Casaqui (ibid., p. 54) lembra também que tanto jornalismo quanto publicidade apresentam um caráter cíclico, diretamente vinculado a um aspecto sazonal (ambos devem tratar periodicamente de assuntos como a chegada do verão, o Dia dos Pais, a Páscoa, a Copa do Mundo etc). Outro fato agregador é que seus discursos são autoreferenciais, uma vez que remetem a seu próprio passado para municiar sua atividade no presente. Os manuais de redação e estilo divulgados pelos grandes veículos recomendam ao jornalista que faça uma pesquisa no arquivo para que não se repitam abordagens anteriores ou ideias que parecem novas e não são. Assim como, para a publicidade, os Anuários do Clube de Criação de São Paulo são uma fonte de consulta indispensável para quem está começando na profissão.

Diante dessas características comuns, era natural que, ao longo do tempo, jornalismo e publicidade viessem a desenvolver formas de expressão em que um se aproveitasse de certas características do outro, numa espécie de simbiose em que os próprios fundamentos das duas linguagens se confundem, como tentaremos demonstrar por meio dos exemplos de anúncios publicitários e chamadas de capas dos diários gratuitos modernos. As próprias transformações dentro do campo jornalístico foram levando a essa aproximação. Antes do advento da internet e do surgimento em profusão de portais de notícias, o segmento dos jornais impressos tinha uma preocupação muito reduzida em inovar na forma como apresentar uma notícia, tanto textualmente como graficamente.

Até o início dos anos 90, os “jornalões” - e o uso do termo neste contexto carrega um tom pejorativo pela associação com um modo conservador de produzir e vender informação tinham uma resistência em trazer elementos novos às suas páginas. A diagramação se resumia a fotos e textos, em geral extensos. Infográficos apareciam muito ocasionalmente. A oferta de informação trazida pela internet não só aumentou muito como possibilitou ao consumidor midiático acessar vários outros canais, como vídeo, som, gráficos animados etc. Informar deixou de ser apenas relatar um determinado fato com precisão e suposta imparcialidade; passou a ser algo que dialoga muito perto com o entretenimento (uma discussão mais detalhada sobre esse tema será feita na próxima seção desta pesquisa). Com um pouco de demora, os jornais perceberam que não poderiam mais manter os mesmos modos de produção. Era preciso tentar atrair um público recém-ingresso na sociedade da informação por 
meio da internet, que já não se interessava em buscar notícias em um meio impresso. Para tal feita, valia tanto produzir notícias de forma mais leve, com termos menos "sisudos", como repaginar o projeto gráfico. Quase todos os grandes jornais brasileiros passaram, em maior ou menor intensidade, por esse processo de readaptação, e foi justamente no discurso publicitário em que boa parte deles se amparou para realizar essas reformas.

(...) o jornalismo, percebendo essa necessidade de diferenciação e, sobretudo, de adequação aos ditames histórico-sociais, buscou na publicidade uma forma mais leve, imersa no humor e na liberdade discursiva para a construção das notícias. A mensagem publicitária, que sempre teve como estratégias discursivas peculiares a sedução, a persuasão e o entretenimento, cede à imprensa estas estratégias e permite a produção de um discurso jornalístico que, além de informar, agora também entretém, é sedutor e é persuasivo. (CARRERA, 2007, p. 02)

Essa proximidade não causou mudanças apenas no discurso jornalístico, mas também influenciou o discurso publicitário. Dentro de uma lógica em que um veículo impresso dá mais espaço a novas linguagens e o público não vê isso como uma desvirtuação da imagem da marca, os anúncios publicitários ganham um vasto terreno de experimentação, como num teste dos limites entre cada linguagem. Tornam-se mais comuns peças publicitárias que reproduzem o discurso jornalístico para tentar associar seu produto a um valor de verdade, ou aquelas que apenas "brincam” com os gêneros de discurso do jornalismo para chamar a atenção de seu público. Casaqui retoma, aí, o conceito bakhtiniano de plurilinguismo, isto é, o imbricamento de diversas linguagens que leva a combinações inusitadas e um aparente conflito de estilos por causa do cruzamento de gêneros distintos. Falamos, aqui, do

(...) estranhamento causado pela presença do recorte do jornal, da fotografia de imprensa, inseridos em uma composição de anúncio publicitário estranhamento a serviço da criação intencional de interesse na comunicação persuasiva, para chamar a atenção do público-alvo a que se destina (CASAQUI, 2000, p. 69)

Mas o próprio Casaqui (ibid., pp. 27-28) afirma que, no atual contexto dos mercados publicitário e jornalístico, esse “estranhamento” tem sido cada vez mais atenuado. O que importa é a adequação entre os gêneros absorvidos pela publicidade e o repertório do públicoalvo a que se destina à mensagem. Por exemplo, se um anúncio de uma marca de carro reproduz, fac-símile, uma notícia que destaca o fato de essa marca ter sido apontada como a mais segura de sua categoria, o leitor pode até achar inusitado o fato de uma reportagem ser inserida em um contexto publicitário, mas provavelmente esse dado lhe causará uma reação 
positiva e a imagem desse carro, para ele, ganha novos atributos. A partir do momento em que passou a influenciar outros campos da comunicação, notadamente o jornalístico, a publicidade deixou de ser apenas um discurso restrito a seu espaço historicamente adquirido e ganhou uma nova configuração.

Chegamos a um momento histórico em que a publicidade caracteriza-se mais por ser um princípio organizador de outros gêneros assimilados, adotados com base na adequação ao universo de valores, à memória discursiva e aos pressupostos próprios do público-alvo que se pretende sensibilizar ao ato de consumo" (CASAQUI, 2005, p. 30)

Grillo (2003) diz que a publicidade, em sua tentativa de ocultar sua finalidade comercial, se vale de uma argumentação indireta, que ganha forma por meio do uso de diversos gêneros discursivos. E lança mão da descrição de Adam e Bonhomme (1997) da publicidade como um metagênero, "capaz de absorver a pluralidade dos gêneros discursivos existentes, dissimulando-se atrás dessas categorias discursivas.

\footnotetext{
Essa estratégia visa a suavizar a agressividade constitutiva da propaganda, enquanto instrumento comercial, ao preço de apagar-se enquanto gênero distinto. Já a imprensa possui gêneros estáveis (podendo, inclusive, serem utilizados pela propaganda com objetivos persuasivos) que se constituem por sua transparência em relação à realidade, através da mobilização de recursos icônicos, como a fotografia, e linguísticos, como o discurso relatado, os títulos e a descrição. (GRILLO, 2003, p. 53)
}

Convém, ainda, atentar para o fato de que a proximidade entre jornalismo e publicidade não se dá apenas no campo teórico, mas também, e de forma muito mais explícita, no suporte midiático. A convivência secular de anúncios ao lado de notícias, no mesmo plano de expressão, certamente facilita esse diálogo, "pois tanto um como outro discurso são suscetíveis de serem apreendidos pelo mesmo leitor, no mesmo ato de leitura (BARBOSA; CASAQUI, 2000, p. 78).” Quando dois discursos chegam a esse nível de dialogia, "não existe um distinto do outro, mas os dois fundidos. Há assimilação do públicoalvo a essa nova expressão (materialidade) discursiva/histórica, o que, de nossa parte, é decorrente de um contrato de comunicação fiduciário 'publijornalístico'. (COAN, 2010, p. 259)”. Comungamos da ideia de um discurso tão imbricado que já se pode descrevê-lo como publijornalístico, tal como definimos em nosso objeto de pesquisa.

Uma vez que temos como foco o estudo da relação entre publicidade e jornalismo nos diários gratuitos modernos, é fundamental entender como esses veículos se enxergam e de que maneira eles esperam que o público os assimile, ou seja, qual é o ethos do Metro e do Destak. 
Defendemos a tese de que a hibridização entre discurso jornalístico e publicitário alcançou um novo patamar com a chegada dos gratuitos ao Brasil, dadas as condições de produção desses veículos e sua identificação profunda com os valores de uma sociedade de consumo. É sobre o que vamos discorrer nas próximas páginas.

\subsection{O ETHOS DOS GRATUITOS MODERNOS NA SOCIEDADE DE CONSUMO}

O que um leitor espera ao acessar a página principal do site de um jornal? Muito provavelmente, notícias hierarquizadas com um resumo do assunto, reproduzindo no campo virtual a capa da versão impressa. Ao entrar no site do diário Metro (http://www.publimetro.band.com.br), um internauta mais desavisado pode achar que se enganou. A homepage do Metro nem de longe se parece com a dos veículos tradicionais. Primordialmente, porque não traz uma lista de notícias, com manchete e submanchetes, como se pode constatar na reprodução abaixo.

Figura 3.2.1 - Reprodução do site brasileiro do diário Metro
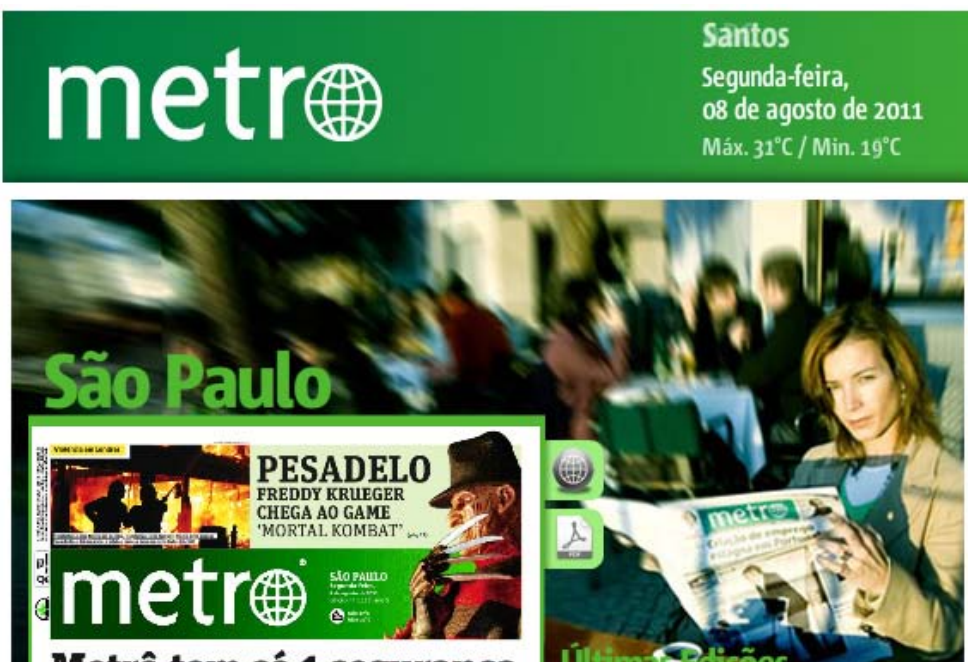

Metrô tem só 1 segurança para cada 3 mil usuários

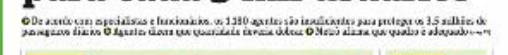
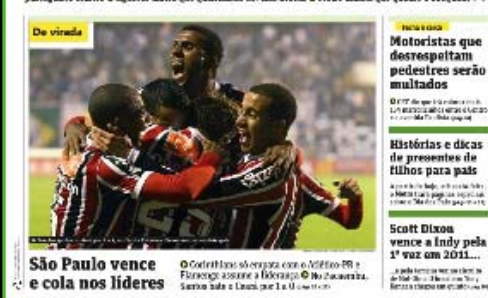

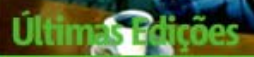

São Paulo

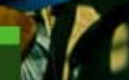

Rio de Janeiro

Curitiba

Campinas

$A B C$

Santos

Metro Quadrado

Metro Motor

Para ler a versāo PDF você precisa ter instalado em seu computador o plugin Adobe "m Acrobat PDF. Clique aqui e faça o download do plugin.

3 S Siga-nos no Twitter e Facebook

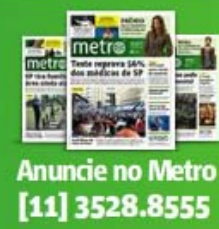

Säo Paulo

Midia Kit Tabela de Preços ilo de Janeiro

Midia Kit Tabela de Preços Curitiba

Midia Kit Tabela de Preços Campinas

Midia Kit Tabela de Preços ABC

Midia Kit Tabela de Preços

Santos

Midia Kit Tabela de Preços

Macional

Midia Kit Tabela de Preços

Metro Quadrado (sprang)

Midia Kit Tabela de Preços

Metro Motor (spenaig)

Midia Kit Tabela de Preços

49. Assista o video de algumas

* açoes diferendadas do Metio

0 maior jornal

do Mundo.

23 países

84 edições

150 cidades

Conheças as outras ediçōes 
A reprodução da capa da edição do dia, cujo conteúdo só pode ser acessado clicando na opção de visualização em arquivo PDF, é a única referência ao conteúdo noticioso do jornal. Todo o canto direito da página, ocupando um espaço destacado, tem como alvo os anunciantes. Para cada cidade onde o Metro está presente no Brasil, há um link para o chamado "mídia kit”, ou seja, um conjunto de informações sobre o perfil dos leitores do gratuito (cujos detalhes serão expostos adiante) e as possibilidades de disposição dos anúncios nas páginas do veículo. Ao lado, a tabela de preços para cada tipo de peça publicitária. Na parte de baixo, uma mensagem informando que o Metro é “o maior jornal do mundo”, uma vez que possui edições em 150 cidades de 23 países.

Para não deixar nenhuma margem de dúvida de que a página é feita mais para o público-anunciante do que para o público-leitor, há um link para um vídeo com algumas “ações diferenciadas” do Metro. Não se trata de nenhuma cobertura jornalística especial ou de uma campanha social do diário, mas sim de um jargão para designar formas chamativas de anunciar um produto enquanto os exemplares são distribuídos nas ruas.

No vídeo, há imagens de uma ação para divulgar o novo sabor canela do líquido de higiene bucal Cepacol. Os “promotores” do Metro - é assim que o jornal chama os funcionários responsáveis pela distribuição - aparecem fantasiados com uma máscara de uma boca gigante com dentes brancos à mostra, como se estivessem representando o personagem que é o garoto-propaganda da marca. Mais adiante, há imagens de uma ação de publicidade do NudeDay, da marca de lingeries Hope. Aproveitando o apelo do Dia Internacional da Mulher, em 8 de março, a marca promove, em algum sábado desse mês, uma campanha em que a cliente compra uma calcinha e leva outra grátis. E, a cada peça vendida, a Hope se compromete a doar R\$ 1 para o Grupo de Apoio ao Adolescente e à Criança com Câncer (GRAACC). No ano passado, a equipe de distribuição do Metro foi acompanhada por modelos que vestiam apenas uma camisa branca promovendo o NudeDay e uma calcinha Hope (como na imagem da página seguinte). O vídeo mostra ainda que várias pessoas paravam para tirar fotos com as modelos, que acabaram virando atração no trânsito. A trilha sonora do vídeo é a música Let’s Get It Started, da banda pop americana Black Eyed Peas, que é uma das mais tocadas em casas noturnas de São Paulo no momento. Um dia depois de as modelos desfilarem de calcinha e um exemplar do Metro à mão, o diário publicou na edição de 12 de março de 2010, à página 6, uma pequena nota com o chapéu "Ação na Paulista” e o título “Campanha une Metro e Hope”, acompanhada de uma foto das jovens que 
era muito semelhante à reprodução da cena do vídeo que separamos para a pesquisa. O texto da nota era o seguinte:

A marca de lingerie Hope e o jornal Metro inovaram e colocaram ontem 16 modelos espalhadas pela Avenida Paulista e no cruzamento das avenidas Rebouças com Estados Unidos e Juscelino Kubitschek, em São Paulo, vestidas apenas com calcinhas Nude e camisetas. A ação promoveu a campanha NudeDay, que acontece amanhã, nas lojas Hope. ${ }^{9}$

Figura 3.2.2 - Modelos em campanha do Metro de divulgação do NudeDay

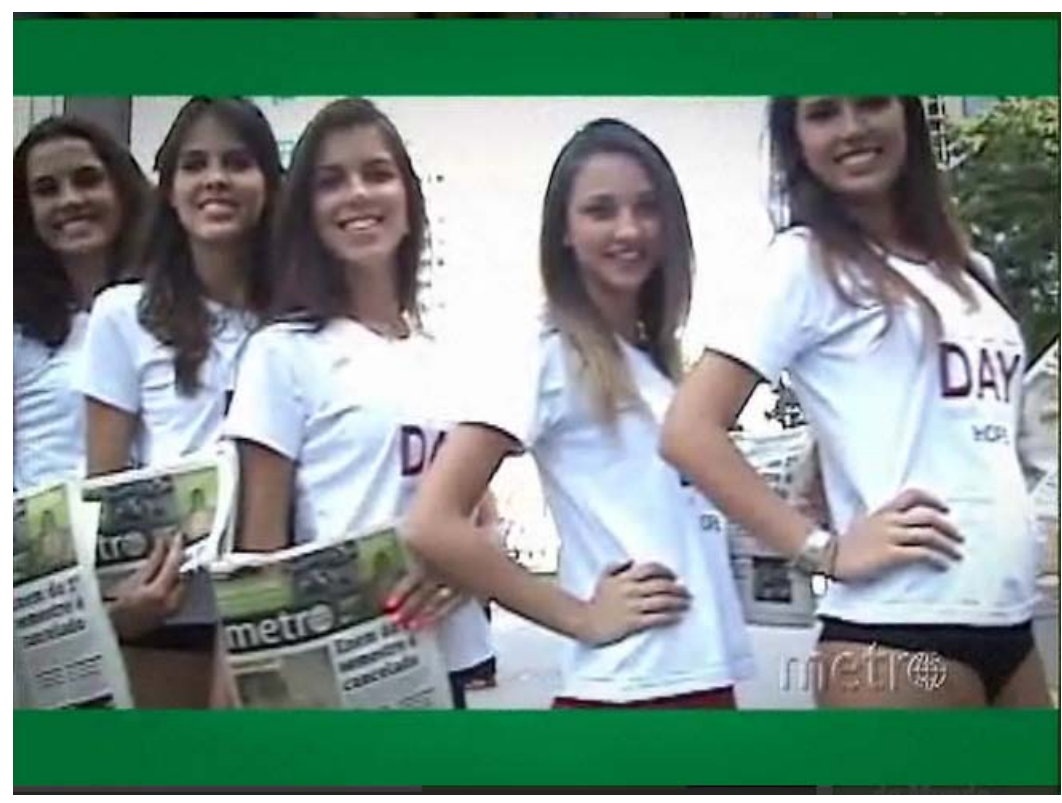

O que mais chama a atenção nesta nota é o fato de ela ocupar, dentro da edição, um espaço de conteúdo noticioso - não há nenhum anúncio na página -, e fazer referência evidente a uma campanha publicitária. Não há nenhuma restrição a associar o nome do diário a uma marca comercial. A parceria é reportada de forma natural, e o passeio das modelos pela cidade é tratado como uma notícia de fato, utilizando-se de procedimentos típicos do discurso jornalístico, como o formato do lead respondendo às perguntas básicas do “quem?”, “o quê?”, “quando?” e “onde?”. A estruturação é jornalística, mas apenas com o intuito de dissimular uma intencionalidade publicitária.

Os exemplos do site e das “ações diferenciadas” do Metro - o Destak também poderia ser tomado como exemplo, porque igualmente promove esse tipo de iniciativa, ainda que não tão de forma explícita em sua homepage - foram aqui expostos para demonstrar como a identidade dos diários gratuitos modernos se diferencia sobremaneira dos jornais pagos convencionais ou mesmo de outros meios de comunicação tradicionais. Basta pensar se um

\footnotetext{
${ }^{9}$ Metro São Paulo, 12/03/2010, p. 6
} 
veículo como O Estado de S. Paulo ou a TV Globo se permitiriam ter esse tipo de vinculação quase simbiótica de suas marcas com um determinado anunciante.

Em 2006, quando o Destak foi lançado em São Paulo e se tornou o primeiro gratuito moderno no Brasil, muito pouco se sabia sobre as características desse tipo de publicação. A referência que a maioria dos paulistanos - principalmente aqueles com idade acima de 30 anos - tinha sobre um jornal diário gratuito era a do Metrô News, fundado em 14 de setembro de 1974 por Paschoal Thomeu, ex-prefeito de Guarulhos e ex-deputado estadual, falecido em 2006. O primeiro exemplar saiu no mesmo dia em que a linha 1-Azul do Metrô de São Paulo era inaugurada. Não se tratava de uma coincidência. O próprio nome do periódico sugeria a relação com o meio de transporte, e o jornal nasceu justamente para ser distribuído nas estações paulistanas. Thomeu teve essa ideia de associar um produto jornalístico aos usuários do transporte público 21 anos antes de o grupo $\mathrm{AB}$ Kinnevik bancar a proposta de três jornalistas suecos e lançar o Metro. Sob essa ótica, é inegável seu papel inovador dentro do mercado midiático brasileiro.

O que se pretende mostrar, porém, é que os gratuitos modernos não foram assim chamados à toa por Piet Bakker para diferenciá-los de gratuitos anteriores. Metro e Destak estabeleceram aqui uma nova lógica de relação com a linguagem publicitária que absolutamente se desconhecia. A diagramação mais sofisticada e a mescla entre noticiário local e internacional, este essencialmente voltado ao mundo do show business e do entretenimento em geral, possibilitaram aos novos gratuitos cultivar uma imagem de jornal “jovem”. Na comparação com eles, o antigo Metrô News envelheceu ainda mais. Manteve um design com poucas alterações em relação às origens dos anos 70, e tampouco inovou no tipo de cobertura jornalística, muito restrita a assuntos da capital e do ABC paulista e a temas mais enfadonhos, como divulgação de políticas públicas e de serviços à população. Só recentemente o Metrô News ganhou uma roupagem mais moderna, com a criação de cadernos segmentados de turismo, diversão, saúde, imóveis e automóveis. Aparentemente, uma medida tomada de forma reativa, sob influência de Metro e Destak, que desde o início deram espaço a seções customizadas para atrair um determinado mercado anunciante.

O caso do Metrô News é bastante ilustrativo para discutir o ethos dos gratuitos modernos - isso dentro do conceito proposto pela corrente francesa da $\mathrm{AD}$, segundo a qual o enunciador deve tentar construir uma imagem de si que seja condizente com seu objetivo de argumentação e que também leve em consideração aquilo que o coenunciador espera dele por uma impressão pré-estabelecida, seja de maneira estereotipada ou não. Explica-se: em entrevista concedida a este autor em abril de 2009, a jornalista Noelly Russo, então editora- 
geral do Metro Brasil, se queixou do fato de que, mesmo dois anos depois do lançamento do Metro no país, pesquisas com leitores mostravam que muitos deles ainda o confundiam com o Metrô News. Assim que chegou ao Brasil, o jornal se chamava PubliMetro, mas a empresa achou o nome pouco atraente e houve a mudança para Metro. O motivo de preocupação de Noelly era com o fato de o público vincular a marca do seu gratuito com o Metrô News - um jornal que, para ela, “tem uma imagem mais popular e com um perfil de público que não é o nosso". Eis aí um aspecto essencial para entender o ethos de ambos os gratuitos modernos brasileiros. A gratuidade e a distribuição nas ruas podem fazer crer que esses jornais são dirigidos a um público muito diversificado, de todas as classes sociais. Não é o que acontece. Tanto Metro quanto Destak são muito claros em relação a quem pretendem alcançar. Em seu site, o Destak diz que seu público-alvo “é formado principalmente por jovens, economicamente ativos e essencialmente urbanos”10. Também em abril de 2009, o diretor editorial do Destak no Brasil, Fábio Santos, afirmou em entrevista a este autor: "Nós atendemos a uma demanda do mercado publicitário para as classes A, B e C.” Já Noelly Russo disse que “o foco do Metro é a classe A, de 20 a 30 anos”. Ela esclareceu que, ao se referir à classe $\mathrm{A}$, não está fazendo menção a uma exígua fatia dos muito ricos, mas sim à faixa social assim estabelecida de acordo com os critérios do Instituto Brasileiro de Geografia e Estatística (IBGE), que considera pertencentes à classe A aqueles que possuem renda domiciliar mensal acima de 20 salários mínimos - nesse grupo entram tanto os milionários como jovens profissionais liberais bem-sucedidos. Os dois jornais fazem pesquisas de mercado frequentes para saber qual é o perfil de seu leitor e se está de acordo com o que busca o veículo. Vamos, primeiro, apresentar números divulgados pelo Metro.

Gráfico 3.2.1 - Divisão de leitores do Metro por faixa etária

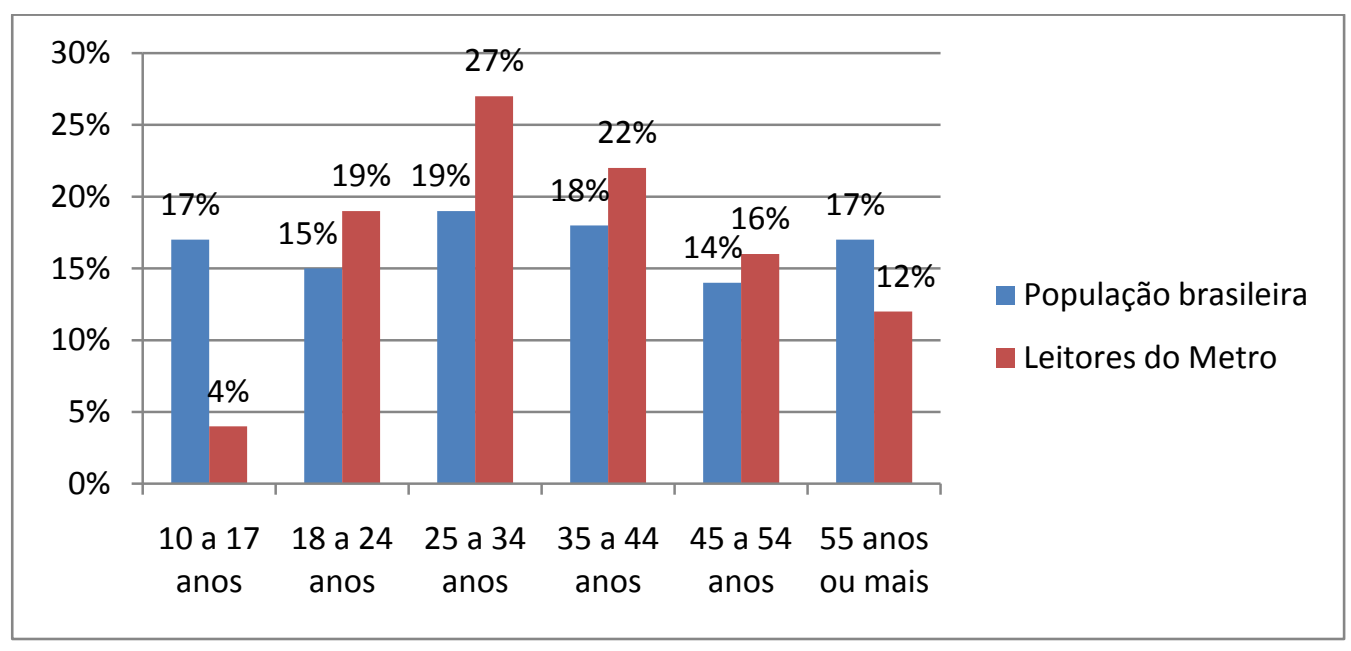

\footnotetext{
${ }^{10}$ Trecho disponível em http://www.destakjornal.com.br/institucional.aspx
} 
Gráfico 3.2.2 - Divisão de leitores do Metro por classificação sócio-econômica

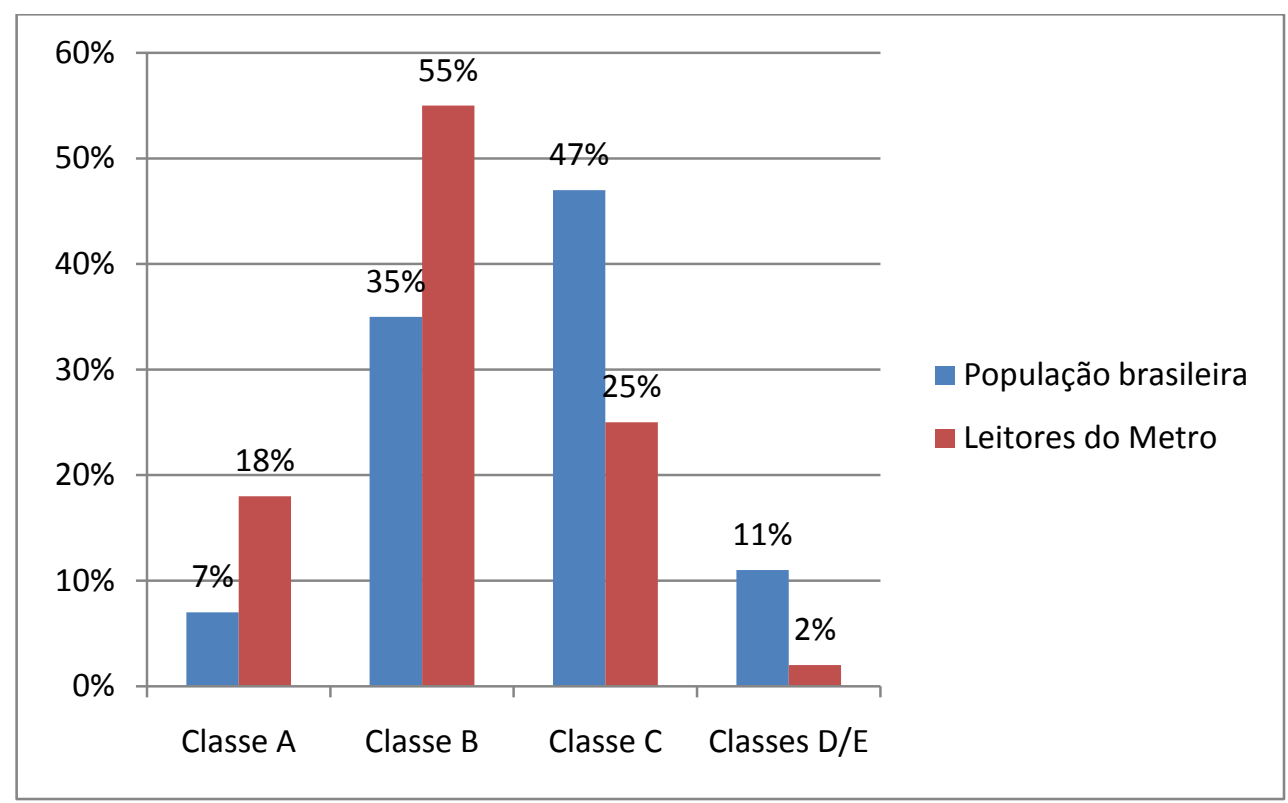

Gráfico 3.2.3 - Divisão de leitores do Metro por sexo

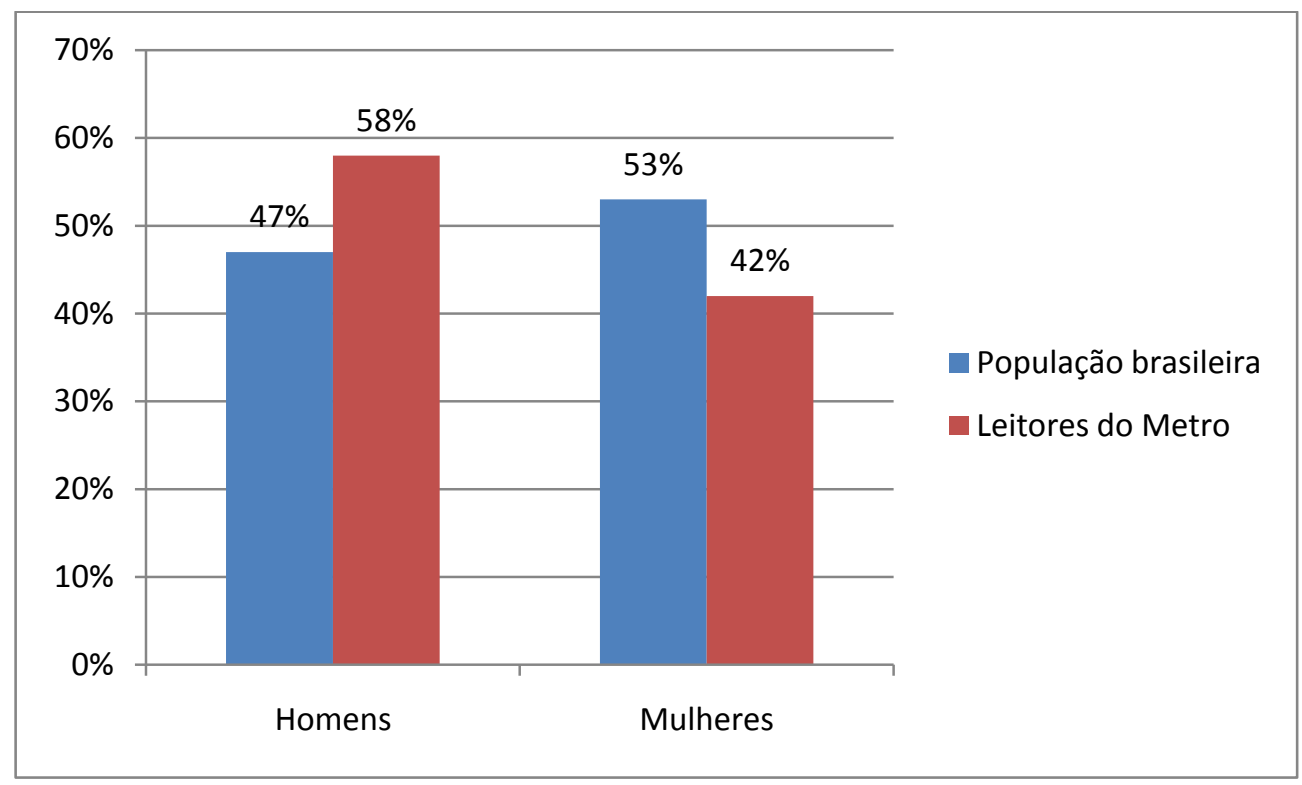

Fonte: Ipsos - Estudos Marplan/EGM - Janeiro a dezembro de 2009 - Grande São Paulo

Diante dos números, constata-se que quase 70\% dos leitores do Metro possuem entre 18 e 44 anos e que 73\% deles pertencem às classes A e B - estes dois indicadores, aliás, aparecem com destaque na tabela de preços para anunciantes, disponível no site. É um sinal manifesto de que o fato de se dirigir a um público jovem e com boa situação financeira é tratado como prioritário para o jornal no que diz respeito à atração de publicidade.

Agora, os números do Destak. Como a pesquisa a que tivemos acesso foi feita um ano antes da que apresentamos acima sobre o Metro, não há base comparativa possível entre os 
dois gratuitos. O levantamento feito para o Destak também não inclui os dados sobre a população brasileira, tal como observado na pesquisa anterior. Portanto, temos apenas as informações referentes ao Destak, sem uma análise em perspectiva com outro indicador.

Gráfico 3.2.4 - Divisão de leitores do Destak por faixa etária

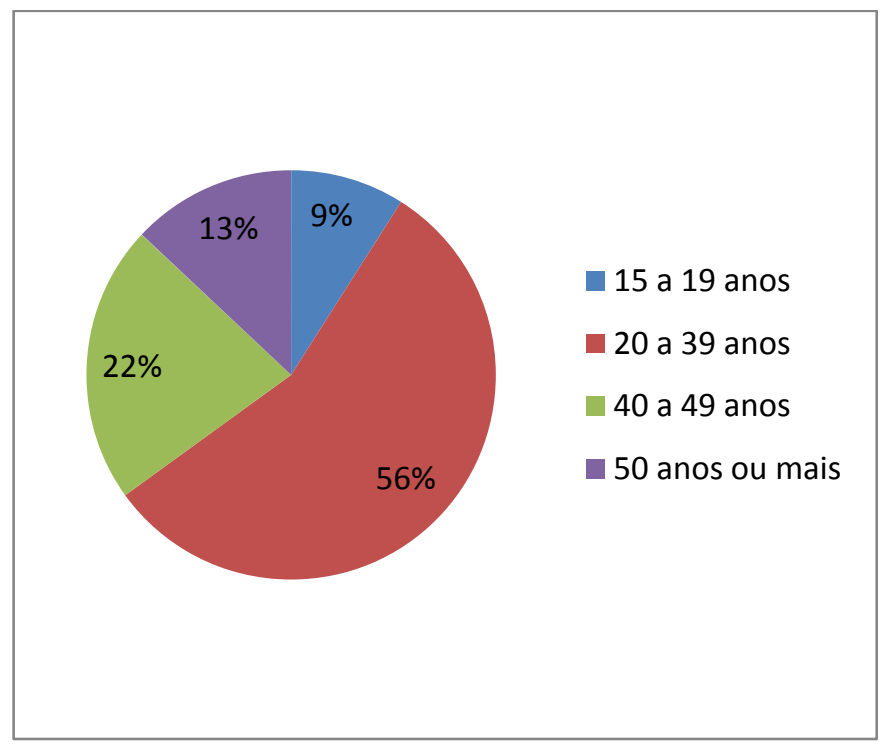

Gráfico 3.2.5 - Divisão de leitores do Destak por classificação sócio-econômica

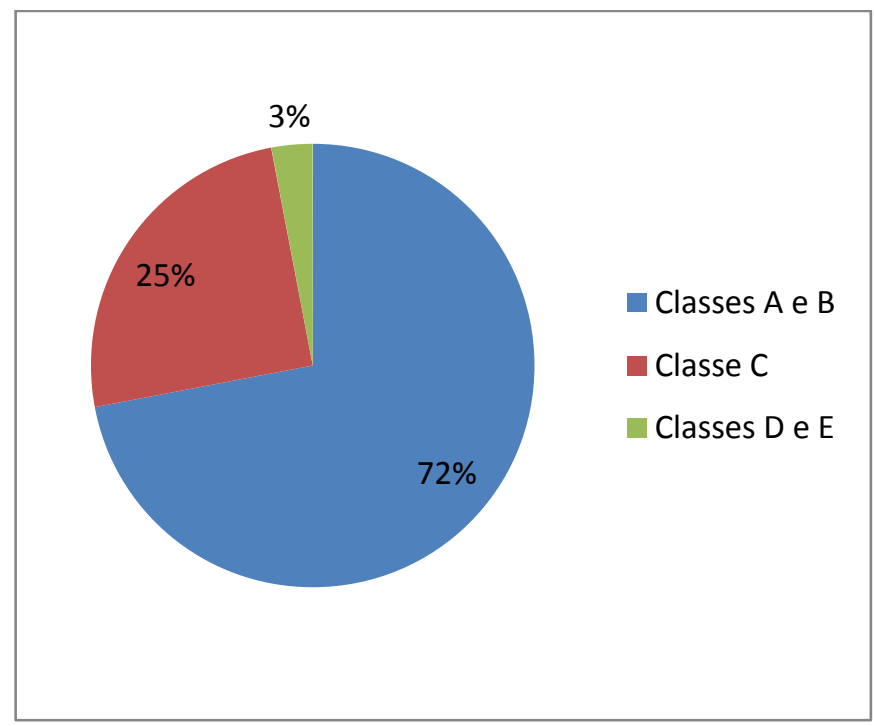


Gráfico 3.2.6 - Divisão de leitores do Destak por sexo

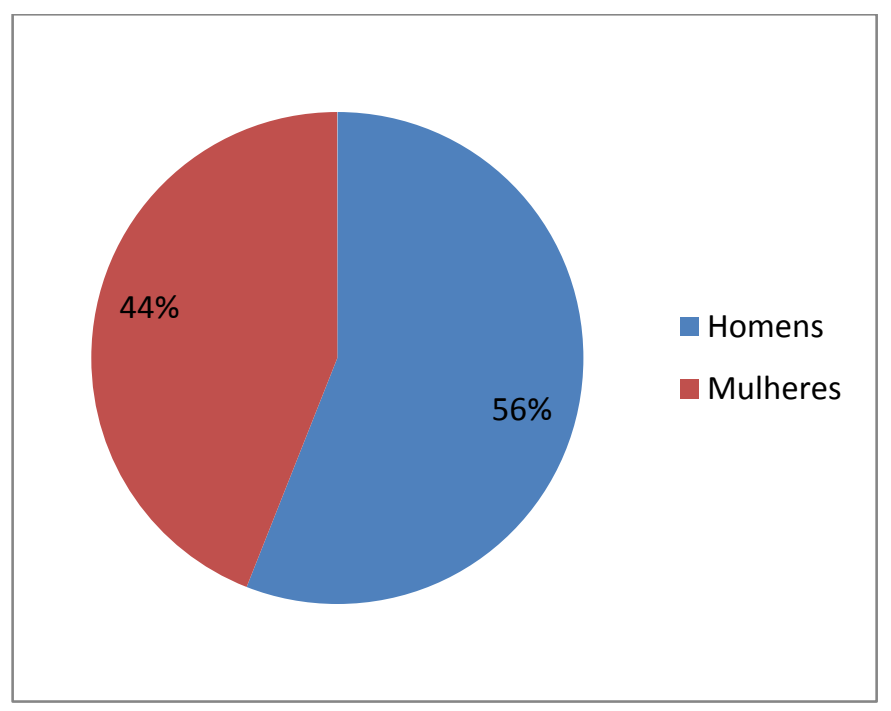

Fonte: Ipsos Marplan - Janeiro a dezembro de 2008 - São Paulo

Assim como seu principal concorrente, o Destak também concentra seus leitores em uma faixa jovem (78\% possuem entre 20 e 49 anos) e de bom poder aquisitivo (72\% fazem parte das classes A e B). A pesquisa do Destak traz ainda outros dados interessantes para entender quem é buscado pelos gratuitos. Do total dos leitores do jornal,

- 85\% possuem telefone celular

- 82\% estão ativos no mercado de trabalho

- 77\% acessam a internet

- 74\% pretendem viajar (dentro do Brasil, nos próximos 12 meses)

- 66\% têm automóvel em casa

- 62\% têm entre nível médio e superior completo

- 51\% possuem cartão de crédito

Esses dados não são destacados pela pesquisa por acaso. São, em sua maioria, vinculados a hábitos de consumo, para demonstrar que o leitor do Destak é um potencial alvo de interesse de diferentes tipos de anunciantes, como operadoras de telefonia celular, agências de viagens, concessionárias e administradoras de cartões. No fim do levantamento, há um quadro com uma mensagem que deixa claro por que essas informações foram destacadas: “...Pessoas urbanas, ritmos de vida acelerados e extremamente difíceis de utilizar as mídias tradicionais. Público altamente procurado e desejado pela maioria dos anunciantes...”

Se a distribuição dos gratuitos é feita de mão em mão nas ruas, em tese qualquer pessoa poderia pegar um exemplar. Mas esses veículos conseguem fazer com que sejam 
bastante reduzidas as chances de uma "qualquer" pessoa, não muito bem-vinda para o público-alvo visado de seus anunciantes, receber um Metro ou Destak enquanto caminha. A estratégia está na forma e nos pontos da cidade onde há distribuição. A prioridade está em distribuir para motoristas e deixar clara essa predisposição aos anunciantes, pois “o mercado publicitário não usa transporte coletivo”, nas palavras de Fábio Santos, do Destak. Pedestres só costumam receber um exemplar se eles se dispuserem a pedi-lo a um distribuidor. O Metro, contrariando a própria origem da matriz sueca, não realiza distribuição nas estações de metrô. Não por acaso, os gratuitos de São Paulo não circulam aos fins de semana, feriados e no período festivo entre o Natal e o Ano-Novo - em todas essas situações, o fluxo de automóveis na capital paulista cai bastante. O mapa dos pontos de distribuição reflete claramente o objetivo de buscar o público mais qualificado possível. Ambos os gratuitos concentram-se nos cruzamentos mais nobres de São Paulo, restringindo sua presença à região centro-sul da capital - as zonas leste e norte, mais pobres, têm pouquíssimos pontos, geralmente localizados em “bolsões” de riqueza em determinados bairros. Mazon (2010, p. 39) traz um mapa de São Paulo com os 350 pontos fixos e os 135 pontos de tráfego (cruzamentos) do sistema de distribuição do Metro. É fácil notar que a maioria deles está concentrada nas regiões de Pinheiros, Consolação, Itaim-Bibi, Jardim Paulista e Moema, todas elas áreas abastadas da cidade.

Figura 3.2.3 - Mapa dos pontos de distribuição do Metro em São Paulo

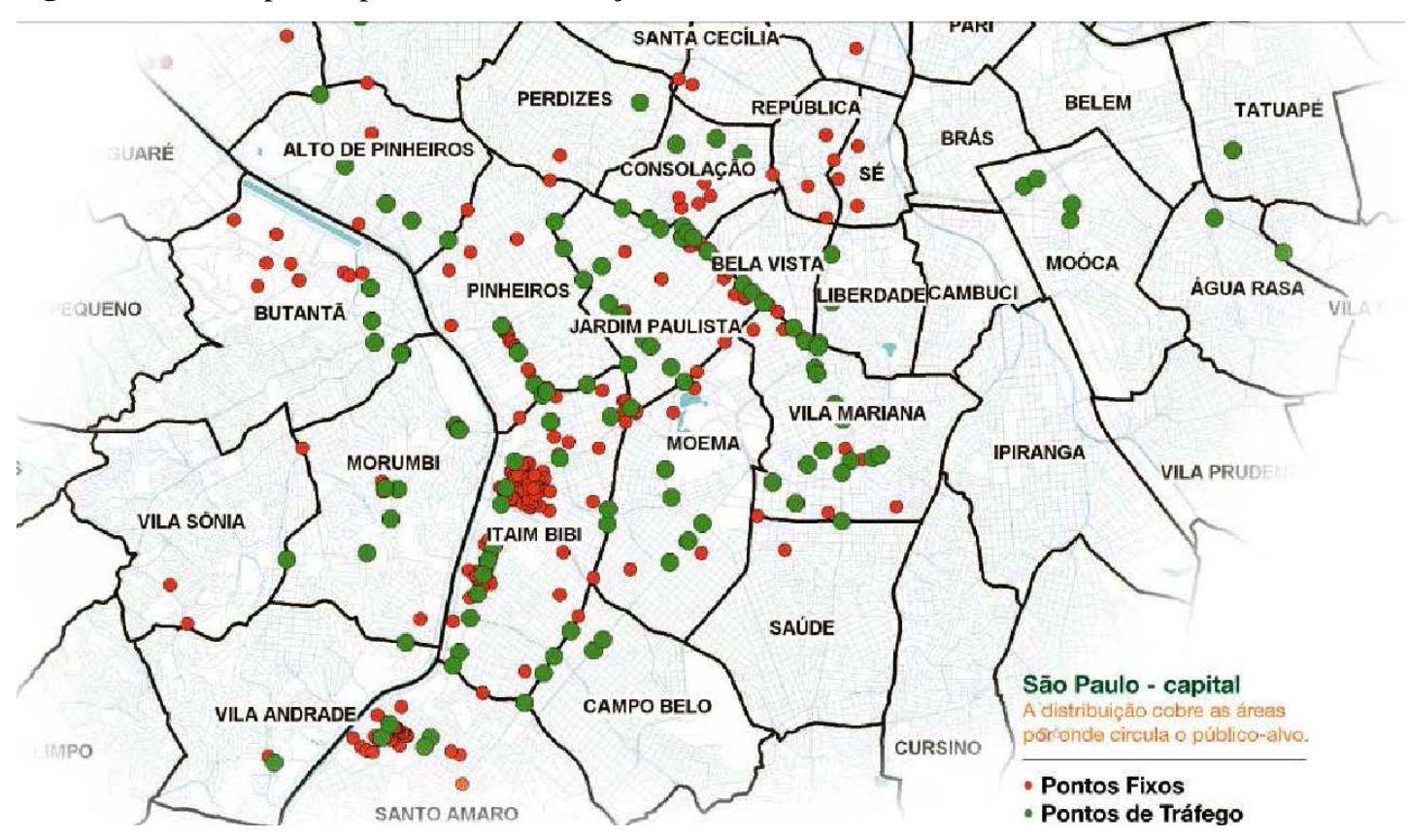


Embora não disponhamos de um mapa com detalhamento semelhante da distribuição do Destak, podemos afirmar que funciona praticamente da mesma maneira, com estratégias muito parecidas. Em seu site, o jornal diz quais são as regiões onde é possível encontrá-lo. São elas:

- Berrini/Brooklyn

- Granja Julieta/Chácara Santo Antônio

- Ibirapuera

- Klabin/Ipiranga/Cursino

- Moema

- Morumbi/Campo Limpo

- Vila Mariana/Paraíso

- Alto de Pinheiros/Lapa/Vila Leopoldina

- Pompeia/Perdizes

- USP/Butantã

- Jardins/Pinheiros/Vila Olímpia/Itaim-Bibi

- Paulista/Cerqueira César

- Mooca/Anália Franco/Tatuapé

- Casa Verde/Santana/Vila Guilherme

Nota-se que há muitas áreas semelhantes ao raio de atuação do Metro. A única diferença é que o Destak aposta mais em alguns bairros um pouco mais afastados dos pólos de negócios da capital onde há uma presença de classes sócias ascendentes, como os bairros do Tatuapé, na zona leste, e da Vila Guilherme, na zona norte. Mas longe de se poder dizer que a distribuição atinge camadas populares.

Retomando a discussão sobre a identidade do público-alvo dos gratuitos, Noelly Russo diz que o Metro International, que reúne todas as edições do Metro globalmente, tem como objetivo se aproximar dos urbanites - na definição dela, “os jovens que gostam de diversão e entretenimento em geral”. Este termo em inglês pode se referir tanto a quem vive na cidade como a alguém que gosta do estilo de vida urbano e compartilha de seus valores. Na visão do Metro, os urbanites são jovens “descolados” que não se interessam pela mídia convencional e são mais receptivos às diversas propostas do discurso publicitário porque foram criados em um ambiente de intenso entrecruzamento de ideias. Pois, diz Canclini (1999, p. 285), "sem dúvida, a expansão urbana é uma das causas que intensificaram a hibridação cultural.” As 
grandes cidades são, por excelência, o espaço mais propício para trocas, sejam elas culturais, mercadológicas ou de hábitos de consumo. No contexto da América Latina, Canclini diz que

Passamos de sociedades dispersas em milhares de comunidades rurais com culturas tradicionais, locais e homogêneas, em algumas regiões com fortes raízes indígenas, com pouca comunicação com o resto de cada nação, a uma trama majoritariamente urbana, em que se dispõe de uma oferta simbólica heterogênea, renovada por uma constante interação do local com redes nacionais e transnacionais de comunicação. (id, ibid, p. 285)

O urbanite, personificação do público visado pelos gratuitos modernos, é um consumidor por natureza. Isso porque está inserido totalmente no que se conveio chamar de sociedade de consumo, uma espécie de entidade invisível que dita a seus integrantes o que é preciso ou não ambicionar, independentemente de essa ambição ser fundamentada em um processo de escolhas circunscritas ao campo da racionalidade, da ponderação entre argumentos favoráveis ou contrários.

\begin{abstract}
"Sem dúvida a sociedade de consumo pressupõe a mercantilização das relações sociais e um mínimo de poder aquisitivo, mas como sistema de valores e organização institucional trata-se de um sistema cultural e ideológico que permeia o conjunto da sociedade, em grande parte de forma independente da estratificação social e da renda individual. O mundo do consumo homogeneíza a vida material e o gosto, no sentido de que transforma todos os produtos em mercadorias produzidas em massa e divulgadas através da publicidade, ao mesmo tempo que busca adaptar-se à diversidade cultural e social de mercados. A sociedade de consumo é fundamentalmente igualitária, no sentido de que tende a criar uma estética universal em sua vontade de transformar todas as pessoas em consumidores" (SORJ, 2000, pp. 48-49)
\end{abstract}

Vivemos, portanto, na era da modernidade-mundo, assim definida por Trindade.

A modernidade-mundo é hoje o resultado do processo histórico percorrido
pelo sistema capitalista, que passou pela modernidade fundamentada na razão
Iluminista, quando se originou a sociedade burguesa, pautada na organização
política do Estado nacional e que, pela contínua necessidade de expansão
econômica desse mesmo sistema, concretiza, na contemporaneidade, uma
sociedade de consumo mundial, na qual o Estado-nação perde sua força,
impondo novas formas de perceber a relação social entre os indivíduos e de
suas dinâmicas no espaço e no tempo (TRINDADE, 2005, p. 84)

Se nós vivemos hoje uma sociedade de consumo, boa parte desse fenômeno se deve a um processo de fetichização do objeto de desejo, seja ele qual for. É o que Haug (1997) chama de estética da mercadoria, que rege os princípios da relação entre produção e consumo. São eles, em suma, a valorização de tudo o que é novo; do moderno, ou seja, 
daquilo que é prático, funcional; da capacidade de seduzir advinda dos objetos de consumo e da predominância do valor de troca.

Eis, acima, uma verdadeira síntese do ethos dos gratuitos Metro, Destak e os congêneres que operam ao redor do mundo. Todos eles mantêm uma busca incessante por símbolos de inovação e modernidade. Há um receio constante de não se deixar parecer obsoleto ou mesmo estar vinculado ao antigo, e o exemplo da confusão das marcas Metro e Metrô News diz muito sobre isso.

Pode-se argumentar que o jornalismo, como discurso em si, sempre visa a trazer informações novas ao seu leitor; cabe explicar, porém, que falamos de instâncias diferentes. Um diário convencional, por regra, preocupa-se em mostrar algum aspecto ainda desconhecido de um determinado assunto, mas nem por isso vai deixar de buscar em algum conceito pregresso ou no relato de uma história antiga um argumento para construir o sentido pretendido em uma notícia. Nos gratuitos modernos, via de regra, são evitadas digressões no fluxo comunicacional ou referências históricas que não se prendem única e exclusivamente à “célula” da notícia, que são os já mencionados atributos do lead. A razão é simples: o espaço exíguo para as reportagens - em geral cerca de um terço do tamanho das notícias nos jornais pagos - é um fator impeditivo para uma elaboração discursiva mais complexa. Tudo tem de ser o mais funcional possível para o público-alvo, constituído de cidadãos com "ritmos de vida acelerados”, retomando o trecho da frase que acompanhava a pesquisa de perfil dos leitores do Destak. Nenhum dos gratuitos espera que seu leitor demore mais de 30 minutos para ler uma edição inteira; afinal, neste intervalo ele já pode ter chegado ao escritório e dificilmente vai preferir se debruçar sobre uma folha de jornal em detrimento da facilidade de um clique de mouse para acessar qualquer tipo de informação à qual queira ter acesso. Ao ser perguntada sobre o que era o Metro para ela, Noelly Russo nos ofereceu uma definição muito apropriada e sintomática do espaço-tempo que testemunhamos. “O Metro é uma internet de papel com a chancela do impresso.” E, bem-humorada, explicou a expectativa do jornal para com seu público-alvo ao lhe oferecer esse produto noticioso: "Com o Metro, você pelo menos não vai passar vexame com os amigos”, sugerindo que a leitura do diário permite uma mínima apreensão do mundo ao redor - e nada muito além disso, diga-se.

Se o Metro é “uma internet de papel”, é preciso descobrir como ele opera para atrair os outrora apenas internautas da comunicação. Diz Arroyo: 
unas condiciones de gratuidad y proximidad (adquisición sin pasar por el quiosco) y un formato de lectura rápida, que constituye una excepción en la prensa diaria y un acicate para el consumo. Además, la prensa gratuita ofrece contenidos muy accesibles, de carácter generalista, donde prima el entretenimiento. Unos contenidos con profusión de noticias triviales y anecdóticas, cuya única pretensión es hacer pasar un buen rato al lector con historias curiosas, amenas y divertidas. Una fórmula que apuesta por la oferta de servicios, una de las prioridades en la agenda de los gratuitos, en la que puede encontrarse una guia muy completa de espectáculos y posibilidades para llenar el tiempo de ocio o el fin de semana. Todo ello hace de la prensa gratuita un medio muy atractivo para los jóvenes, que requiere, sobre todo, poco esfuerzo: un factor importante para la "generación@”. (ARROYO, 2008, p. 2) ${ }^{11}$

Desta maneira, o percurso de geração de sentido trilhado pelos gratuitos para alcançar e cativar os urbanites passa pela adaptação da notícia como produto sob a lógica de múltiplas concorrências mercadológicas. E, para tanto, a notícia deve se render ao que estabelece o imperativo da moda, da estética (LIPOVETSKY, 1989). Desta feita, não pode prescindir da capacidade de seduzir aqueles jovens que "gostam de diversão e entretenimento em geral”, nas palavras de Noelly Russo.

Assim, a linguagem do mercado espalha-se pelo mundo acompanhando o mercado. Torna-se presente em muitos lugares, invade quase todos os círculos de relações sociais. O mesmo processo de mercantilização universal universaliza determinado modo de falar, taquigrafar, codificar, pensar. (...) O mesmo processo de globalização do capitalismo mundializa signos e símbolos, logotipos, slogans, qualificativos e estigmas (IANNI, 2000, p. 219)

A referência à globalização é, sem dúvida, pertinente para as circunstâncias sob as quais está inserido o modo de vida social na maioria das comunidades urbanas. Mas as características dos gratuitos modernos - com cada edição funcionando como um representante local de uma empresa midiática transnacional/global, condição esta muito evidente no caso do Metro - nos obriga a recorrer a um outro conceito, o de glocalização, cuja noção está intimamente vinculada ao micromarketing (ROBERTSON, 2000), a saber, a personalização e comercialização de produtos e serviços de base global ou quase global em uma escala local.

\footnotetext{
${ }^{11}$ Tradução do autor: "Quais são os pontos-chave de um produto que conseguiu interessar à geração@, um público-alvo que tem demonstrado preferir os jornais digitais aos de papel? Os jovens podem ter encontrado na imprensa gratuita condições de gratuidade e proximidade (aquisição sem passar pela banca de jornais) e um formato de leitura rápida que constituem uma exceção na imprensa diária e um incentivo para o consumo. Além disso, a imprensa gratuita oferece conteúdos muito acessíveis, de caráter generalista, em que prima o entretenimento. São conteúdos com profusão de notícias triviais e anedóticas, cuja única pretensão é fazer com que o leitor se distraia com histórias curiosas, amenas e divertidas. Uma fórmula que aposta na oferta de serviços, uma das prioridades na agenda dos gratuitos, onde se pode encontrar um guia muito completo de espetáculos e possibilidades para preencher o tempo do ócio ou do fim de semana. Tudo isso faz da imprensa gratuita um meio muito atrativo para os jovens, pois requer, sobretudo, pouco esforço: um fator importante para a geração@”
} 
Quase não é preciso dizer que no mundo da produção capitalista para mercados cada vez mais globais, a adaptação às necessidades locais e condições específicas não é apenas um caso de resposta comercial à existente variedade global - como também civilizacional, regional, societária, étnica, de gênero e ainda outros tipos de consumidores diferenciados - como se variedade ou heterogeneidade existisse por si mesmo. Em grau considerável o micromarketing - ou, em expressão mais abrangente, a glocalização envolve a construção de consumidores cada vez mais diferenciados, a "invenção" das "tradições do consumidor" (das quais o turismo, demonstradamente a maior "indústria do mundo contemporâneo, é, sem dúvida, o exemplo mais claro) (id., ibid, p. 251)

Tal como uma multinacional de qualquer setor da economia, uma empresa midiática com operações em diversos países tem de se preocupar em, ao mesmo tempo, manter uma imagem universal de sua marca (o logo do Metro e do Destak é o mesmo em qualquer lugar do mundo) e desenvolver projetos que possam ter um vínculo com o local sem perder de vista o global. O Metro International traz um bom exemplo de glocalização com suas chamadas iniciativas globais. Elas funcionam como uma "tradição inventada”, usando os conceitos de Robertson: em determinados dias do ano, várias edições do Metro são produzidas com foco em um tema específico. Há, por exemplo, a edição Metro Verde, sobre meio ambiente, em 22 de abril, e a Metro Rosa, em ocasião do combate mundial contra o câncer de mama, em outubro. Segundo Noelly Russo, esses números especiais agradam ao público-alvo pela sensação de pertencimento a causas globais, por imaginar que o tema sobre o qual se está lendo na edição de São Paulo é o mesmo que uma pessoa vai ler em Paris, Hong Kong ou Santiago, para citar algumas metrópoles onde o jornal está presente. Qualquer filial do Metro pode sugerir a criação de uma edição global, e em 2007 o Brasil convenceu a matriz a lançar o Metro Água.

Um aspecto interessante é que não há obrigatoriedade de adesão das filiais a todas as edições temáticas. O Brasil, por exemplo, optou por não fazer parte do Metro Happy, uma edição que circula em janeiro e cujo objetivo é trazer apenas notícias positivas. A decisão foi tomada por uma razão muito prática: “Não há espaço para isso em um noticiário cheio de tragédias como o nosso”, afirma Noelly Russo. Não é exagero por parte da editora. Em 2009, a Metro Happy foi publicada na mesma semana em que houve o desabamento do teto do templo da igreja evangélica Renascer em Cristo, em São Paulo, com oito mortos e dezenas de feridos. A proximidade dos fatos certamente traria constrangimentos à edição brasileira. A recusa do Metro Brasil à edição Happy é um exemplo bastante ilustrativo de glocalização, pois estamos falando de uma estratégia de inserção de um valor global em várias localidades, mas deixando espaço para que se considerem as peculiaridades de cada realidade - no caso 
brasileiro, as freqüentes notícias negativas em decorrência da criminalidade, das tragédias naturais, da corrupção política e de outros males com interferência humana ou não.

É compreensível entender por que as iniciativas globais causam boa impressão no público-alvo pela ideia de comungação de valores socialmente responsáveis, mas não se pode deixar de lado a constatação de que a pretensa preocupação com as grandes questões mundiais também é uma maneira de marketing institucional. Basta ver quanto dinheiro empresas de setores que tradicionalmente causam algum tipo de efeito colateral às comunidades investem em projetos de "responsabilidade social” para melhorar sua imagem. Essas mesmas empresas sempre estarão à procura de canais para divulgarem ao público seu compromisso com esses valores. E a maneira mais eficiente e aceita nos grandes centros urbanos para fazer isso é por meio do discurso publicitário. Não por acaso, edições especiais como a Metro Verde normalmente trazem vários anúncios de companhias em que são elencadas todas as suas ações na busca por um “mundo melhor”. Trata-se de um negócio em que todos ganham, em que papel da publicidade como discurso intermediador é absolutamente fundamental. Afinal, como afirmam Barbosa e Trindade,

\begin{abstract}
A publicidade, parte mais visível e brilhante do composto promocional de que o marketing é constituído, significa, no contexto da cultura contemporânea, uma das atividades de maior prestígio. De outro lado, seu discurso pode ser considerado exemplar e matricial: quer do ponto de vista da promoção de bens e serviços que ajudam a sustentar a circulação das mercadorias materiais e não-materiais da sociedade chamada Pós-moderna; quer por usar estratégias e discursos que persuadem, seduzem e encantam; quer como sustentáculo simbólico-ideológico da cultura globalizada que, em maior ou menor grau, nos envolve a todos (BARBOSA; TRINDADE, 2001, p. 114)
\end{abstract}

Dentro da lógica do conceito de ethos, os gratuitos modernos buscam se associar a símbolos globais, especialmente da área de entretenimento, para fazer com que seu discurso esteja em sintonia com as expectativas de mundo de seu público-alvo, ou seja, em constante dialogia entre enunciador e coenunciador. Um exemplo de que essas publicações estão circunscritas no jogo publicidade-entretenimento (uma questão que será abordada mais detidamente um pouco mais adiante, com a análise das chamadas de capa) foi a iniciativa de o Metro convidar a estrela pop global Lady Gaga a ser “editora convidada” para todas as edições do diário no mundo. O especial foi publicado globalmente em 17 de maio de 2011. Abaixo, algumas capas pelo mundo (da esquerda para a direita, as edições de São Paulo, da Cidade da Guatemala, de Paris e de Nova York). 
Figura 3.2.4 - Capas do Metro com Lady Gaga

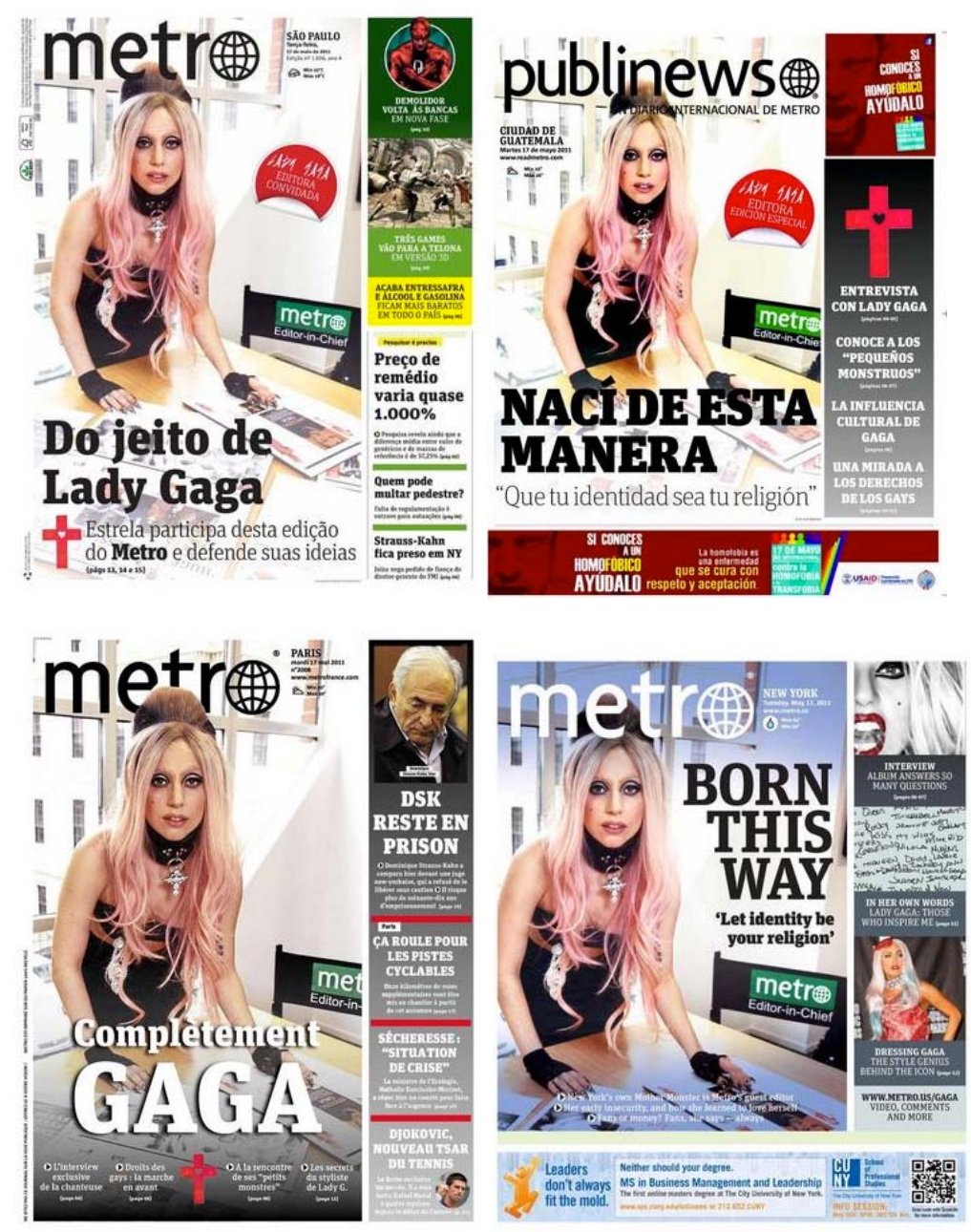

Uma observação mais atenta dessas quatro edições, postas lado a lado, nos fornece outros elementos interessantes para a discussão sobre glocalização. Dentro do contexto de uma sociedade urbana ávida pelo consumo de símbolos de mercado, especialmente os de entretenimento se nos referimos ao recorte dos urbanites, Lady Gaga é um ícone valioso. Portanto, fica claro pelas capas que se tratava de uma obrigação de todas as filiais dar manchete e foto principal para sua participação na edição do Metro. Assim, não importava se naquela mesma ocasião houvesse um fato verdadeiramente autêntico - isto é, não uma realidade construída, como a ida de Gaga à sede do Metro para viver um dia de editora - e de relevância para determinado local. Essa situação de conflito fica evidente na capa do Metro de Paris. Ela não é reservada exclusivamente à cantora, como é o caso das edições de Nova York e da Cidade da Guatemala (onde o jornal não é chamado de Metro, mas sim de Publinews). No canto superior direito, a primeira chamada diz que "DSK reste en prison” ("DSK permanece na prisão”, em francês). O DSK em questão é uma abreviação das iniciais do 
francês Dominique Strauss-Kahn, o então diretor-gerente do Fundo Monetário Internacional (FMI). Três dias antes da capa de Gaga, DSK foi detido no aeroporto John F. Kennedy, em Nova York, prestes a embarcar para Paris. A acusação da polícia era a de que ele teria abusado sexualmente de uma camareira em um hotel de luxo. Strauss-Kahn ficaria na cadeia porque o juiz para o qual ele depôs lhe havia negado o pedido de fiança.

Pela importância do personagem, o assunto ganhou repercussão mundial e passou a ocupar a manchete de todos os jornais. Aparentemente, também seria a do Metro de Paris, mas a “intromissão” da “editora” Lady Gaga impediu que isso acontecesse. O que mais chama a atenção nesse caso, porém, é que o Metro de Nova York, justamente a cidade para onde os olhos do mundo estavam voltados para acompanhar o caso DSK, simplesmente ignorou o grande fato jornalístico daquele momento, debaixo de seu nariz. Reservou toda a capa para Gaga, com exceção feita a um anúncio publicitário no rodapé. Diante do dilema entre cumprir as determinações da matriz, evidentemente de tom publicitário, e registrar na capa a notícia mais importante naquela ocasião, os editores franceses optaram por uma solução mista, abarcando o "local” (DSK estava em Nova York, mas é francês e surgia como principal candidato de oposição ao presidente Nicolas Sarkozy) sem deixar de destacar Lady Gaga. Já na balança da edição nova-iorquina, a publicidade/entretenimento/global ficou com tudo, e o jornalismo/local com nada.

Sobre a edição de São Paulo, nota-se que adotou a mesma estratégia de capa da parisiense. A parte central foi dedicada a Lady Gaga e o canto direito trouxe tanto submanchetes locais ("Preço de remédio varia quase 1000\%" e "Quem pode multar pedestre?”) como uma internacional, justamente sobre a manutenção da prisão de DSK. Folheando a edição paulistana, é possível entender qual foi a exata dimensão do trabalho da “editora” Lady Gaga. Dentro do jornal, excetuando-se evidentemente a capa, apenas três páginas se referiam ao pacote com a cantora - na verdade, duas e meia, pois em uma delas havia um anúncio de meia página. E só na última o leitor entende por que ela foi convidada. Comemora-se, em 17 de maio, o Dia Internacional contra a Homofobia e a Transfobia. Uma vez que Lady Gaga tem um grande apelo entre o público gay, nada mais apropriado ao Metro do que atrair a atenção desse segmento da sociedade por meio da associação de sua imagem com a de um símbolo de luta pelos direitos dos homossexuais. Sob o suposto argumento de dar destaque a esse dia internacional, o diário soube unir jornalismo, publicidade e entretenimento. Uma ação com o DNA de um gratuito moderno.

No entanto, diante da coincidência de o caso Strauss-Kahn ter tido um importante desdobramento naquela mesma data, é oportuno se fazer a seguinte pergunta: o que teria 
acontecido se as edições do Metro, baseadas exclusivamente pelo critério de relevância jornalística, decidissem dar manchete para a história do ex-diretor-gerente do FMI? E se destinassem um espaço muito menor à ação institucional do jornal de convidar Lady Gaga para fazer as vezes de “editora”? Os leitores ficariam chocados com essa atitude? A maioria, provavelmente, não. Porque faz parte do contrato jornalístico o papel do leitor de esperar do produtor da notícia que tome decisões ponderadas sobre como hierarquizá-las.

Diante dessa discussão, nos parece oportuno recorrer às discussões sobre o grau de exposição do campo jornalístico, tais como são expostas por Bourdieu (1997).

\begin{abstract}
(...) assim como o campo político e o campo econômico, e muito mais que o campo científico, artístico ou literário ou mesmo jurídico, o campo jornalístico está permanentemente sujeito à prova dos vereditos do mercado, através da sanção, direta, da clientela ou, indireta, do índice de audiência (ainda que a ajuda do Estado possa assegurar certa independência com relação às pressões imediatas do mercado). $\mathrm{E}$ os jornalistas são sem dúvida tanto mais propensos a adotar o "critério do índice de audiência" na produção ("fazer simples", "fazer curto" etc.) ou na avaliação dos produtos e mesmo dos produtores ("passa bem na televisão", "vende bem” etc.) quanto ocupem uma posição mais elevada (diretores de emissora, redatores-chefes etc.) em um órgão mais diretamente dependente do mercado (uma emissora de televisão comercial por oposição a uma emissora cultural etc.), sendo os jornalistas mais jovens e menos estabelecidos mais propensos, ao contrário, a opor os princípios e os valores da "profissão" às exigências, mais realistas ou mais cínicas, de seus "veteranos”. (BOURDIEU, 1997, p. 106)
\end{abstract}

Convém ressalvar, como se percebe claramente, que Bourdieu se refere às especificidades do modo de produção televisivo. Entretanto, a ideia central de sua argumentação é aplicável a qualquer tipo de suporte midiático, uma vez que os conflitos, em sua natureza primordial, são muito semelhantes. Na sociedade de consumo em que estamos inseridos, as diretrizes do mercado sempre terão um peso significativo nas decisões do fazer jornalístico, mesmo sendo aquelas em que só há atores internos, como repórter e editor. E isso não ocorre somente em situações até razoavelmente comuns dentro de um jornal, como publicar ou não uma notícia que pode prejudicar a imagem de um grande anunciante do veículo. Isso ganha uma proporção ainda maior dentro da realidade de um diário gratuito, em que os anúncios publicitários representam o único meio de sustentação financeira. No caso dos gratuitos, intensifica-se o conflito entre as tradicionais técnicas jornalísticas de hierarquização e dimensionamento de uma notícia e a assimilação de uma nova valoração do que é visto como relevante para o público-alvo. É impossível afirmar com segurança como reagiriam os leitores urbanites do Metro de uma determinada cidade quando se deparassem com Strauss-Kahn na manchete e apenas uma chamada menor para uma participação especial 
de Lady Gaga nessa mesma edição. Mas pode-se dizer que haveria um certo estranhamento desse leitor, porque talvez gostasse de ver seu ídolo com o destaque que ele julga merecido. Seu julgamento ainda poderia ser influenciado se, pela internet, ele comparasse a edição de sua cidade com uma eventual capa do Metro de outro lugar em que Lady Gaga aparecesse de página inteira. De qualquer forma, os gratuitos modernos, em nossa opinião, estão ainda mais sujeitos que um jornal convencional às regras (implícitas ou explícitas) impostas pelo mercado. Seja o mercado-leitor quanto o mercado-anunciante, duas entidades que, como vimos, se interpenetram de tal forma no mundo atual que é difícil delimitar o espaço de cada um, ainda mais na construção de sentido de um diário gratuito.

\subsection{REAÇÃO DA MÍDIA TRADICIONAL À CHEGADA DOS GRATUITOS}

O autor desta pesquisa trabalhava na redação do jornal O Estado de S. Paulo quando, no início de 2006, começaram a ser ouvidos rumores de que um novo jornal, com um projeto “diferente”, seria lançado em São Paulo. Colegas passaram a receber propostas para participar do tal projeto, mantido sob extremo sigilo dentro do meio jornalístico. O mercado ficou sabendo apenas poucas semanas antes do primeiro número, de 6 de julho de 2006, que estava desembarcando no Brasil o Destak, um jornal gratuito cuja sede era Portugal. Havia muito pouca informação a respeito desse tipo de veículo impresso e não se tinha ideia de como os gratuitos se acomodariam na realidade jornalística brasileira. Os estudos de mercado disponíveis vinham - e ainda vêm - basicamente da Europa, onde nasceram os gratuitos modernos. Bakker (2002) pesquisou vários exemplos da maneira como esses jornais se integraram ao mercado editorial de cada país e chegou a cinco modelos básicos de ingresso.

Tabela 3.3.1 - Modelos de ingresso de mercado dos jornais gratuitos modernos

\begin{tabular}{|c|c|c|}
\hline Tipo de modelo & Características & Exemplos pelo mundo \\
\hline Invasão & $\begin{array}{l}\text { Utilizado basicamente por grandes } \\
\text { empresas internacionais, é } \\
\text { caracterizado pela contenção } \\
\text { máxima de custos, com uma } \\
\text { equipe de redação mínima e boa } \\
\text { parte do conteúdo oriunda de } \\
\text { agências de notícias. O lucro é a } \\
\text { única razão para manter o negócio }\end{array}$ & $\begin{array}{c}\text { O Metro e o conglomerado } \\
\text { norueguês Schibsted, dono do } \\
\text { maior gratuito espanhol, o } 20 \\
\text { Minutos, já fecharam edições em } \\
\text { Buenos Aires, Colônia e Zurique. } \\
\text { No Brasil, consideramos que tanto } \\
\text { o Metro como o Destak se valeram } \\
\text { dessa estratégia }\end{array}$ \\
\hline Defesa & $\begin{array}{l}\text { Grupos que publicam jornais pagos } \\
\text { no mesmo mercado em que } \\
\text { possuem gratuitos. Trata-se do } \\
\text { lançamento de um gratuito como } \\
\text { reação ao surgimento anterior de } \\
\text { outro. A empresa não investiria se } \\
\text { não tivesse sido "incomodada" }\end{array}$ & $\begin{array}{c}\text { O maior jornal pago holandês, o } \\
\text { De Telegraaf, lançou o seu gratuito } \\
\text { Sp!ts exatamente no mesmo dia em } \\
\text { que o Metro lançou sua edição em } \\
\text { Amsterdam. Não há nenhum } \\
\text { exemplo conhecido no Brasil }\end{array}$ \\
\hline
\end{tabular}




\begin{tabular}{|c|c|c|}
\hline Expansão & $\begin{array}{l}\text { Guarda certa semelhança com o } \\
\text { modelo de defesa. Nesse caso, um } \\
\text { grupo de mídia local lança o } \\
\text { gratuito para obter uma sinergia } \\
\text { com o título pago na busca por } \\
\text { anunciantes, na distribuição e, } \\
\text { em alguns casos, até mesmo no } \\
\text { compartilhamento } \\
\text { de conteúdo noticioso }\end{array}$ & $\begin{array}{l}\text { O Metro da Bélgica (sem relação } \\
\text { com o Metro International). Não } \\
\text { existem casos desse tipo no Brasil }\end{array}$ \\
\hline Prevenção & $\begin{array}{c}\text { Ocorre quando uma empresa } \\
\text { jornalística lança um veículo } \\
\text { gratuito antes de todos com o } \\
\text { objetivo de desestimular uma } \\
\text { possível concorrência }\end{array}$ & $\begin{array}{c}\text { Vários exemplos no Reino Unido, } \\
\text { Áustria, Noruega, França etc. Não } \\
\text { há casos semelhantes no Brasil }\end{array}$ \\
\hline Promoção & $\begin{array}{c}\text { Caracteriza-se pelo lançamento de } \\
\text { um diário gratuito para funcionar } \\
\text { como um chamariz para uma } \\
\text { publicação tradicional }\end{array}$ & $\begin{array}{l}\text { Daily News Express, extinto } \\
\text { gratuito pertencente ao grupo do } \\
\text { tabloide New York Daily News. No } \\
\text { Brasil, o Jornal Placar, do Grupo } \\
\text { Abril, circulou por alguns períodos } \\
\text { como forma de atrair o interesse } \\
\text { para a publicação de fundo, a } \\
\text { tradicional revista Placar. Também } \\
\text { houve o exemplo do MTV na Rua, } \\
\text { gratuito do canal jovem MTV, } \\
\text { também da Abril }\end{array}$ \\
\hline
\end{tabular}

Como afirmamos no quadro anterior, Destak e Metro chegaram a São Paulo adotando um modelo semelhante ao da invasão. Originários de grupos de comunicação estrangeiros, trouxeram a estratégia de baixo custo, equipe enxuta e aproveitamento intensivo de conteúdo de agências de notícias para a confecção de suas notas. O lançamento do Destak foi divulgado pela mídia convencional, inicialmente, como uma questão de negócios, de mais um investimento no Brasil, sem nenhum questionamento de ser um possível concorrente. Como relatou esta reportagem de O Estado de S. Paulo.

O grupo português Cofisa e o empresário brasileiro Andre Jordan investirão 3,5 milhões de euros (pouco menos de R\$ 1 milhão) no lançamento do Destak, jornal em formato tablóide que será distribuído gratuitamente na cidade de São Paulo a partir da próxima quinta. Do total, 30\% do capital é do grupo Cofisa e $70 \%$ de Jordan.

"O modelo do jornal gratuito cresce muito no exterior. Após pesquisarmos, vimos que o Brasil, e especialmente São Paulo, poderia ser outro local de sucesso para esse tipo de publicação", diz o diretor comercial do Destak, Cláudio Zorzett. A tiragem inicial será de 200 mil exemplares por dia, distribuídos em universidades, shopping centers, centros empresariais, hospitais e nos cruzamentos de avenidas como Faria Lima, Paulista, Brasil e Europa. (...). ${ }^{12}$

O mercado jornalístico brasileiro ainda estava assimilando a ideia de jornais gratuitos e, evidentemente, reagiu às práticas desses novos veículos. Antes de detalharmos como se

\footnotetext{
12 “Jornal gratuito começa a circular em São Paulo”. O Estado de S. Paulo, 29/06/2006
} 
desenrolou esse processo, é interessante apresentar um quadro sobre os tipos de reação da imprensa escrita tradicional, formulado por Picard (2001), outro estudioso dos gratuitos.

Tabela 3.3.2 - Modelos de reação da imprensa tradicional

\begin{tabular}{|c|c|}
\hline \multicolumn{2}{|c|}{ Mercado com diários gratuitos } \\
\hline $\begin{array}{l}\text { Protecionismo } \\
\text { - o grupo tradicional compete com o gratuito, } \\
\text { cria um título próprio e oferece novidades } \\
\text { aos leitores para não perder market share }\end{array}$ & $\begin{array}{l}\text { Extensão } \\
\text { - os diários tradicionais buscam } \\
\text { diversificar seus anunciantes, tentando } \\
\text { se apropriar de parte do crescimento do } \\
\text { bolo publicitário advindo dos gratuitos }\end{array}$ \\
\hline Negação de benefícios aos gratuitos & Busca de benefícios com os gratuitos \\
\hline $\begin{array}{l}\text { Obstrução } \\
\text { - negação total de espaço aos gratuitos } \\
\text { por meio de ações na Justiça ou recusa à } \\
\text { entrada deles em associações de classe }\end{array}$ & $\begin{array}{l}\text { Coexistência } \\
\text { - os jornais pagos decidem não competir } \\
\text { com os gratuitos e preferem demonstrar } \\
\text { as diferenças de linhas editoriais }\end{array}$ \\
\hline \multicolumn{2}{|c|}{ Mercado sem diários gratuitos } \\
\hline
\end{tabular}

Seguindo os conceitos desse quadro, podemos dizer que, passados os primeiros meses de observação, os jornais pagos brasileiros, especificamente os da cidade de São Paulo, passaram a adotar uma clara estratégia de obstrução ante os gratuitos. Aliás, algo que não chega a ser surpreendente, pois o tipo de reação mais comum da mídia convencional ao redor do mundo tem sido mesmo a de lutar contra a imprensa gratuita no início. Na França, esse conflito ganhou dimensões preocupantes. O Metro chegou a Paris no fim de 2001, com uma tiragem de aproximadamente 200 mil exemplares. Os sindicatos ligados à imprensa tradicional fizeram mais de 400 piquetes na capital e conseguiram destruir 50 mil exemplares. A violência foi tanta que o segundo número foi impresso em Luxemburgo para evitar quebradeira. Lá, o argumento da Federação Nacional da Imprensa Francesa foi alertar para o risco à credibilidade jornalística advindo de uma informação “indissociável de uma iniciativa 
puramente publicitária” (EDO, 2004). Aqui no Brasil, a primeira manifestação contrária veio no início de 2007, por parte da Associação Nacional de Jornais (ANJ), que pediu ao Ministério Público do Estado de São Paulo uma investigação sobre uma suposta irregularidade na administração do Destak. O órgão que reúne os grandes jornais pagos levantou a hipótese de que o gratuito seria dirigido por estrangeiros - algo proibido pela Constituição Federal, cujo artigo 222 estabelece que brasileiros natos ou naturalizados há mais de dez anos devem ter o controle de ao menos 70\% das ações uma empresa jornalística, além do comando administrativo. No caso do Destak, 70\% das ações são do empresário português naturalizado brasileiro Andre Jordan, e o restante está nas mãos de dois grupos portugueses. A ANJ teria alertado para o fato de que seis dos sete membros do conselho de administração do jornal naquela época eram portugueses, ligados aos sócios minoritários. O Destak, então, disse ao MP que Jordan se naturalizara havia 50 anos e que a gestão da empresa cabia a dois brasileiros natos.

A investigação parou por aí, mas o cerco aos gratuitos persistiu e se intensificou com a vinda do Metro, em abril de 2007. Mesmo sem admitir publicamente, os jornais pagos passaram a questionar a Prefeitura de São Paulo sobre a possibilidade de os gratuitos estarem desrespeitando a Lei Cidade Limpa ao distribuírem suas edições nas ruas. Tal lei, aprovada em setembro de 2006 e conhecida por ter banido os outdoors da capital, trazia várias normas sobre a regulamentação da paisagem urbana, mas não era aplicável ao caso dos gratuitos. A pressão para se adotar alguma medida que dificultasse a circulação de Metro e Destak foi aumentando até que, em outubro de 2007, o prefeito Gilberto Kassab (DEM) sancionou uma lei que proibia a distribuição gratuita de panfletos, folhetos e jornais nas ruas de São Paulo. O veto era total nas esquinas com semáforos, não por acaso os principais pontos em que os gratuitos são distribuídos. Nos demais lugares, os jornais precisariam ter um mínimo de 80\% de "matérias jornalísticas” para poderem ser distribuídos - um patamar aparentemente feito para inviabilizar os gratuitos, cuja proporção geralmente é de $50 \%$ a $60 \%$ de conteúdo jornalístico e o restante de publicidade. A pressa de Kassab em ver o projeto de lei aprovado foi tanta que ele o incluiu no substitutivo do texto que criou o programa paulistano de parcerias público-privadas. Os gratuitos não aceitaram e cobraram a reversão da medida. "Parecia que o prefeito não tinha percebido a dimensão disso. Era francamente inconstitucional porque ia contra a liberdade de imprensa”, disse a este autor o diretor editorial do Destak, Fábio Santos.

Uma semana depois, em um evidente sinal de erro político, Kassab apresentou à Câmara de Vereadores um projeto de lei que retirava do projeto aprovado anteriormente as 
restrições aos diários gratuitos. Caíram tanto a imposição dos $80 \%$ de material jornalístico como o veto total a distribuir em semáforos. O texto da correção evocava justamente a Lei de Imprensa e a Constituição para garantir o direito à liberdade de imprensa.

Naquela ocasião, havia um temor dos jornais pagos de que os gratuitos pudessem competir em leitores e anúncios com seus títulos populares (o Jornal da Tarde, do Grupo Estado, e o Agora, do Grupo Folha). Como apontam as pesquisas de mercado dos gratuitos que apresentamos anteriormente, o público-alvo não é o mesmo dos populares, e pode-se notar que a linha editorial também se distancia. Exemplo: quando o $J T$ daria uma chamada de capa para o jogo Mortal Kombat? Ou, pela perspectiva contrária, não faz parte do projeto do Metro dar a lista completa de beneficiados do INSS, como o Agora costuma fazer. Como se pode atestar pelos gráficos abaixo, a circulação dos jornais pagos e o número de anúncios não sofreram grandes alterações após a chegada dos gratuitos.

Gráfico 3.3.1- Circulação media diária dos jornais pagos* (em milhões de exemplares/dia)

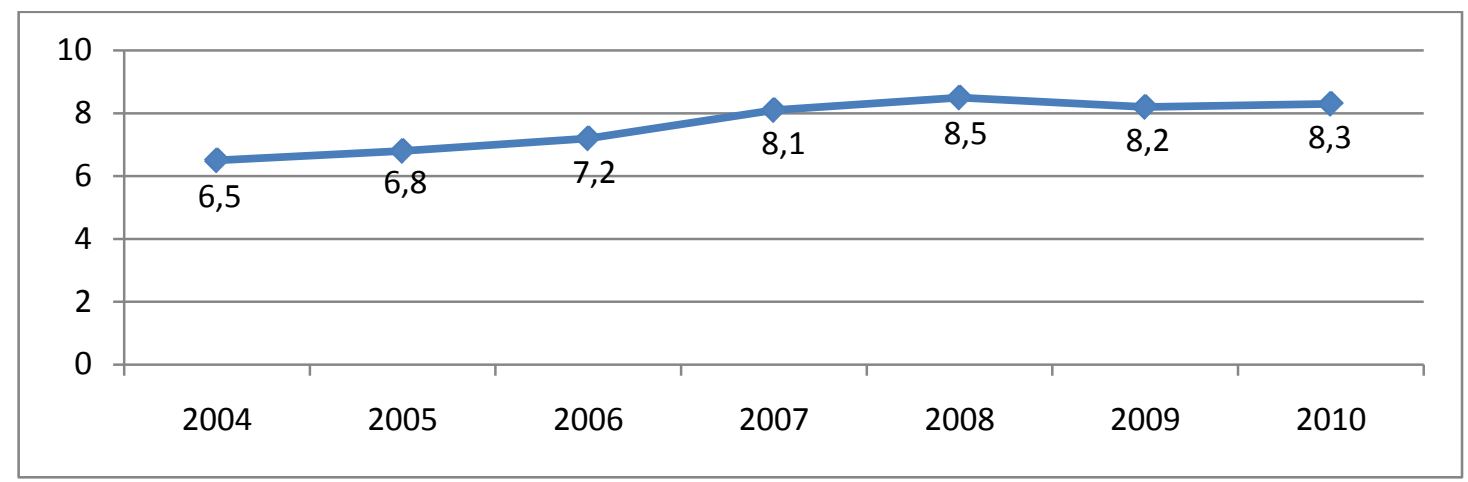

Fonte: ANJ * - estimativa para o mercado brasileiro, com base em dados do IVC

Gráfico 3.3.2 - Volume de páginas comercializadas para publicidade em jornais pagos

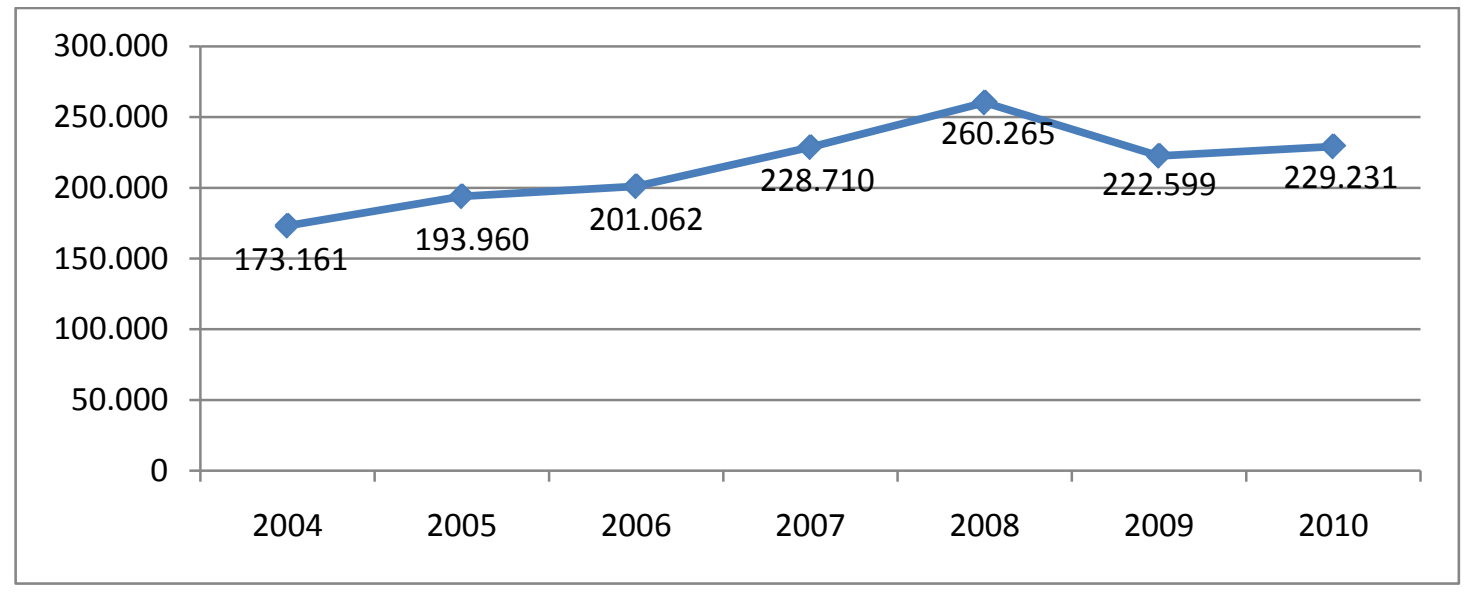

Fonte: Ibope Monitor 
Tomando como base o ano de 2006, quando o Destak chegou ao Brasil, é possível observar que a circulação dos periódicos pagos cresceu e agora passa por uma estagnação, mas seria temerário dizer que esse fenômeno se deve a alguma influência decisiva dos gratuitos. Quanto ao número de páginas vendidas para publicidade, nota-se uma queda nos últimos dois anos, mas novamente não são os gratuitos os únicos - nem os principais responsáveis por essa tendência declinante. Atualmente, a relação entre pagos e gratuitos no Brasil é de uma convivência mais ou menos pacífica, que vem se dirigindo da obstrução inicial para a coexistência, utilizando os conceitos do quadro de Picard. Os jornais pagos parecem estar convencidos de que os gratuitos não representam a ameaça que eles imaginavam. Na verdade, eles podem até ser benéficos, pelo fato de atraírem leitores que outrora tinham desistido de busca informação pelo suporte papel. E também por criarem um espaço para novos tipos de anúncio e de diálogo com a publicidade que não se via antes no mercado jornalístico brasileiro. 


\section{ANÚNCIOS PUBLICITÁRIOS E CHAMADAS DE CAPA DE METRO E DESTAK}

Neste capítulo, a pesquisa visa a comprovar toda a argumentação teórica e contextual anterior por meio da observação de seus fundamentos em elementos de anúncios publicitários e chamadas de capa dos jornais gratuitos modernos Metro e Destak. Como também já explicado previamente, a opção por destacar algumas capas do jornal Folha de S. Paulo deveu-se à ideia de usar um quality paper tradicional do mercado brasileiro para efeito de comparação com as características publicitárias dos gratuitos.

A ordem de análise das capas funcionará da seguinte maneira: primeiramente, as capas que trazem anúncios publicitários com elementos de hibridização com o discurso jornalístico. Estes exemplos serão classificados como Grupo 1. Em seguida, as capas cujas chamadas de canto superior direito fazem referência a um fato jornalístico, mas têm um forte caráter publicitário, de valorização do entretenimento. Estas farão parte do Grupo 2 de análise. Para ambos os grupos, a sequência interna seguirá o critério cronológico.

Por ordem, faremos primeiro a análise e, na página seguinte, reproduzimos uma cópia da capa analisada. 


\section{Grupo 1}

\section{Anúncio 1 - Lançamento do filme Shrek III}

Data: $15 / 6 / 2007$

\section{Veículo em que foi publicado: Destak}

Formato: vertical, meia página da capa, com elementos no cabeçalho

Cena englobante: anúncio publicitário

Cena genérica: publicidade de um novo filme

Cenografia: o anúncio retrata o ogro Shrek ao lado dos outros personagens do filme; abaixo, há uma mensagem textual de que o filme de animação Shrek Terceiro estreia hoje nos cinemas. Acima da imagem, há outra mensagem: "Hoje seu mundo e os cinemas vão ficar verdes”. Os outros elementos que funcionam como “extensão” do anúncio são um "S” verde no logotipo do jornal e uma imagem de Shrek abraçado a outros dois personagens do lado direito, fora do quadro principal da propaganda.

Aspectos polifônicos e interdiscursividade: a polifonia é observada por meio da relação dialógica entre o campo discursivo publicitário (a persuasão para assistir à estreia do filme Shrek III) e o jornalístico.

A heterogeneidade está presente em dois espaços discursivos que não fazem parte da cenografia principal do anúncio - esta segue uma fórmula até conservadora. O primeiro é o logotipo do jornal Destak, que foge do seu formato tradicional, todo em vermelho, com tipologia uniforme, e adota uma letra “S” em verde. Na verdade, trata-se do "S" característico do logo comercial do filme Shrek. É uma forma de intertextualidade por citação, uma vez que se reproduz um elemento de outro discurso de forma rigorosamente igual. Cabe, aqui, recorrer à semiótica de Charles Peirce; este "S" funciona como um símbolo do próprio personagem Shrek. Seu fundamento é um legissigno, e a relação se dá por meio de uma lei, uma abstração operativa, que age tão logo encontre um caso singular sobre o qual operar (SANTAELLA, 2002, p. 13). Isto é, o “S” verde que está no logo do Destak remete ao ogro Shrek porque assim se convencionou; não há uma relação direta de similaridade. No entanto, um símbolo nunca é uma abstração pura: o "S" traz em si elementos de qualissigno - pois o verde é a cor ícone de Shrek, cuja cor da pele é verde - e de sinssigno, já que as duas orelhinhas nas pontas do “S” operam como índice de Shrek, por reproduzirem suas próprias orelhas. A teoria peirceana desenvolveu o conceito de experiência colateral, que significa as experiências prévias do intérprete com determinado signo. Um bom exemplo de um caso semelhante é o famoso "S” da Sadia. Caso o leitor do Destak não se atenha, num primeiro momento, ao fato de que aquele "S" no logo do jornal é uma dialogia marcada com o campo publicitário, o 
espaço discursivo do anúncio principal reforça esse vínculo, ao reproduzir, em maior escala, o mesmo “S” presente acima. Para os padrões de inserção publicitária dos jornais pagos convencionais, como O Estado de S. Paulo e a Folha de S. Paulo, essa alteração no logotipo do jornal é uma medida radical. Não há nenhum registro na história desses jornais de uma campanha publicitária ter alterado a marca da instituição, como houve nesse caso do Destak.

O outro elemento dialógico é a imagem de Shrek abraçando dois personagens do desenho, disposta do lado direito do logotipo do jornal. Nesse caso, a noção de interdiscurso é essencial para captar a heterogeneidade. Quem estiver lendo pela primeira vez o Destak pode supor que essa imagem não esteja se misturando à linguagem jornalística; no entanto, o leitor habitual do jornal vai perceber que aquele espaço é destinado, normalmente, a fotos de caráter noticioso, e não comercial. A imagem de Shrek não só ocupa um espaço “estranho” à linguagem publicitária (não é comum, em jornais, abdicar desse espaço para a publicidade) como praticamente “apaga” a linguagem jornalística, ou se confunde com ela, criando um redirecionamento no olhar do leitor. 
Figura 5.1 - Reprodução da capa do Destak de 15/06/2007

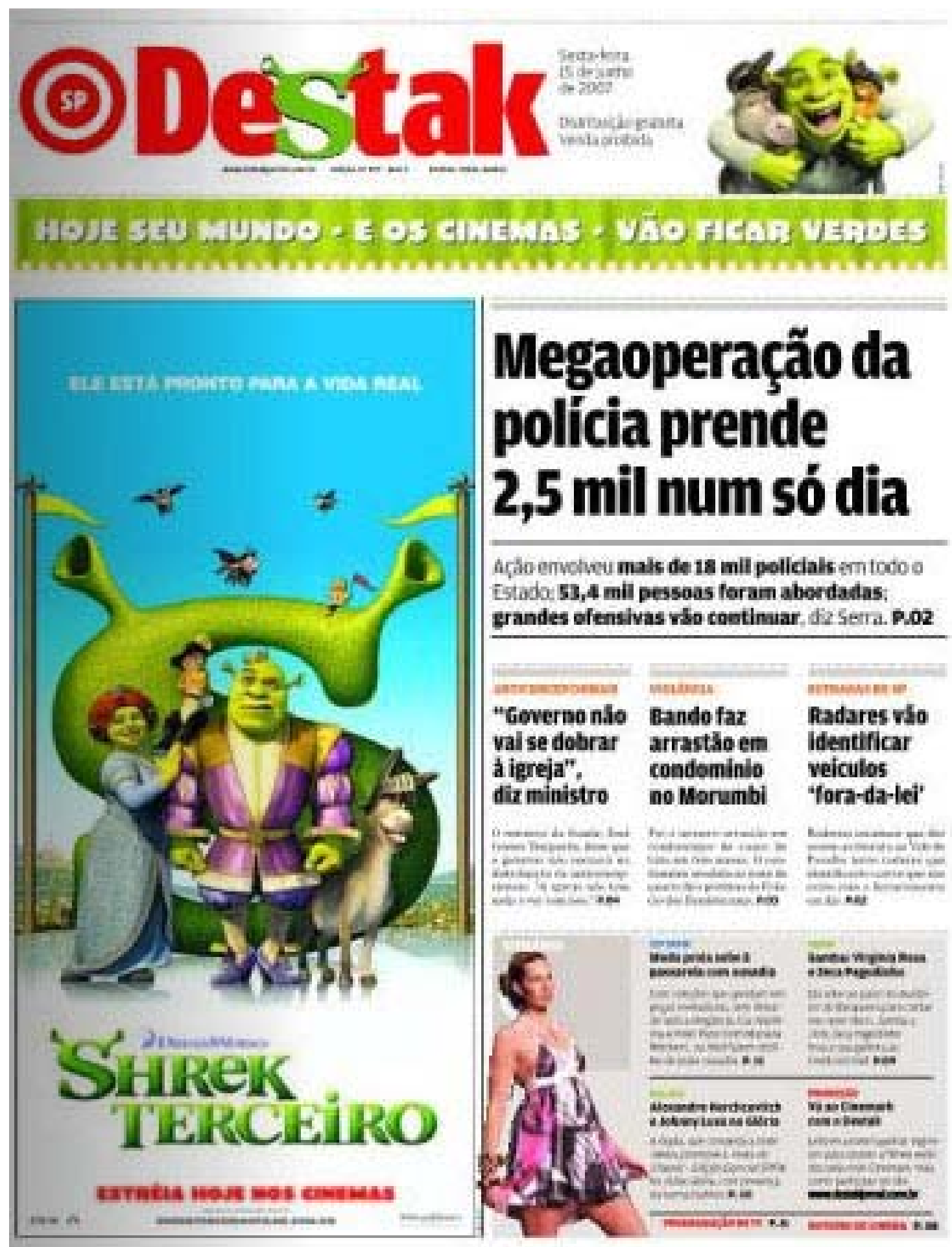




\section{Anúncios 2 e 3 - Especial "Itaucard paga as suas compras"}

Datas: 19/10/2007 e 6/12/2007

Veículos em que foram publicados: Metro (19/10) e Destak (6/12)

Formato: Sobrecapa total (quatro páginas) ${ }^{13}$

Cena englobante: anúncio publicitário

Cena genérica: publicidade de cartão de crédito, mas com muito mais elementos do discurso jornalístico do que publicitário

Cenografia: reprodução da capa de um jornal gratuito, exatamente com os mesmos formatos e disposição de manchete, fotos e chamadas de capa.

Aspectos polifônicos e interdiscursividade: a proposta do anúncio do cartão de crédito Itaucard é de uma dialogia total com o discurso jornalístico, a ponto de o hibridismo ser tanto que praticamente estão “apagadas” as referências à linguagem publicitária. A assimilação do discurso jornalístico é tal que o formato das capas do Metro e do Destak é quase integralmente reproduzido no anúncio - o tamanho da fonte da manchete e das chamadas, a foto de destaque centralizada, a imagem no topo à direita (no caso do anúncio do Destak). Somente a tipologia difere da utilizada pelos jornais, o que pode ser o primeiro sinal de estranhamento. Em uma primeira observação menos atenta, o leitor pode considerar tranquilamente que se trata mesmo da capa real do jornal. Essa imitação global de um gênero de discurso, também chamada de captação (MAINGUENEAU, 2008, p. 173), pode apenas parecer lúdica, mas em geral permite ao discurso imitador construir sua própria identidade. Pois, vejamos: após a primeira impressão visual, o leitor vai começar a ler as chamadas e se atentar para o fato de que todas fazem algum tipo de menção a episódios de sorte - mas totalmente inverossímeis, ou seja, estranhos ao discurso jornalístico. A manchete, por exemplo, é a seguinte: “Homem encontra baú de tesouro na piscina de casa”. Outros exemplos de chamadas: “Cachorro cava o jardim e descobre petróleo”; “Turista tropeça por acaso em pirâmide perdida” e "Parque ecológico do Tietê ganha 100 mil árvores”. A capa de um jornal, como gênero de discurso, respeita certas "leis do discurso", como a da sinceridade e da cooperação, em que cada parte do ato comunicacional pressupõe que o outro respeite as regras estabelecidas implicitamente. Portanto, o leitor vai inferir que tais notícias não fazem parte do discurso jornalístico, embora estejam inseridas dentro de um suporte jornalístico por excelência. É com essa aparente contradição que o anúncio do Itaucard opera para conseguir

\footnotetext{
${ }^{13}$ Embora ambas as peças publicitárias sejam sobrecapas totais, vamos analisar somente a primeira página de cada uma delas, uma vez que as demais apresentam um discurso estritamente publicitário, o que foge do objeto de nossa pesquisa.
} 
atrair seu público-alvo. De certa forma, a intertextualidade aí observada também é um tipo de estilização, pois a capa do anúncio exerce uma função paródica, subvertendo a lógica do discurso jornalístico. O leitor está acostumado a se deparar com notícias sóbrias, "sisudas” numa capa de jornal: “o PIB subiu 3\%”, “acidente mata 8”, “presidente nega crise”, etc. Ele se vê, então, só diante de notícias positivas, animadoras, com uma foto convidativa de uma linda piscina, sugerindo uma vida sem preocupações. O anúncio instiga o leitor a descobrir qual é a intenção de reproduzir uma capa com notícias fora do padrão, ou seja, ele tende a se sentir atraído por esse estranhamento decorrente de uma combinação inusitada de espaços discursivos. Só há dois elementos na página tipicamente pertencentes ao discurso publicitário: o primeiro é uma pequena faixa laranja, no cabeçalho, com os seguintes dizeres: "Edição Especial Itaucard - Publicidade”. A mensagem opera como um lembrete, ainda que muito discreto, de que a intenção última daquela página é vender um produto, por mais que não pareça isso. O segundo elemento, no pé da sobrecapa, vem no formato de uma chamada aparentemente noticiosa: “Cartão de crédito paga a compra de milhares de clientes”, seguido de um "Vire a página”. O uso da cor laranja, assim como na mensagem do cabeçalho, é na verdade um qualissigno com fins publicitários; pois o laranja é a cor-símbolo do banco Itaú, geralmente utilizado nas campanhas publicitárias da instituição. Não analisamos aqui a página seguinte do encarte, pelo fato de passar a adotar uma linguagem mais diretamente publicitária. Mas o objetivo da sobrecapa “clonada” do Destak e do Metro é associar o cliente Itaucard a uma pessoa de sorte, que pode ganhar prêmios e não tem por que enxergar a vida de modo pessimista, numa irônica referência ao próprio discurso jornalístico do qual o anúncio se vale. 
Figura 5.2 - Reprodução da sobrecapa do Metro de 19/10/2007

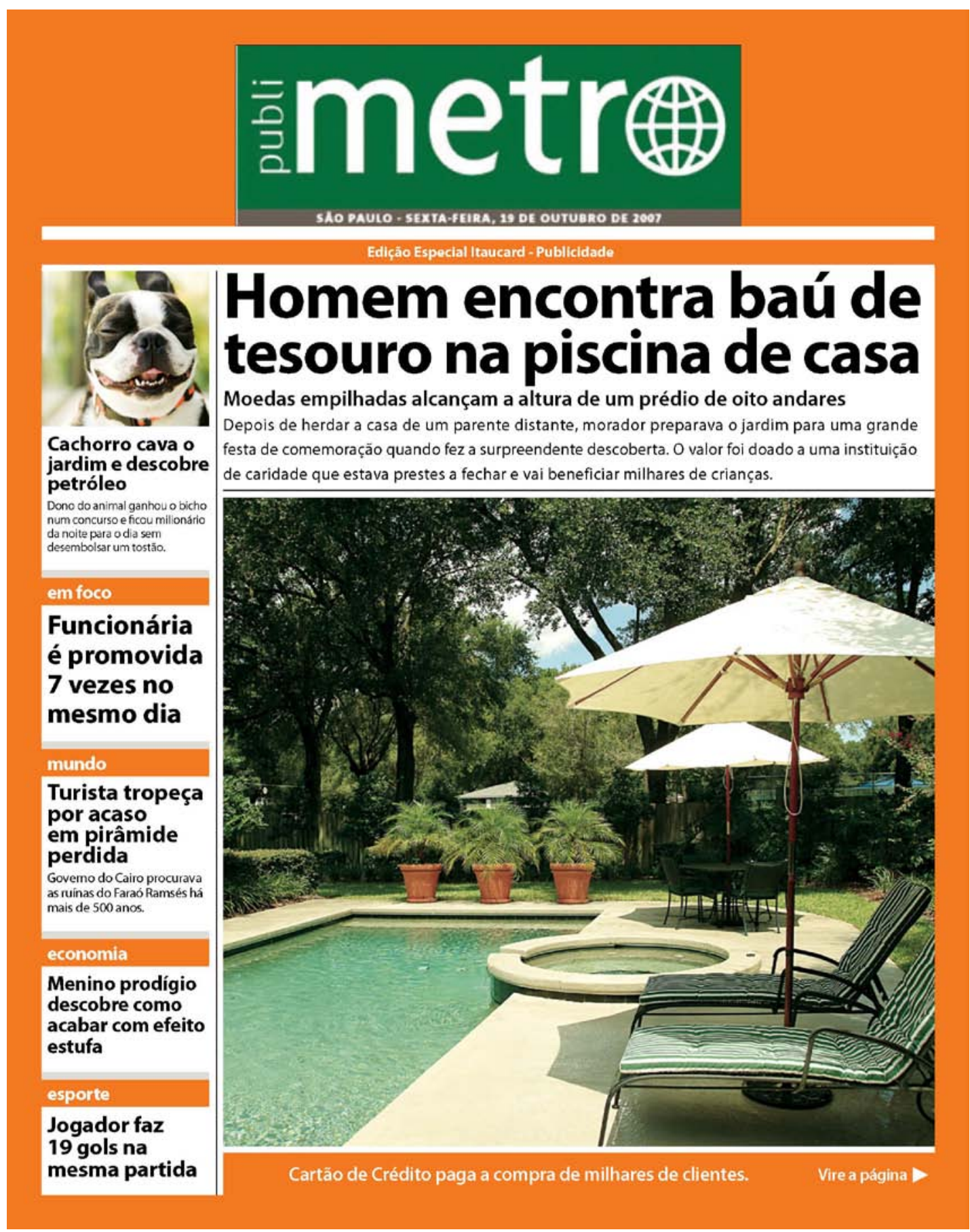


Figura 5.3 - Reprodução da sobrecapa do Destak de 06/12/2007 ${ }^{14}$

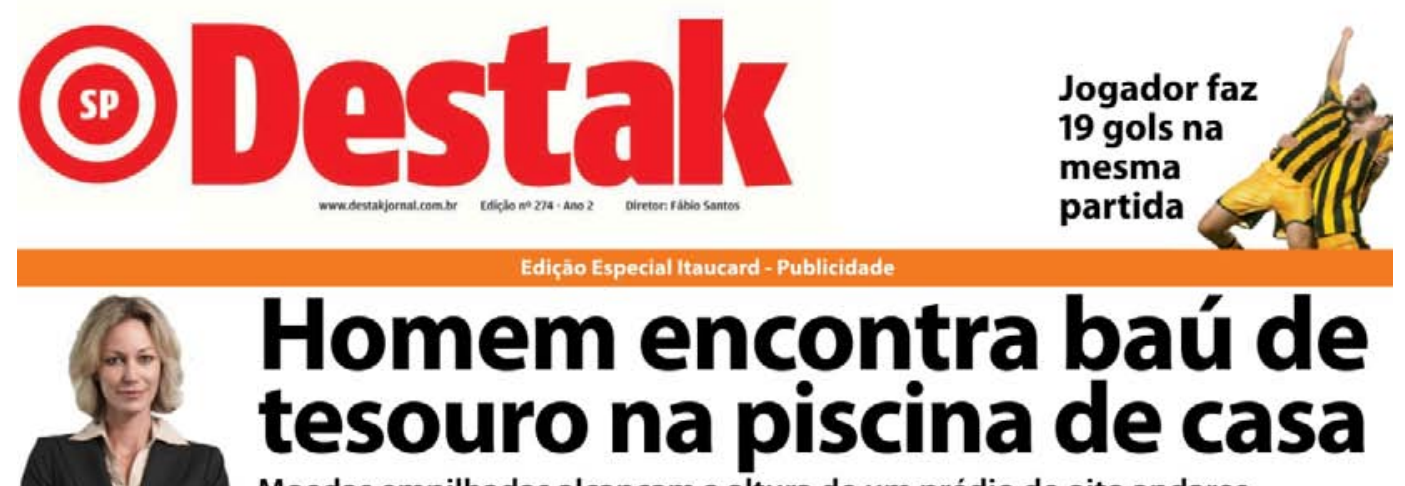

Moedas empilhadas alcançam a altura de um prédio de oito andares

Depois de herdar a casa de um parente distante, morador preparava o jardim para uma grande

Funcionária é promovida 7 vezes no mesmo dia

CARGA PESADA mundial depois da desistência de 18 competidores

\section{JORNADA}

Turista tropeça por acaso em pirâmide perdida Governo do Cairo procurava as ruinas do Faraó Ramsés há mais de 500 anos.

ECOLOGLA Parque ecológico do Tietê ganha 100 mil árvores

Cidade da sorte: moradores afimam

ter sorte sempre festa de comemoraçăo quando fez a surpreendente descoberta. O valor foi doado a uma instituiçăo de caridade que estava prestes a fechar e vai beneficiar milhares de crianças.
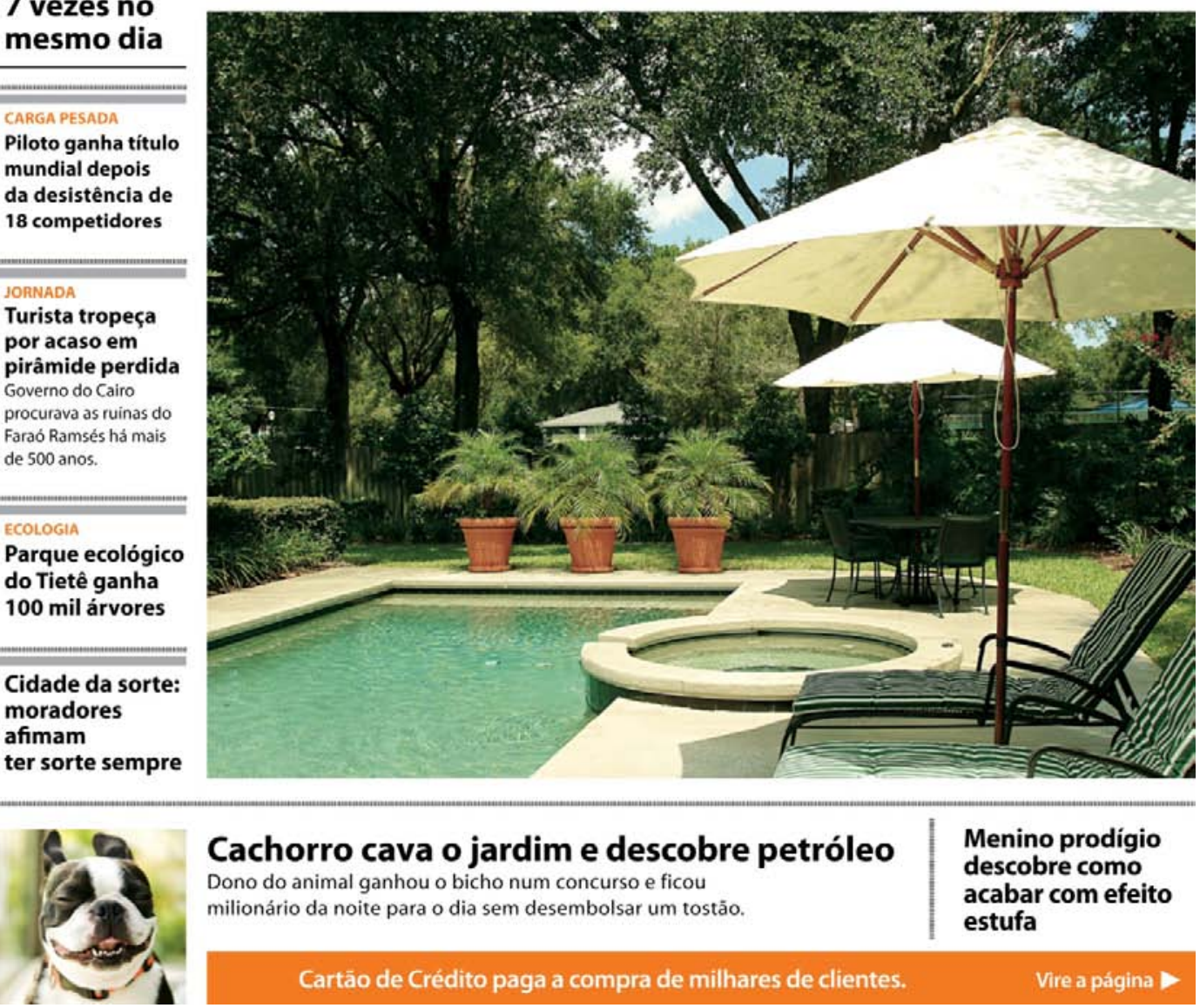

Cachorro cava o jardim e descobre petróleo

Dono do animal ganhou o bicho num concurso e ficou

milionário da noite para o dia sem desembolsar um tostão.
Menino prodigio descobre como acabar com efeito estufa

\footnotetext{
${ }^{14}$ A reprodução da capa acima não possui a data estampada ao lado do logo, como é o projeto gráfico do Destak, porque esta cópia foi obtida com a agência de publicidade DPZ, responsável pela campanha. Trata-se de uma versão não-datada que foi enviada à redação do Destak para apreciação
} 


\section{Anúncio 4 - A grande oferta misteriosa da Loja Unidas/Sherlock Rodas}

Data: $16 / 5 / 2008$

Veículo em que foi publicado: Destak

Formato: sobrecapa total (quatro páginas)

Cena englobante: anúncio publicitário

Cena genérica: publicidade de uma promoção de carros seminovos

Cenografia: na capa, informa-se que um “detetive famoso” está com uma missão no Itaim Paulista (bairro da zona leste de São Paulo): descobrir o paradeiro de uma oferta desaparecida da nova loja de carros seminovos Unidas no bairro. Na segunda página, a história do desaparecimento é detalhada. Na terceira, o tal detetive, chamado Sherlock Rodas, “entrevista” alguns carros que podem servir de testemunha para elucidar o mistério. Na última página, o próprio Sherlock Rodas dá uam entrevista exclusiva para dizer como solucionou o caso da Unidas do Itaim Paulista.

Aspectos polifônicos e interdiscursividade: o anúncio utiliza um formato publicitário tradicional e nobre em veículos impressos, a chamada sobrecapa. Logo na primeira página, a mensagem-fim da peça é anunciada: “Nova loja de seminovos Unidas abre em Itaim Paulista”. Mas a frase continua da seguinte maneira: “com superoferta desaparecida”. Há uma dialogia do discurso publicitário com outros dois: o jornalístico e o literário. Para facilitar a análise, vamos dividir o anúncio pelo número de páginas.

Capa e página 2: a assimilação do discurso jornalístico pelo anúncio é a de mais fácil observação. O título funciona como uma "manchete” de jornal, embora claramente estilizado e com termos estranhos ao repertório jornalístico para que não reste nenhuma dúvida de que estamos falando de um anúncio: “Extra. Detetive famoso em missão no Itaim Paulista.” E abaixo aparecem as "chamadas" ou "submanchetes" do fato extraordinário, com as respectivas remissões às páginas do encarte, tal como o rito do espaço discursivo de uma capa de jornal. A dialogia se faz de maneira um tanto paródica, numa intertextualidade por estilização, que não chega a ser negativa. Isso se observa no uso da palavra “extra”, que não se enquadra mais no discurso jornalístico atual, e na própria tipologia utilizada pelo anúncio, que talvez se assemelhe a antigos veículos sensacionalistas. $\mathrm{O}$ interdiscurso publicidade/literatura se dá pela referência a "Sherlock Rodas", outra intertextualidade paródica com o personagem Sherlock Holmes, criado pelo escritor britânico Arthur Conan Doyle e famoso por solucionar os mais complexos crimes. Recorrendo outra vez à semiótica peirceana, a reprodução da boina que se tornou um ícone da imagem do detetive reforça o aspecto intertextual, além da lupa. 
Página 3: a dialogia, nesta página, é restrita aos discursos publicitário e literário. Sherlock Rodas começa a buscar pistas sobre o possível destino da superoferta desaparecida e pergunta a alguns outros carros da loja quando foi a última vez que eles viram a “vítima”. Os diálogos se dão em forma de história em quadrinhos. O vínculo com a publicidade está na apresentação dos carros “ouvidos”, como se fosse uma espécie de legenda: são informados o modelo do veículo, ano de fabricação, outras especificações e, por fim, o preço. Aliás, este é o único espaço discursivo do encarte em que há um discurso publicitário “puro”, sem hibridizações com nenhuma outra linguagem.

Página 4: na "entrevista exclusiva” com Sherlock Rodas, a dialogia com o discurso jornalístico é marcada. Além de se valer de um gênero discursivo típico do jornalismo (a entrevista), o anúncio ainda utiliza o nome do jornal Destak nas perguntas ao fictício entrevistado. A formulação das questões feitas pelo suposto repórter do Destak segue uma lógica de discurso jornalístico (são objetivas e não possuem nenhum apelo comercial) e mesmo as frases de Sherlock Rodas escolhidas para entrar no "olho" - espaço discursivo jornalístico que dá destaque às opiniões mais interessantes do entrevistado - não contêm uma mensagem comercial direta. $\mathrm{O}$ anúncio tenta se associar à imagem de credibilidade do discurso jornalístico e do próprio veículo noticioso para atrair o consumidor. O único elemento da página que remete explicitamente a um informe publicitário é o logo da Unidas, no canto direito inferior. 
Figura 5.4 - Reprodução da sobrecapa do Destak de 16/05/2008

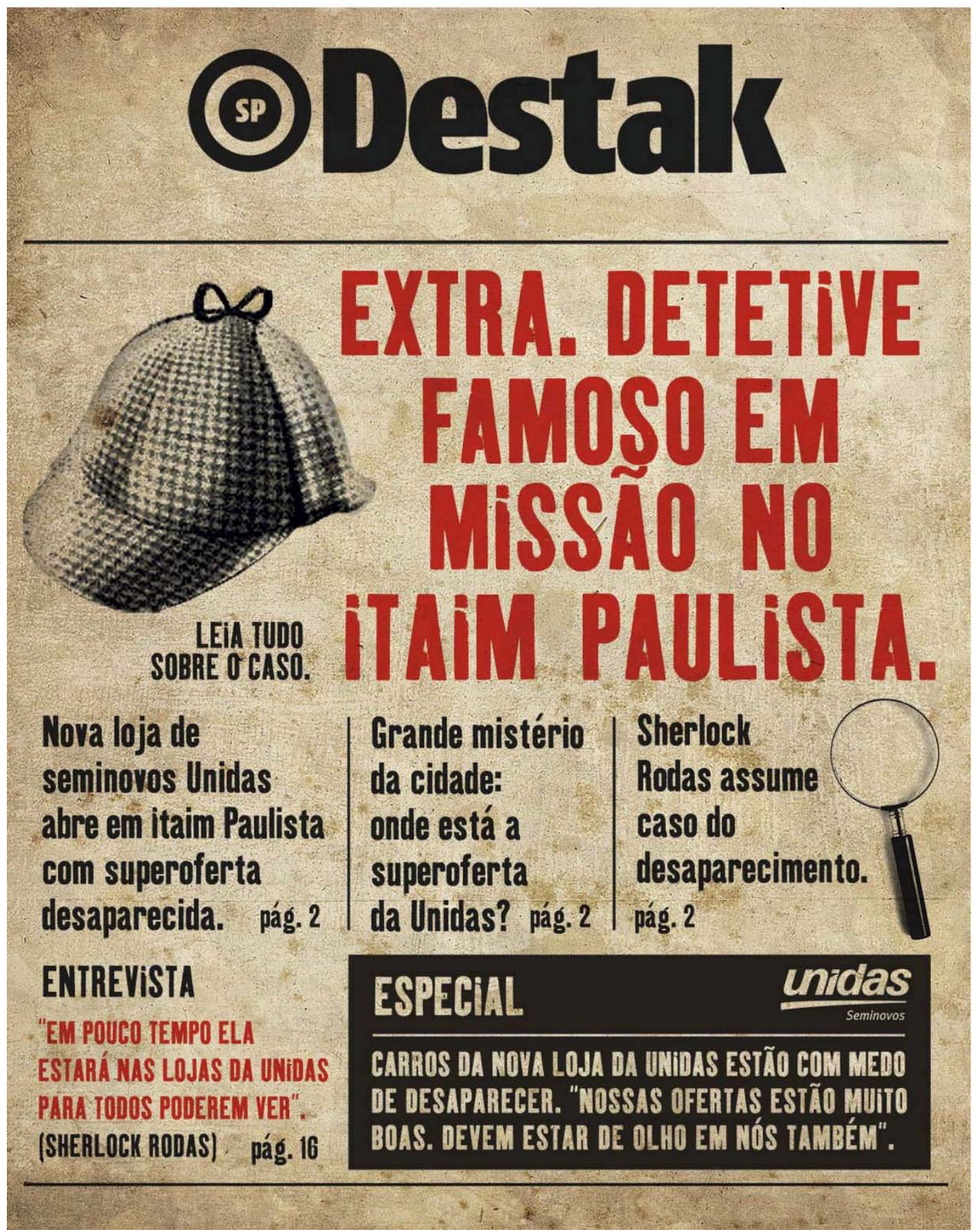


Figura 5.5 - Reprodução da página 2 do anúncio no Destak de 16/05/2008

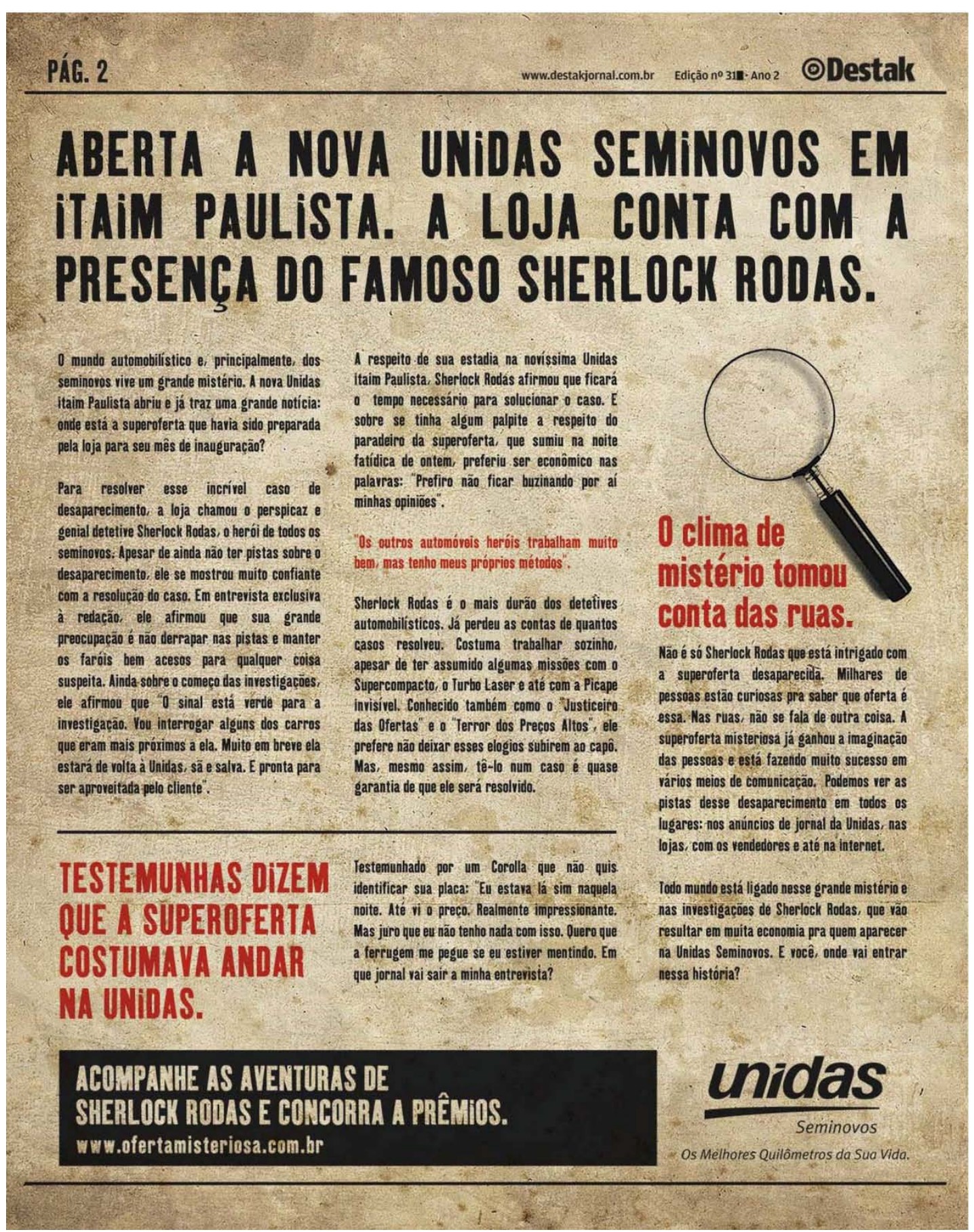


Figura 5.6 - Reprodução da página 3 do anúncio no Destak de 16/05/2008
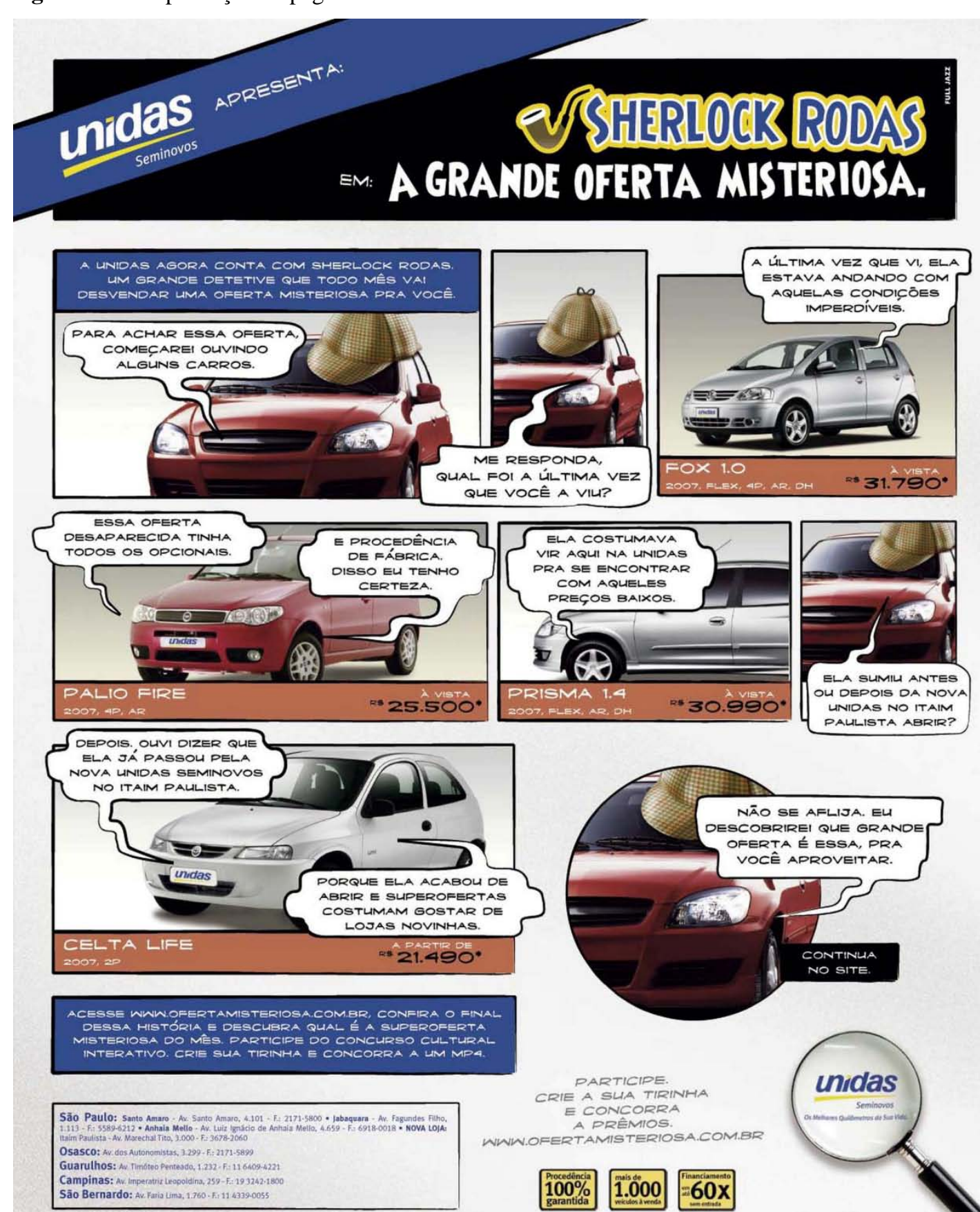

WWW.OFERTAMISTERIOSA.COM.BR

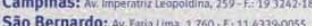

Procedincia
$100 \%$
garantida

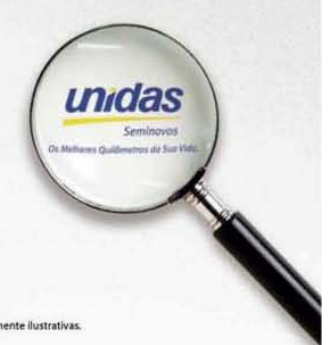


Figura 5.7 - Reprodução da página 4 do anúncio no Destak de 16/05/2008

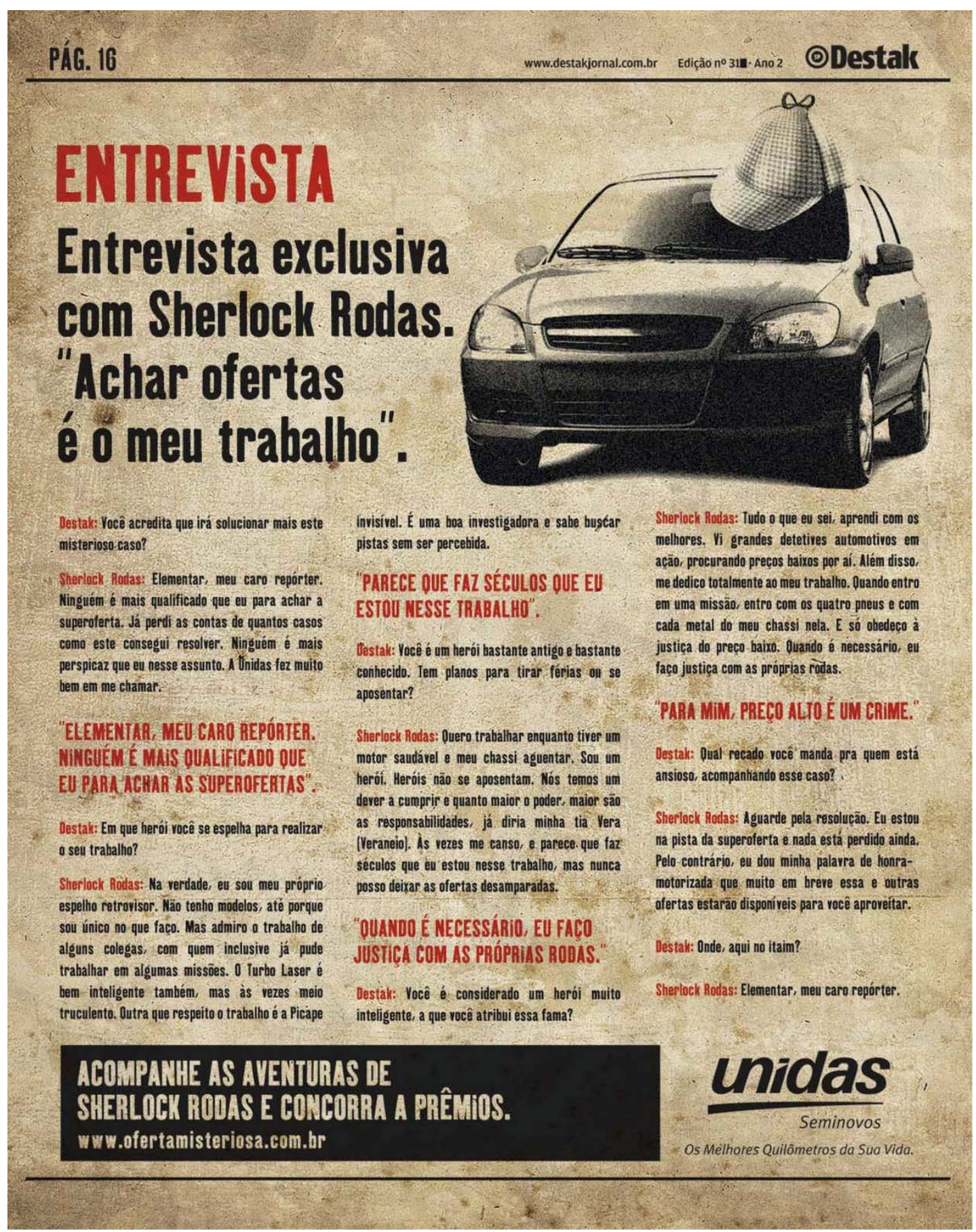




\section{Anúncio 5 - Esso e Mobil na Stock Car}

Data: 27/3/2009

Veículo em que foi publicado: Destak

Formato: encarte

Cena englobante: anúncio publicitário

Cena genérica: publicidade do combustível Esso e do óleo Mobil para a competição Stock Car

Cenografia: difusa; reprodução de uma capa do jornal Destak com manchete e chamadas referentes à prova da Stock Car em São Paulo e aos produtos Esso e Mobil, com impressão sobre um tecido de flanela

Aspectos polifônicos e interdiscursividade: este anúncio possui uma maior complexidade em relação ao imbricamento do discurso publicitário com o jornalístico, mais especificamente com o campo discursivo dos jornais gratuitos. O aspecto cenográfico que mais chama a atenção nesta peça publicitária é, sem dúvida, o material de que é feito: tecido de flanela para limpar vidros de carros. "Uma modificação do suporte material de um texto modifica radicalmente um gênero de discurso.” (MAINGUENEAU, 2008, p. 68). Na flanela está impressa uma reprodução da capa do Destak, seguindo o mesmo modelo do anúncio do Itaucard analisado anteriormente. A manchete traz a seguinte informação: "Stock Car acelera em São Paulo", acompanhada da linha-fina "Temporada 2009 da maior categoria do automobilismo brasileiro começa no próximo domingo em Interlagos, com novos patrocinadores: Esso e Mobil” Os trechos em negrito assim o estão na peça publicitária. Observam-se, dentro do mesmo período e pelos destaques dados a cada trecho, elementos do discurso jornalístico e publicitário: pode ser de interesse jornalístico afirmar que a temporada de Stock Car começa naquele domingo (provavelmente a maioria dos jornais noticiou isso na ocasião), ao passo que cabe ao discurso publicitário citar os patrocinadores da temporada. É evidente que o suporte da flanela já deixa claro ao leitor que aquela não é a capa verdadeira do jornal - pela lei da cooperação, não se espera de um jornal que imprima sua capa em um material destinado convencionalmente a outro fim completamente diverso. No entanto, dentro do espaço discursivo estritamente textual, o anúncio pretende estabelecer um hibridismo entre os dois discursos, ao menos na manchete. Das chamadas da capa, a que explicita o discurso publicitário é a do pé da página, onde se lê: "Esso e Mobil são as fornecedoras oficiais de combustível e lubrificantes para todos os carros da Stock Car 2009”. Está dada, de forma bastante direta, a mensagem que o anúncio pretende passar. E o reforço está no topo à direita, com uma propaganda convencional da Esso dentro do formato de uma capa real do Destak. 
Boa parte das chamadas de capa restantes faz oportuna referência ao automobilismo (“Conheça as gírias e os termos usados pelos pilotos”; "Dúvidas sobre o que levar para o autódromo no dia da corrida?”; “Corrida atrai turismo e investimentos para a capital” etc), mas outras, com a intenção de respeitar as seções habituais do jornal “real”, empobrecem a relação de heterogeneidade por conta do conteúdo pouco criativo e inverossímil dentro do discurso jornalístico. Exemplos: “Saiba tudo o que está acontecendo na sua cidade” ou "Fique por dentro do que acontece com o seu dinheiro e muito mais”. O diferencial do anúncio é mesmo o suporte: qual leitor-consumidor não vai se sentir atraído por apanhar o jornal ao se deparar com um encarte tão inusitado? As duas “páginas” do meio não possuem nenhum texto impresso, ou seja, formam tão só uma flanela. Aí reside mais uma relação dialógica, esta ligada não tanto ao discurso jornalístico em sentido amplo, mas sim ao espaço discursivo assumido pelos jornais gratuitos. Tanto o Destak quanto o Metro são distribuídos majoritariamente em cruzamentos de grandes avenidas de São Paulo. Logo, o principal alvo são os motoristas de carro. Qual público seria potencialmente melhor que este para receber um encarte publicitário que pode se transformar em um pano para limpar os vidros do automóvel? O público que anda de carro tem mais chances de se interessar por um anúnciobrinde ligado ao automobilismo. Uma flanela chama a atenção tanto visualmente quanto em relação ao tato, especialmente para quem está de alguma forma relacionado ao universo automobilístico.

\footnotetext{
Os recursos sinestésicos precisam relacionar o espectador à mensagem, seja de maneira literal ou por metáforas, pois de nada adianta instigar a curiosidade do público se ele não compreender a relação do elemento inusitado com a informação, o que pode causar frustração e prejudicar a imagem do anunciante bem como a fixação da mensagem, que seria reforçada pelos diferenciais da forma. (CHIMINAZZO, 2008, p. 477)
}

A argumentação acima faz parte da preocupação do anúncio publicitário, que deixa de lado a dialogia com o discurso jornalístico e parte para a transmissão direta da mensagem publicitária na contracapa do encarte: “A gente não cuida só do seu carro. Esso, o único combustível de todos os carros do Stock Car.” O que se quer passar ao leitor-motorista do Destak é o seguinte: motorista, estamos dando de brinde esta flanela para cuidar do seu carro, mas lembre-se que temos exclusividade no abastecimento dos carros da Stock Car. Esta informação tenta passar uma imagem de credibilidade do combustível Esso em qualquer situação, seja nas ruas ou nas pistas. É uma forma de garantir que a mensagem seja fixada e reforçada pelo caráter diferencial da forma do anúncio. 
Diários gratuitos Destak e Metro no Brasil - Juliano Machado

Figura 5.8 - Reprodução da sobrecapa do Destak de 27/03/2009 15

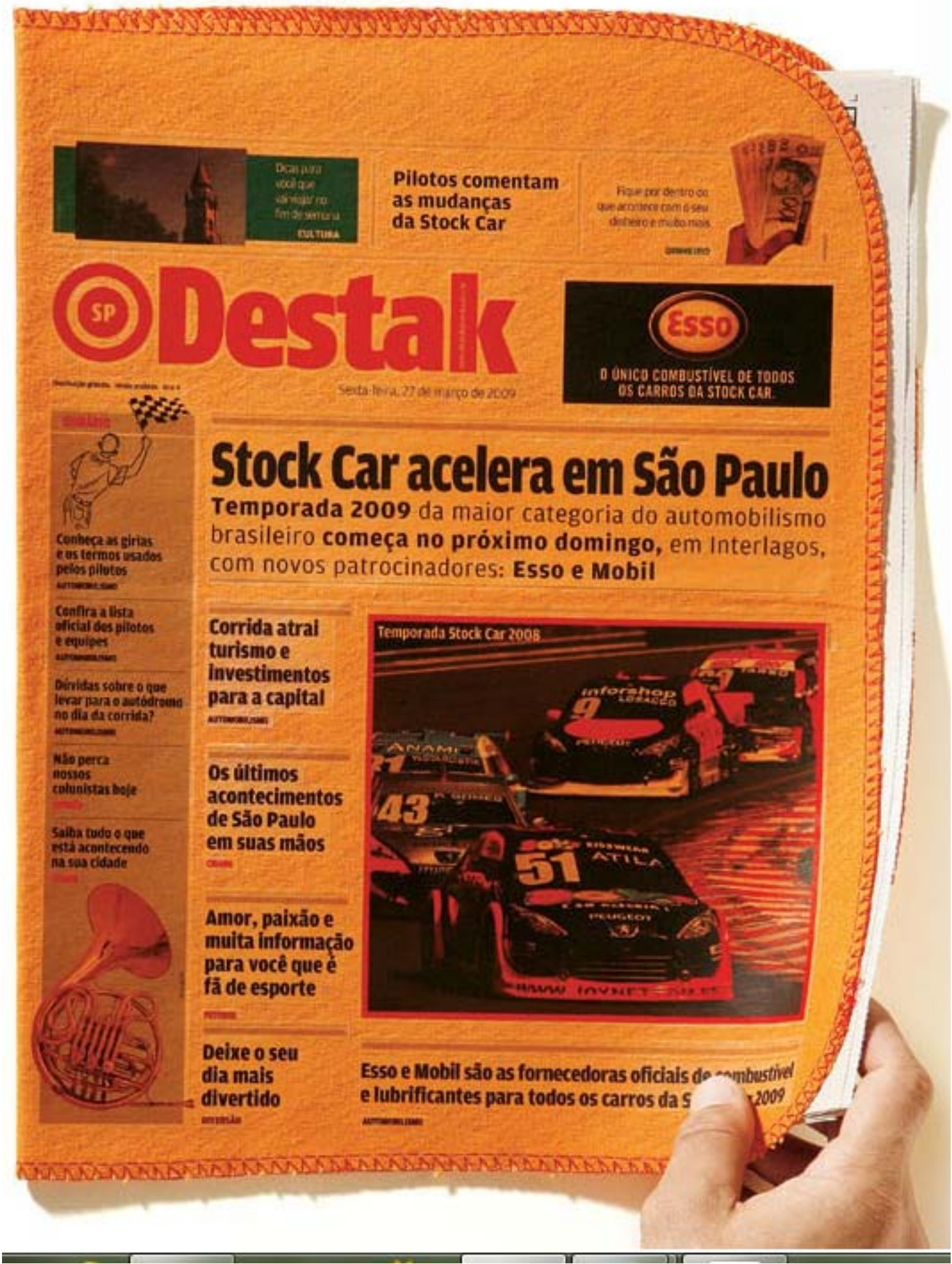

${ }^{15}$ Reprodução retirada da internet 
Diários gratuitos Destak e Metro no Brasil - Juliano Machado

4. Anúncios Publicitários e Chamadas de Capa de Metro e Destak

Figura 5.9 - Reprodução da contracapa do Destak de 27/03/2009 16

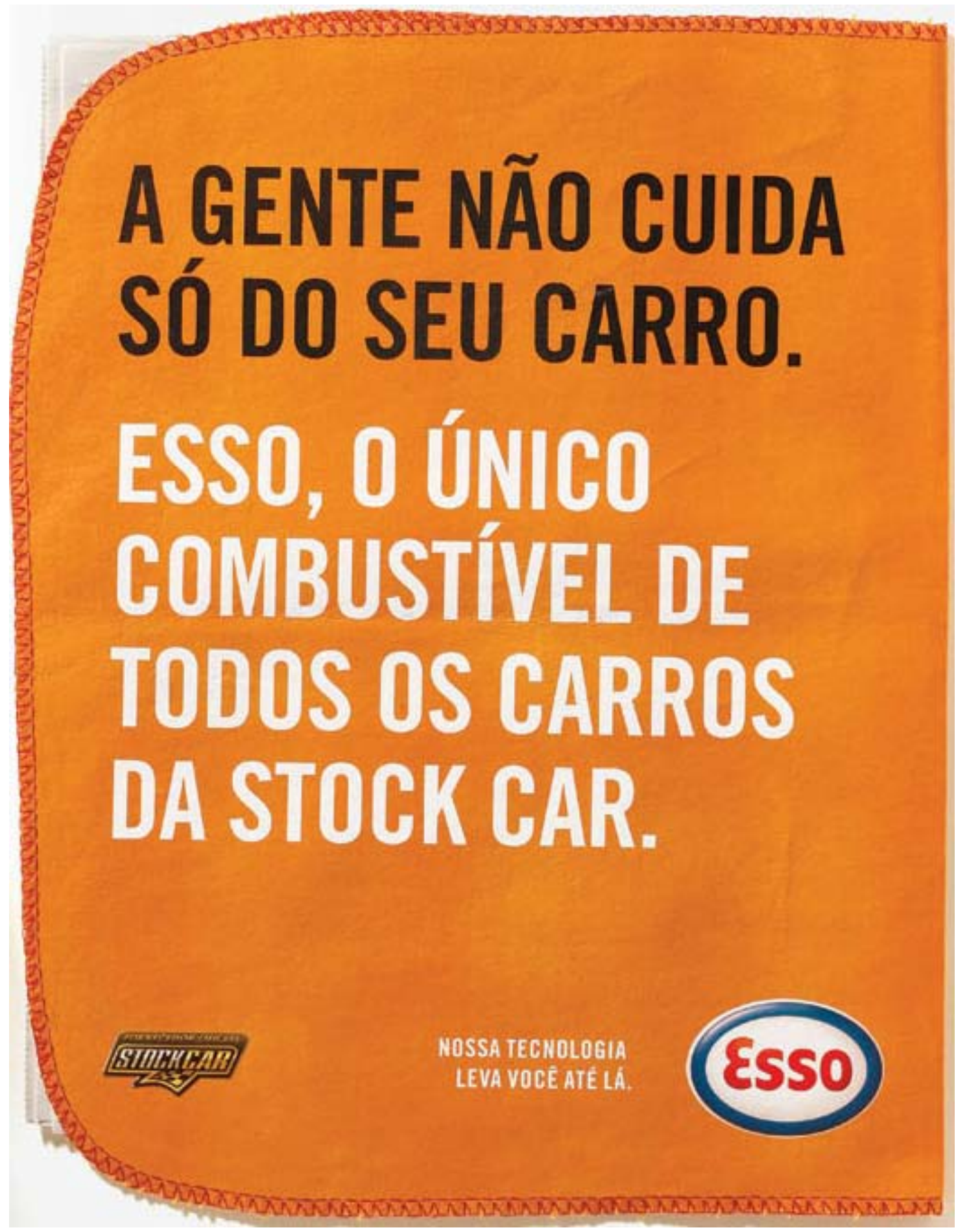

${ }^{16}$ Reprodução retirada da internet 


\section{Anúncio 6 - Curso de inglês Yázigi}

Data: $7 / 2 / 2011$

\section{Veículo em que foi publicado: Metro}

Formato: Sobrecapa total (quatro páginas) ${ }^{17}$

Cena englobante: anúncio publicitário

Cena genérica: publicidade de um curso de inglês

Cenografia: de forma difusa, trabalha no plano textual tanto com a publicidade tradicional, de forma direta, quanto com a linguagem publicitária incitativa. No plano imagético, usa o discurso jornalístico (ou a falta dele) em uma capa de jornal gratuito para causar surpresa

Aspectos polifônicos e interdiscursividade: não é preciso ser um estudioso de comunicação para concluir que os dois elementos indispensáveis em uma capa de jornal são texto e foto. Se um dos dois não está presente em sua totalidade, não há apenas uma sensação de estranheza. Passa-se quase a ter a certeza de que houve uma falha operacional, não permitindo a publicação do enunciado que deveria estar em seu lugar, de acordo com o princípio da cooperação, um dos pilares das leis do discurso (MAINGUENEAU, 2008, p. 32). Por esse princípio, o coenunciador leva em conta a ideia de que o enunciador/jornalista também conhece essa regra do jogo princípio e que, se não lhe deu nenhuma razão para duvidar de que vá cumpri-la, é porque há algum elemento que foge a suas expectativas prévias. No ano passado, a edição de 9 de agosto do caderno Metrópole, de $O$ Estado de $S$. Paulo, foi publicada sem manchete, mas com um texto jornalístico correndo normalmente abaixo e nenhum outro indício de que pudesse ser um anúncio publicitário. A dúvida sobre o que era aquilo durou até o dia seguinte, quando a direção do jornal pediu desculpas em uma nota, afirmando que houvera "um problema técnico” - diante das circunstâncias apresentadas ao leitor/coenunciador, só podia ser esta a causa para uma quebra tão grande do contrato. É neste contexto comunicacional que opera, em um primeiro momento, o anúncio do curso Yázigi. Quem vê de longe a capa do Metro desse dia simplesmente se depara com imagens sem nenhum texto, embora os espaços para as manchetes e chamadas estejam lá, respeitados em sua disposição gráfica. Ao aproximarmos a vista, porém, percebemos que não se trata de um erro gráfico. No alto da página, o aviso “INFORME PUBLICITÁRIO”, em letras

\footnotetext{
${ }^{17}$ Embora o anúncio publicitário seja uma sobrecapa total, analisaremos apenas a primeira página, uma vez que as demais apresentam só o discurso puramente publicitário, o que foge de nosso interesse
} 
maiúsculas, cumpre a função de reordenar o princípio da cooperação do discurso. O leitor passa a pensar: “com essa informação, sei que o anúncio pretende passar algum tipo de mensagem ao retirar todos os textos da capa, mas qual exatamente?”. Sem causar uma nova quebra de expectativas, o anúncio responde à pergunta na parte de baixo da capa. Um quadro cujo formato remete a elementos da publicidade traz o logo do Yázigi à direita e a seguinte mensagem à esquerda: "É assim que se sente quem não fala inglês no mundo de hoje”. Na capa verdadeira do Metro, lá estão as letras de volta (a reprodução está logo após a sobrecapa). Além da evidente dialogia por meio da reprodução fiel do formato de uma capa do Metro, o anúncio se vale de uma incorporação metafórica do discurso jornalístico quando este se atribui a função de ponte entre seu público-alvo e uma determinada concepção de mundo. Mais ou menos na seguinte linha de raciocínio: se você não aprender a falar inglês, terá uma dificuldade de se relacionar com o mundo tão grande quanto a sensação de ver uma capa de jornal como se nela houvesse apenas fotos, pois você não consegue ler o texto. Em geral, como vimos em nossa fundamentação teórica, o discurso publicitário costuma suavizar a agressividade intrínseca de sua finalidade comercial com recursos textuais e estilísticos que o desobrigam a recorrer a enunciados imperativos. O anúncio da Yázigi é interessante porque subverte um pouco essa lógica. Não há nenhuma mensagem como "Estude inglês" ou “Comece agora”, mas o efeito causado pela frase no quadro com a capa sem nenhuma palavra nos parece muito mais ameaçador e impositivo do que uma convocação para se matricular. Ao mesmo tempo que dissimula a intenção final do anúncio, ele a reforça de maneira inovadora. 
Diários gratuitos Destak e Metro no Brasil - Juliano Machado

Figura 5.10 - Reprodução da sobrecapa do Metro de 07/02/2011

BRASP_2011-02-07_capas01e04. gxp : ERAZIL 2/6/11 9:43 PM Page 3

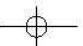

INFORME PUBLICITÁRIO

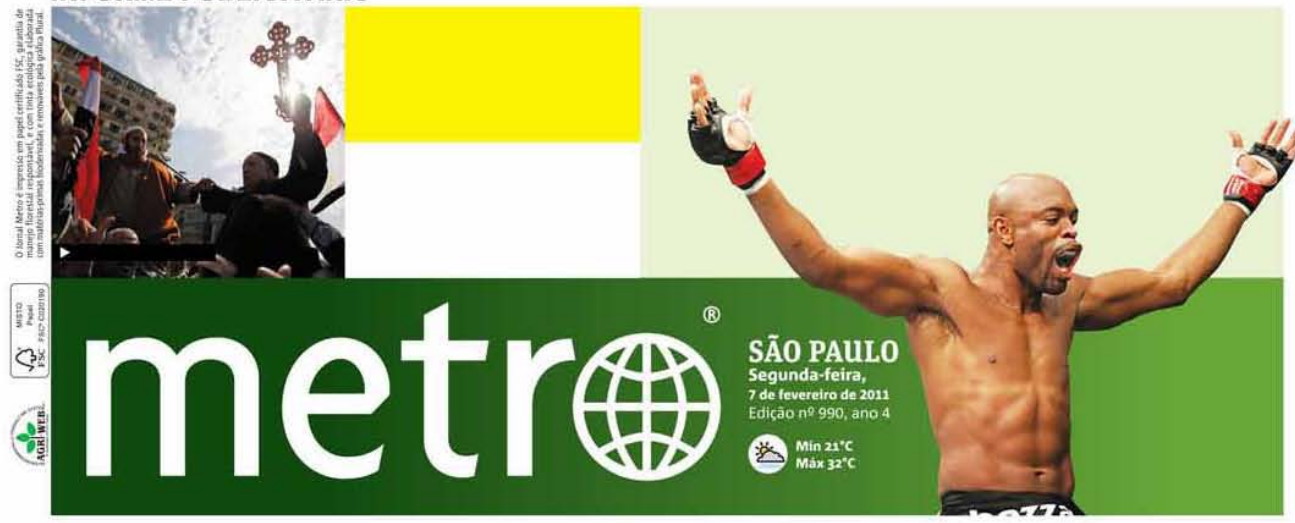

$\emptyset$

(

(

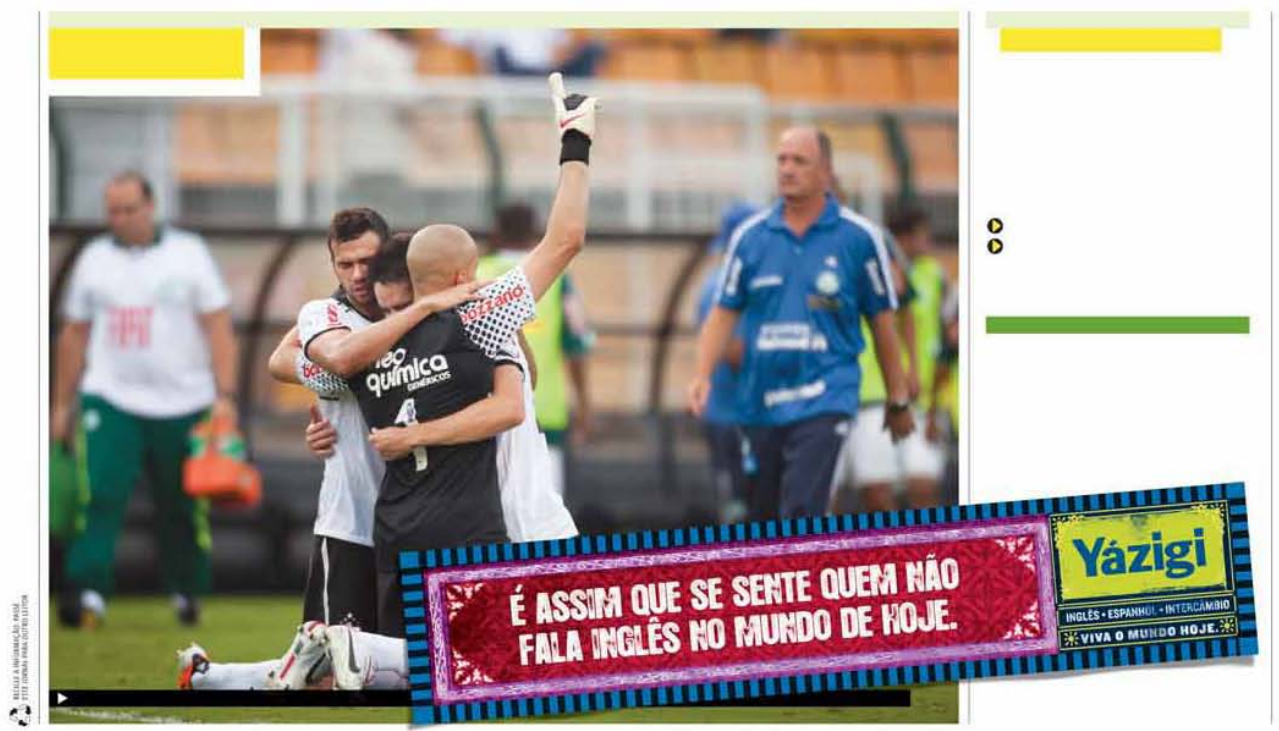


Figura 5.11 - Reprodução da capa do Metro de 07/02/2011

BRASP_2011-02-07_1. Gxp: BRAZIL 2/6/11 $9: 13$ PM Page 1
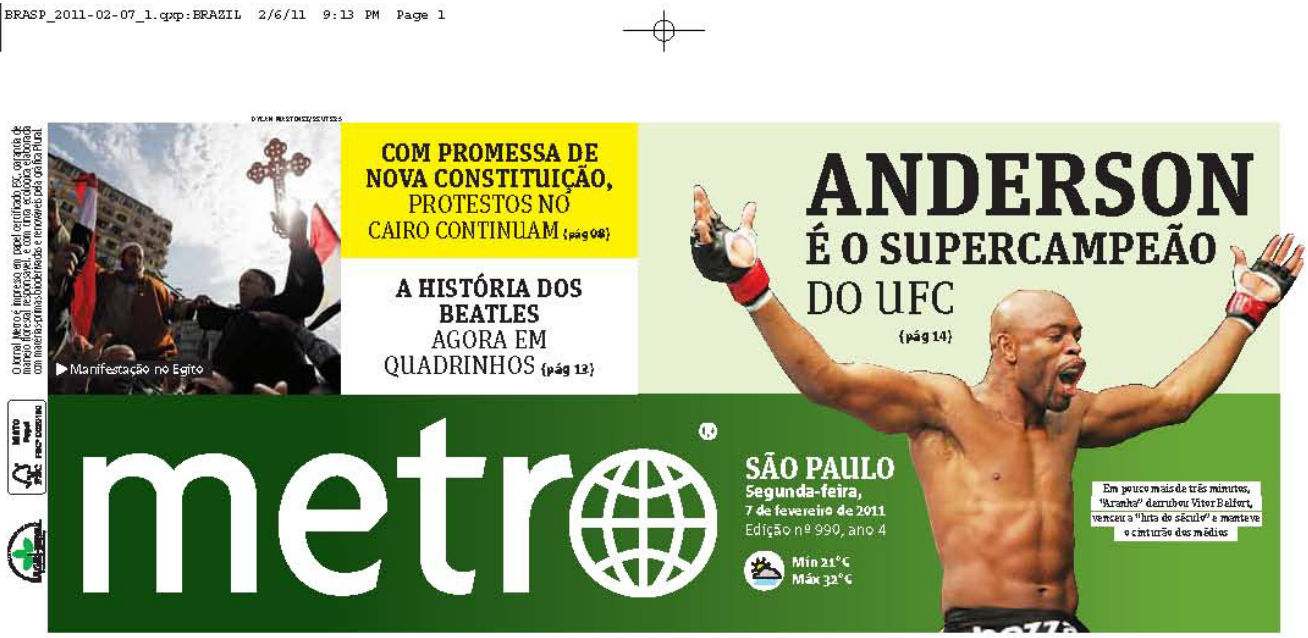

\section{Maioria dos adolescentes começa a beber em casa}

O Em $46 \%$ dos casos, parentes säo os responsáveis por oferecer primeira dose aos jovens; amigos vêm em segundo lugar, com $28 \%$ Pesquisa da unifesp ouviu estudantes de 37 escolas particulares da cidade \{págo2\}

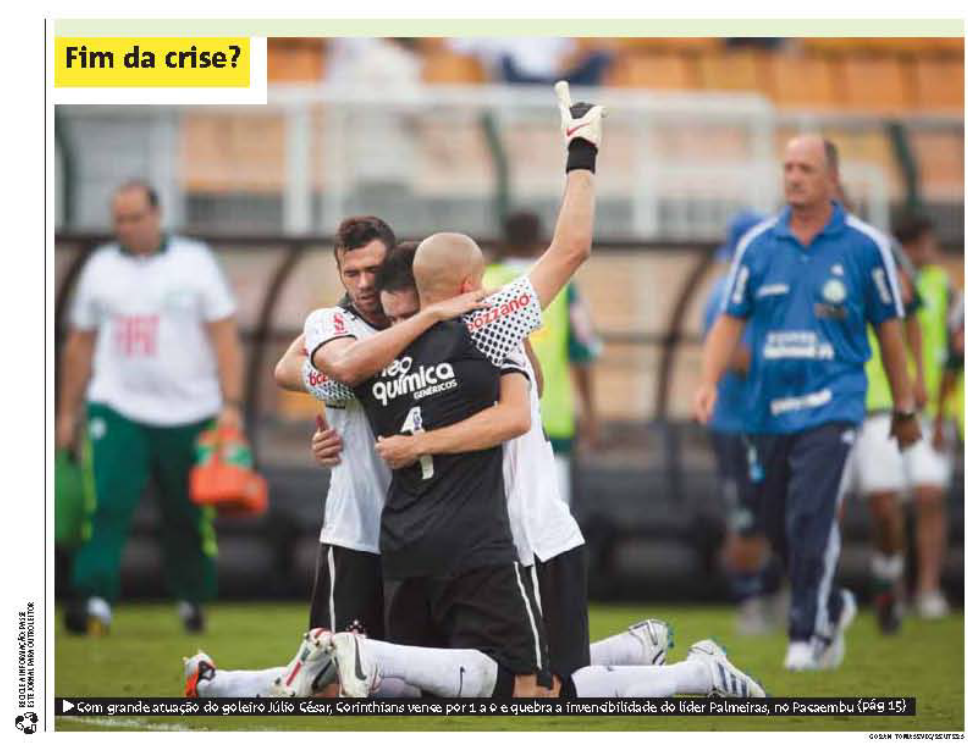

Em foco
Ruído já
reprova carro
na inspeção
Oregra vale para 2011
O Secretârio do Meio Ambiente
quer vistoria ammbiental de
veículos em todo o Estado \{́nág out

PM retoma nove favelas no Rio

D Com apoio da Marimha, Bopee Policia Civil ocuparam morros dos complexos Sảo Carlos e Santa Tereza em 2 horas fpág oo

Tablet pode ficar mais barato O Miristro das Comuricaçôes diz que governo estuda reduzir im- 


\section{Anúncio 7 - Curso de inglês Red Balloon}

Data: 20/6/2011

\section{Veículo em que foi publicado: Folha de S. Paulo}

Formato: sobrecapa

Cena englobante: anúncio publicitário

Cena genérica: publicidade de um curso de inglês

Cenografia: difusa, muito semelhante à do anúncio anterior (Yázigi), com reprodução fac-símile da capa de um jornal e um formato clássico de anúncio publicitário no pé da página

Aspectos polifônicos e interdiscursividade: o roteiro da construção de sentido deste anúncio é praticamente igual ao que analisamos imediatamente antes. A dialogia com o discurso jornalístico é evidentemente marcada, na explícita apropriação da capa da Folha, com uma intacta disposição de chamadas, manchetes, fotos e outros elementos. Se a sensação de estranhamento não é imediata quanto olhar de longe uma capa apenas com fotos e buracos faltando texto, é tão ou mais intensa que a primeira pelo fato de quase todos os enunciados estarem escritos em inglês - com exceção ao cabeçalho e aos “chapéus”, como são conhecidas no jargão jornalístico as palavras-chave que se referem a uma editoria ou resumem o assunto da nota em questão. Em vez da manchete "Benefício fiscal não é controlado, aponta TCU”, o que se lê é "Tax benefit is not controlled, said TCU”. Em tempos globais e com o Brasil ocupando um espaço crescente na política internacional, estaria a Folha trazendo uma inovação ao lançar uma versão impressa na língua universal? Não seria uma suposição impertinente para os leitores do periódico, uma vez que a Folha.com, versão online da publicação, traduz algumas notícias para o inglês. Mas voltemos às leis do discurso e ao princípio da cooperação: se essa novidade realmente estivesse chegando às bancas naquele dia, o produtor das notícias teria de avisar seu coenunciador a tempo de evitar surpresas que atravanquem o fluxo da enunciação. Logo, se não há manifestação editorial em relação a esse fato, permite-se ao leitor partir para a hipótese de um anúncio - o que o tradicional enunciado “INFORME PUBLICITÁRIO”, em vermelho e acima do nome do jornal, trata de esclarecer. Assim como no exemplo do Yázigi, a lógica desse anúncio é a de "recuar” no grau de hibridismo e oferecer ao leitor um mecanismo pelo qual seja possível fazer uma mínima diferenciação entre os discursos publicitário e jornalístico, até para que ele possa entender o efeito pretendido. É para isso que serve o quadro no rodapé, cuja disposição na página e formato também são os mesmos do anúncio da capa verdadeira, como se pode ver na figura 5.13. O enunciado do quadro diz: "Não tá entendendo nada? Peça pro seu filho te ajudar". Ao 
lado dessa mensagem, uma sorridente criança, aparentando cinco ou seis anos, segura o cartaz com o nome da marca e seu slogan: "Red Balloon, inglês a partir dos 3 anos.” Novamente, não há no anúncio nenhuma mensagem explicitamente persuasiva a pais e mães leitores que os inste a matricular suas crianças nesse curso de idiomas. A tentativa de convencimento opera, sim, sob uma aparentemente inocente sugestão: se você, pai ou mãe que está lendo a capa da Folha de hoje, entendeu muito pouco do que está escrito nessa página, pergunte a seu filho se ele não pode te dar uma ajuda; é possível que ele saiba falar mais inglês do que você. De uma maneira muito sutil, o anúncio trabalha com uma imagem já estabelecida de seu coenunciador e modaliza seu discurso de acordo com uma reação mais ou menos previsível na outra ponta, o que nos faz relembrar o conceito de ethos pré-discursivo. Assim sendo, o enunciador da peça publicitária presume que o leitor de um jornal como a Folha de S. Paulo, naquela circunstância específica em que se depara com o anúncio, pode ser um pai ou uma mãe que não tem muito contato diário com o inglês. Mas seu filho menor, que vive conectado às tecnologias modernas e tem uma facilidade muito maior de lidar com o novo, se vê diante de termos em inglês a todo momento.

Portanto, se a situação entre pai/mãe e filho é esta (o anúncio deixa em aberto esse cenário ao inserir a interrogação no enunciado “Não tá entendendo nada?”, pois há de se levar em conta os pais e leitores da Folha fluentes na língua estrangeira), o mais prático mesmo deve ser perguntar à criança. Se ele já estuda da Red Balloon, vai poder ajudá-lo, pois é isso o que sugere o anúncio; se ele não é aluno do curso, talvez não consiga te ajudar e aquela página continuará não significando nada. É um jogo metafórico em que a capa em inglês representa uma porta para o sucesso: se você não tem os meios para decodificar a mensagem ali exposta, não tem as chaves que poderão abri-la. Seu filho ainda terá muito tempo para aprender como passar pela porta; para tanto, coloque-o na Red Balloon.

Outros comentários: o objeto desta pesquisa são os diários gratuitos modernos, mas este anúncio na Folha de S. Paulo nos traz muitos aspectos interessantes em relação à percepção do público sobre o espaço ocupado por cada tipo de veículo e o que cada um pode fazer diante do seu ethos. Os recursos de atração do leitor utilizados pela peça publicitária do Yázigi pouco diferem do que vimos agora no anúncio da Red Balloon. É possível, aliás, que um leitor se sinta mais incomodado com a falta de enunciados textuais do que com enunciados no idioma inglês. A quebra de expectativa é maior, se considerarmos que no mundo existem jornais escritos em inglês, mas não há nenhum cuja capa abdique completamente de texto - exceto em situações muito particulares e editorialmente intencionais. No entanto, o anúncio do Yázigi não causou nenhuma insatisfação entre os que 
leram a edição do Metro naquele dia nem em outros fóruns de comunicação. O mesmo não se pode afirmar sobre a peça da Red Balloon. Na internet, diversos sites e blogs da área de publicidade comentaram a “ousadia” da agência Ogilvy \& Mather, que criou o anúncio. A maioria apenas descrevia a estratégia de deixar os textos em inglês, sem opinar sobre a validade da ação. Mas não encontramos nenhum meio dentro da publicidade que criticasse o anúncio. Afinal, este parece ter cumprido sua missão de chamar a atenção do leitor pelo novo, pelo inusitado.

Nos meios jornalísticos, porém, a reação foi bastante diferente. A reprovação foi unânime, mas muito mais direcionada à decisão da Folha de aceitar ceder sua capa - ainda que tenha sido uma sobrecapa falsa - para uma intervenção publicitária de tal dimensão. Dentre as várias críticas registradas, optamos por selecionar uma e reproduzi-la na íntegra por sua representatividade.

Front page (em inglês), la une (francês), primera plana (espanhol), primeira ou capa (português) designam o espaço mais nobre de um jornal. Proscênio, altar, janela, fisionomia, marca de identidade, mesmo na imprensa popular a primeira página sempre foi envolvida por uma aura de respeitabilidade.Neste reino da avacalhação, na última década as primeiras páginas começaram a ser sistematicamente desmoralizadas num conluio entre agências de publicidade desejosas de exibir sua pseudo-ousadia e departamentos comerciais interessados apenas em atender as metas de faturamento e ganhar o seu bônus.

O vale-tudo começou paradoxalmente na chamada grande imprensa reunida sob a égide e as benções da Associação Nacional de Jornais (ANJ). A prostituição do lugar de honra dos jornais foi primeiro experimentada na Paulicéia Desvairada, depois se estendeu ao resto do país. Inicialmente sob a forma de sobrecapas publicitárias ocupando metade das primeiras páginas e, depois, diante da ausência de protestos, a ocupação passou a ser integral.

Ajuda extraordinária

Fundadores de jornais-monumentos certamente reviravam-se em suas veneráveis tumbas quando debaixo de cabeçalhos que ajudaram a glorificar penduravam-se ofertas de liquidificadores, linguiças e nabos. Virgindade perdida, na fase seguinte foi fácil aos fabulosos criativos das agências sugerir brincadeiras com capas ditas "promocionais” ou disfarçadas de "informes publicitários”, conspurcando não apenas o veículo, mas a sua relação com os leitores.

Na segunda-feira (20/6), a Folha de S. Paulo vendeu-se a uma franquia de cursos de inglês chamada Red Baloon. Inventou uma capa inteiramente escrita em inglês com o mesmo design e teor da capa verdadeira. Genial?

Estúpido! Inglês macarrônico, capenga, burlesco, traduzido ao pé da letra, incompreensível para anglo-saxões porque os pobres tradutores foram obrigados a manter o tamanho dos títulos e a própria organização das frases em português.

Com a inestimável ajuda da Red Baloon, a Folha criou na última segundafeira do outono uma caricatura idiomática chamada Portinglês e uma nova retranca - a "Folha-shit". ${ }^{18}$

\footnotetext{
${ }^{18}$ DINES, Alberto. “'Folha-shit’, a invenção genial”. Observatório da Imprensa, ed. 647, 21/06/2011
} 
Antes que se faça qualquer observação sobre as opiniões contidas no texto acima, é importante situar seu autor e o público para o qual escreve. Alberto Dines é um respeitado e veterano jornalista. Aos 79 anos, já teve cargos de chefia nas principais redações do Brasil, mas há algum tempo "rompeu” com a grande imprensa e se tornou um crítico ácido do modo de produção jornalística desses periódicos. É o criador do Observatório da Imprensa, considerado o primeiro veículo de acompanhamento de conteúdos midiáticos no Brasil. Dines tende a defender ideias "puristas” sobre o discurso jornalístico, entre as quais o maior afastamento possível entre o conteúdo noticioso e os anúncios publicitários. Ele confirma a expectativa criada por seu ethos pré-discursivo ao definir a inserção da publicidade nas capas dos periódicos como uma "prostituição do lugar de honra dos jornais”. Afirma também que o surgimento das capas “ditas ‘promocionais’ ou disfarçadas de ‘informes publicitários””, como é o caso da peça da Red Balloon, traz danos de imagem não só ao veículo, mas também à relação com os leitores. A título apenas de curiosidade, sem nenhuma pretensão científica, consultamos algumas pessoas sem relação profissional com o meio jornalístico sobre o que acharam do anúncio. Muitos consideraram “curioso” ou "inusitado”, mas se disseram “surpresos” com o fato de ter saído na capa da Folha. Mesmo sem conseguirem externar o porquê da surpresa, não é difícil entender: o ethos que um jornal como a Folha carrega consigo se choca com a ideia de tamanho imbricamento com a linguagem publicitária, e desfazer essa noção é um processo complexo.

Concordar ou não com Dines sobre a "gravidade” de um anúncio como este estampar a capa de um quality paper não é o que se propõe esta pesquisa. Mas um aspecto técnico levantado pelo texto merece nossa análise: as inadequações dos termos em inglês utilizados na tradução. Uma pessoa pouco habituada a ler sites jornalísticos em inglês ou que tem um domínio limitado da língua pode talvez nem perceber, mas há erros evidentes de impropriedade vocabular nas chamadas da capa. Alguns exemplos: na manchete "Tax benefit is not controlled, said TCU”, o correto seria usar o verbo “says” (diz), no presente. Numa das chamadas menores do canto inferior direito, está escrito: "Social media rumours defies market affecting investiments”. Toda a construção em si soaria mal para um falante do inglês, pelo uso de termos que não encaixam direito entre si; mas o que salta aos olhos são dois erros gramaticais. Primeiro, o uso do verbo “defies” (desafia), na terceira pessoa do singular, precedido de um substantivo no plural, "rumours" (rumores). O certo seria "defy" - certo apenas gramaticalmente, mas inadequado dentro do falar prático do inglês. Em segundo lugar, há um erro de grafia: não é “investiments”, mas sim “investments”. Dines levanta a provável hipótese de que os tradutores foram obrigados a respeitar o tamanho das chamadas e a 
organização das frases em português. Como a capa só lhes deve ter chegado quase em cima do fechamento do jornal, devem ter tido um tempo muito curto para trabalhar na tradução. Mesmo assim, não se justifica a quantidade de erros existente em um material não tão extenso. Se um dos objetivos da publicidade é usar a enunciação para conferir a si mesma aquilo que ela evoca (MAINGUENEAU, 2008), logo o anúncio da Red Balloon falha em seu intuito. A ideia sugerida pela peça é a de que esse curso de idiomas é confiável para os pais colocarem seus filhos lá. Mas que credibilidade traz a mensagem publicitária se ela própria se contradiz? Quem vai confiar em uma escola de inglês cuja publicidade traz, justamente, erros de inglês? Eis um caso em que o conteúdo da mensagem pode prejudicar sobremaneira sua forma criativa. 
Figura 5.12 - Reprodução da sobrecapa da Folha de S. Paulo de 20/06/2011

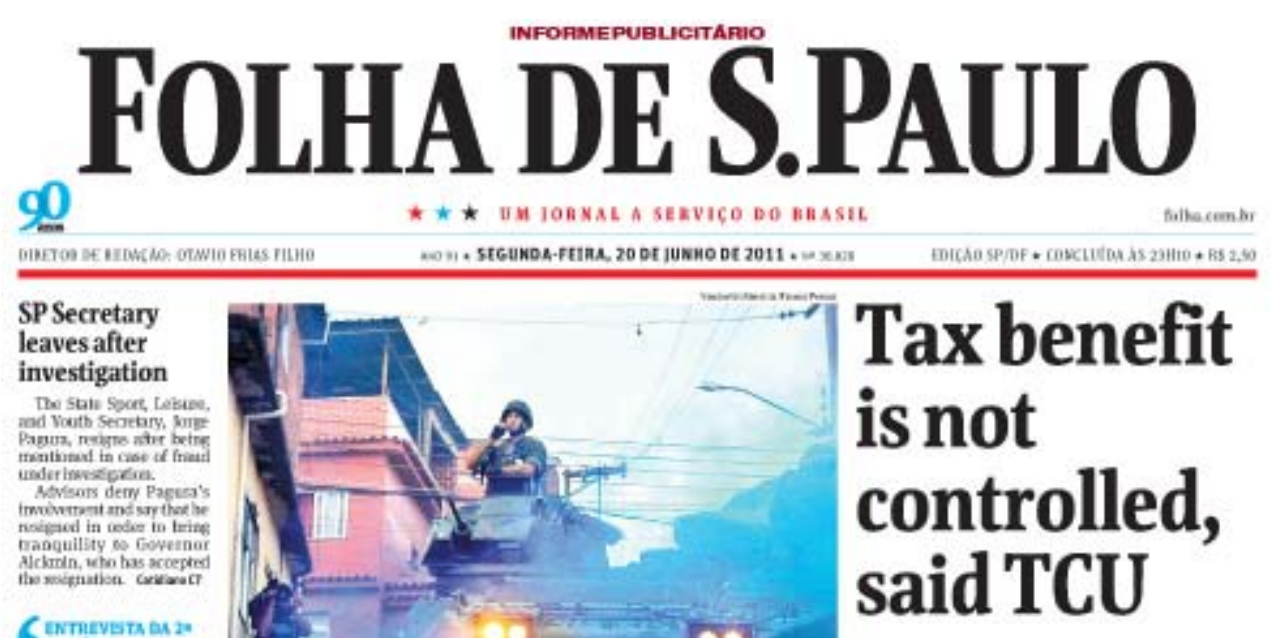

Solning

'Only Jesus Christ saves the World

Cup in Brazil'

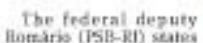

that bast wonit te ahk th

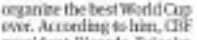

miskisat Hickando Telistia

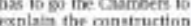

ispienses. Ais

Ehe Xitw ilork Eime:

Dissidents get the

USA aid to use the

Internet. $\cdots+1$

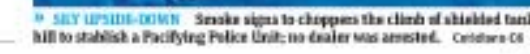

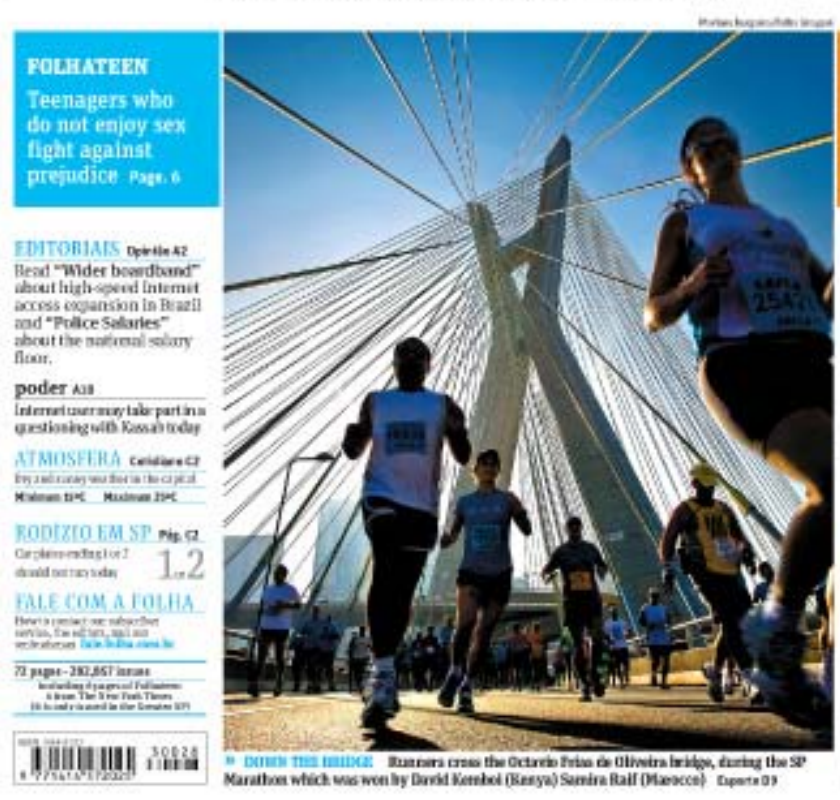

Exemption reaches RS144 bi in 2010; National Treasury Deptdoesn't comment Inapexisus fran the The lack of caniml on

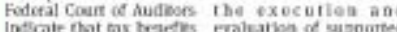
obred tor the gownament provares accoediag to

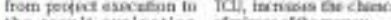
the result eval uation comisusefofthemsacy. cutatid.

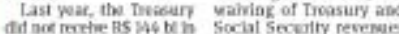
dit nas rere

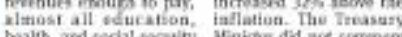

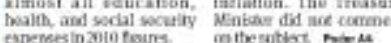

Health Insurance plans have a deadline to assist patients

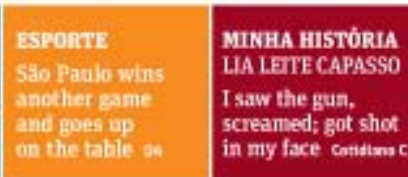

\section{Greek PM appeals to the government}

\begin{tabular}{|c|c|}
\hline 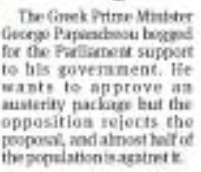 & 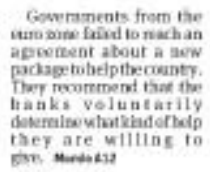 \\
\hline $\begin{array}{l}\text { motucassoraurs } \\
\text { rail shoud have } \\
\text { plare in the UN } \\
\text { ceurity Courcil }\end{array}$ & $\begin{array}{l}\text { Social Medla } \\
\text { rumours defies } \\
\text { market affecting } \\
\text { investiments }\end{array}$ \\
\hline 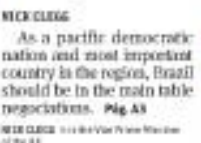 & $\begin{array}{l}\text { Eustavo cewass } \\
\text { Due to highinterest, } \\
\text { consortium is the } \\
\text { way to buy cars on }\end{array}$ \\
\hline
\end{tabular}

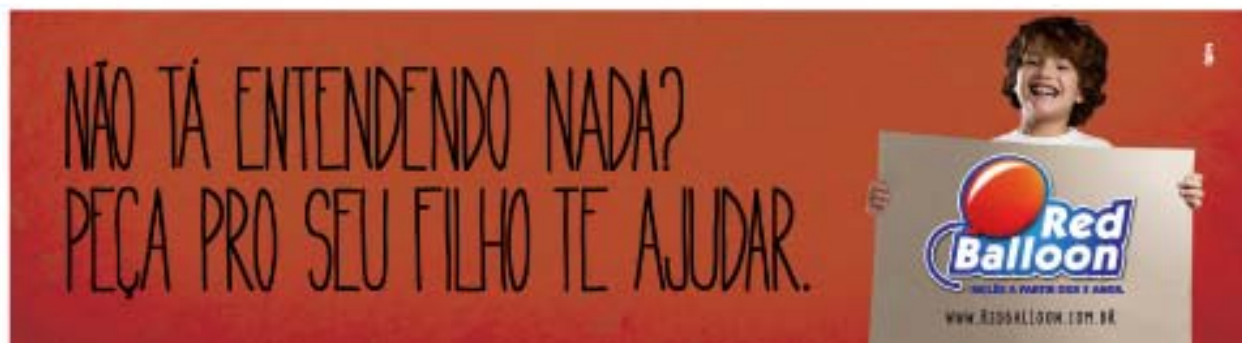


Figura 5.13 - Reprodução da capa da Folha de S. Paulo de 20/06/2011
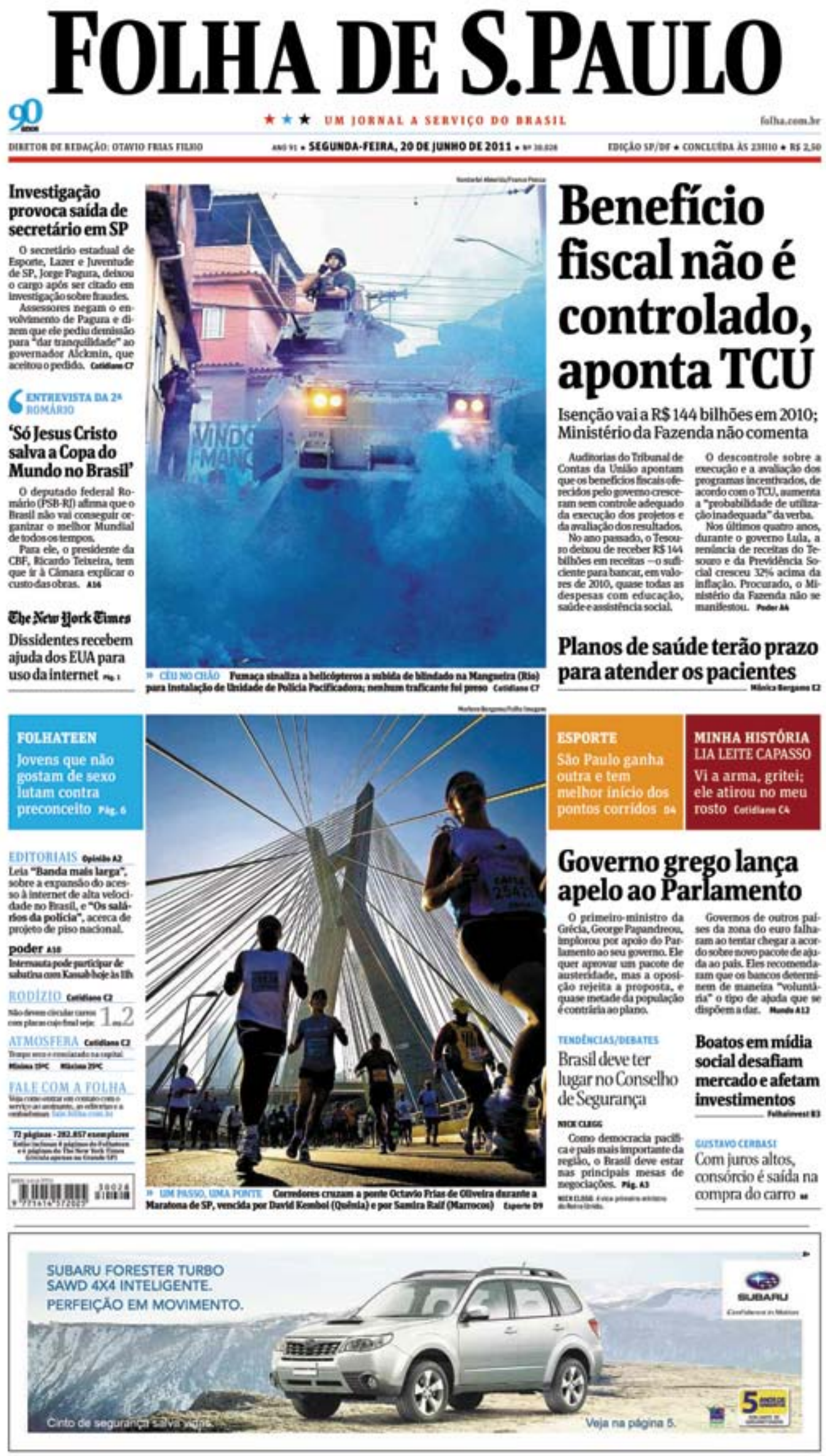


\section{Grupo 2}

\section{Chamadas de capa 1 e 2 - Segunda temporada da série Glee no Brasil}

Data: 9/2/2011

\section{Veículos em que foram publicadas: Destak e Metro}

Formato: recorte de fotografia no terço superior e superior direito da capa

Cena englobante: enunciado jornalístico

Cena genérica: chamada de capa sobre a estreia, no Brasil, da segunda temporada da série de TV Glee

Cenografia: na capa do Destak, há uma foto recortada de dois personagens da série, com um sorriso de empolgação, jogam o que aparenta ser um copo de tinta na "direção do leitor. Ao lado, há a chamada “Glee está de volta, e a carrasca também”, seguida do texto “Jane Lynch retorna como a temida treinadora na segunda temporada”. No Metro, há o recorte de foto de sete personagens, incluindo os que aparecem na capa do Destak. Nota-se que se trata da mesma foto de divulgação da série, mas o Metro optou por mostrar mais gente do elenco. Do lado esquerdo, o enunciado é feito com letras maiúsculas e em destaque de negrito: “Finalmente - Segunda (e esperada) temporada de Glee estreia no Brasil”

Aspectos polifônicos e interdiscursividade: até este ponto da pesquisa, restringimo-nos a analisar elementos do discurso jornalístico imbricados em um enunciado vinculado ao discurso publicitário. A partir de agora, o objetivo é inverso: passamos a selecionar o que há de linguagem da publicidade em um tradicional gênero discursivo jornalístico: a chamada de capa. Trata-se de um gênero cujas normas internas implicam a referência a um tema considerado relevante dentro do jornal (tanto que mereceu aparecer na capa) por meio de um formato sintético, porém atraente ao leitor. Pode ou não vir acompanhado de fotos. Um espaço nobre para uma chamada de capa (sem contar manchete e submanchete, que constituem outro gênero discursivo com suas regras específicas) é o canto superior direito. É exatamente esse perfil de chamada que nos disporemos a analisar. No caso deste primeiro exemplo, tanto o Metro quanto o Destak utilizam uma imagem de divulgação da série (o que fica claro pelo crédito da foto na página do Destak). Trata-se da foto-símbolo da segunda temporada, tal como aparece na Fox, canal em que o programa é transmitido. Podemos falar, aí, em uma heterogeneidade marcada, em que a intertextualidade com a série se dá pela citação. Quanto aos enunciados textuais, o Destak opta por uma abordagem mais próxima do discurso jornalístico; ao mesmo tempo que informa sobre a "volta” de Glee, complementa com a informação de que a personagem da atriz Jane Lynch retorna como "a temida treinadora”. A outra mensagem é a legenda da foto, que explica quem são aquelas pessoas. 
Em relação à chamada do Metro, há um forte apelo emotivo no enunciado textual que o aproxima mais da linguagem publicitária, a começar pela palavra “FINALMENTE” em caixa alta e negrito, para chamar mais a atenção. Na sequência, diz que a segunda temporada de Glee era “esperada”. Mas esperada por quem? Entra aí a questão do direcionamento muito claro a um segmento do público-leitor. O Metro não está dialogando com qualquer pessoa que eventualmente venha a ler o jornal, mas sim àqueles fãs de Glee. Em tempo: Glee (alegria, prazer, em uma tradução livre) é um seriado musical americano que narra a experiência de um grupo de jovens participantes de um coral. Fez sucesso imediato nos Estados Unidos e chegou ao Brasil pela TV a cabo, onde teve uma repercussão não menos exitosa. O público que o assiste é, em geral, jovem, urbano e consumidor de novas tendências, sejam elas quais forem. Não à toa, é justamente o público-alvo visado pelos gratuitos modernos. Tal como a publicidade sempre busca dirigir-se a um grupo específico e compartilha com ele seus valores, assim o fazem Metro e Destak. Concedem um espaço generoso de sua capa nesse dia para informar a seus leitores-telespectadores de Glee que a segunda temporada vai começar. Se você é mais velho e não tem a mínima ideia do que seja Glee, paciência. Nenhum dos dois gratuitos parece muito preocupado em explicar isso a leigos. O Metro aprofunda esse diálogo com os mecanismos publicitários; o enunciado textual nos leva a crer nisso, como vimos. Mas também há um detalhe que diferencia o Metro do Destak nesse exemplo: se neste há uma legenda para explicar a foto (e a legenda é outro consagrado gênero discursivo marcadamente jornalístico), naquele a legenda inexiste. Talvez porque, se o jornal está tratando com fãs do seriado, qual a necessidade de explicar quem é quem ali? Todo mundo já sabe. No cartaz da segunda temporada do qual foi retirada essa foto, tampouco há legendas. O que externamente aparenta ser uma chamada de capa como a de qualquer jornal é, no fim das contas, uma semipublicidade da série Glee. 
Figura 5.14 - Reprodução da capa do Destak de 09/02/2011

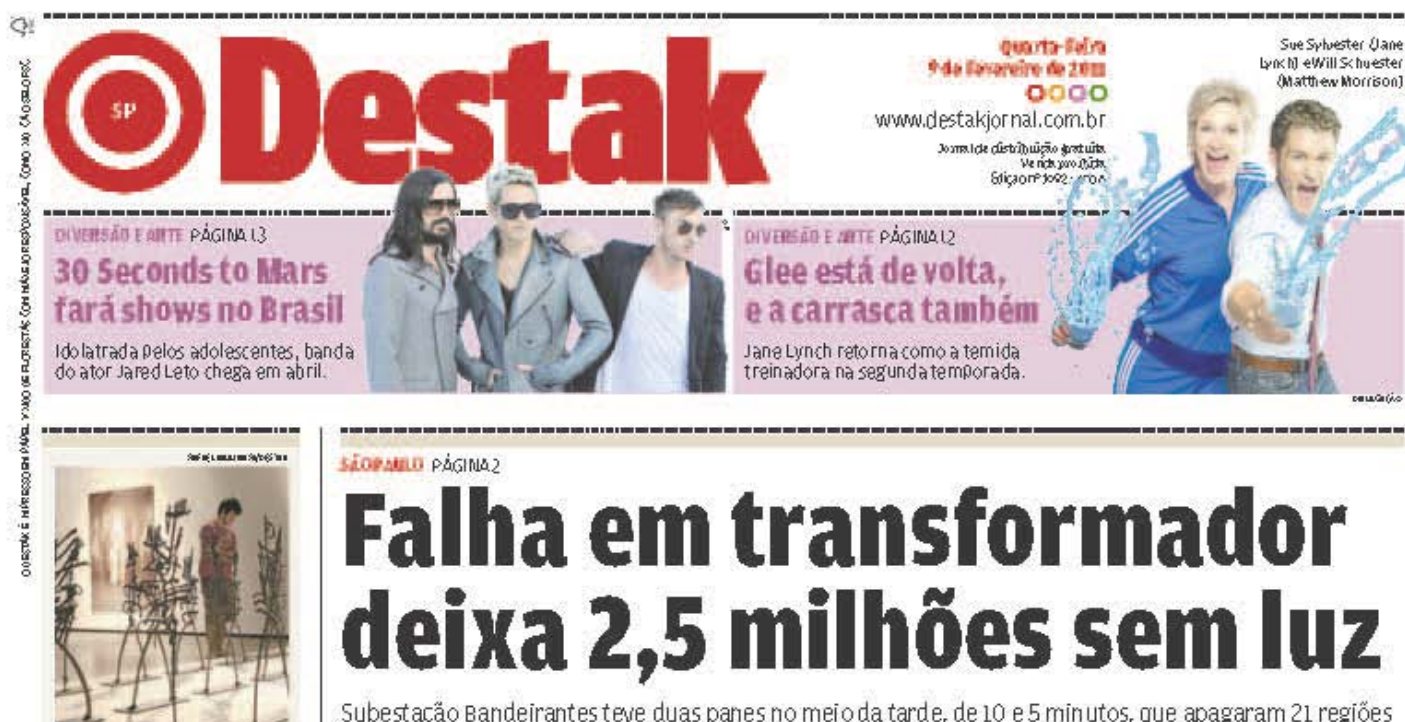

Subestação Bandeirantes teve duas pares no meio da tarde, de 10 e 5 minutos, que apagaram 21 regiôes da cidade; corte parou bombas da Sabesp e abastecimento de água no horumbi e em outros sete bairros

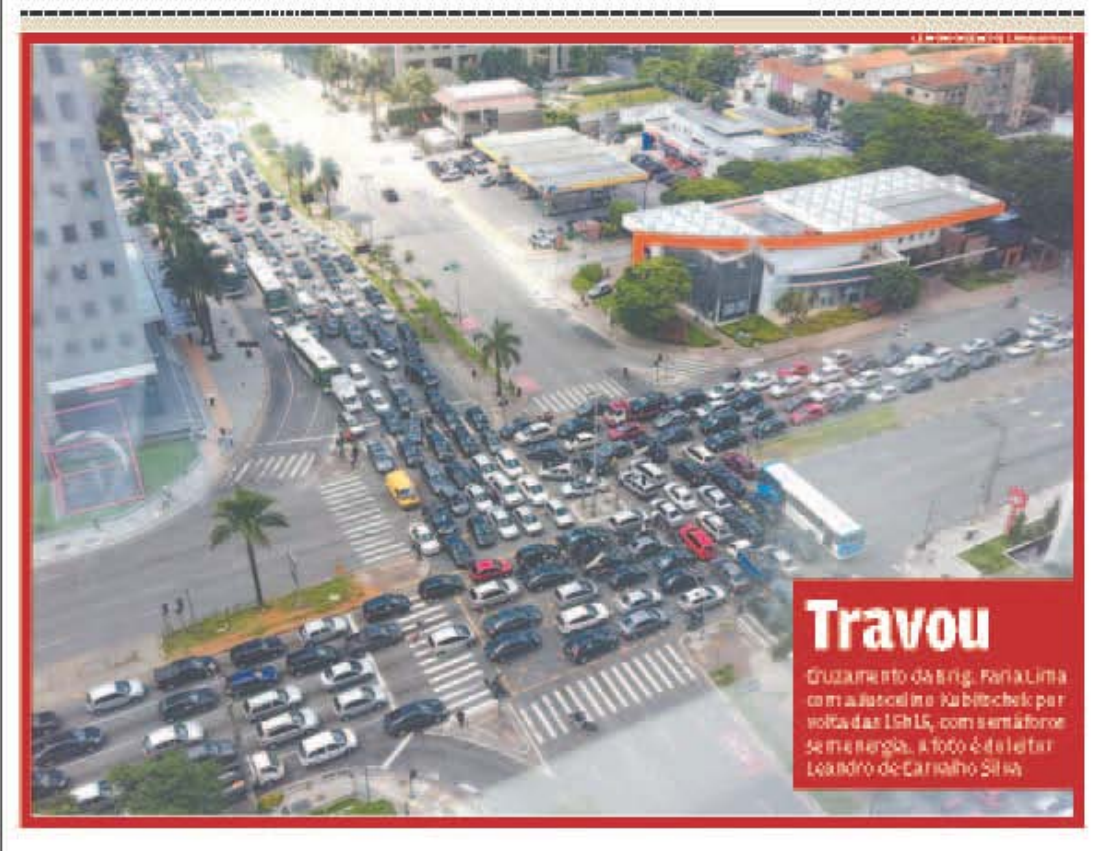

Secretário saulo de Castroé feitorefém em assal to em casa 
Figura 5.15 - Reprodução da capa do Metro de 09/02/2011

BRASP_2011-02-09_1. qxp : ERAZIL 2/8/11 10:04 pM Page 1

FINALMENTE SEGUNDA (E ESPERADA) TEMPORADA DE 'GLEE' ESTREIA NO BRASIL ${ }_{\text {ins } 147}$
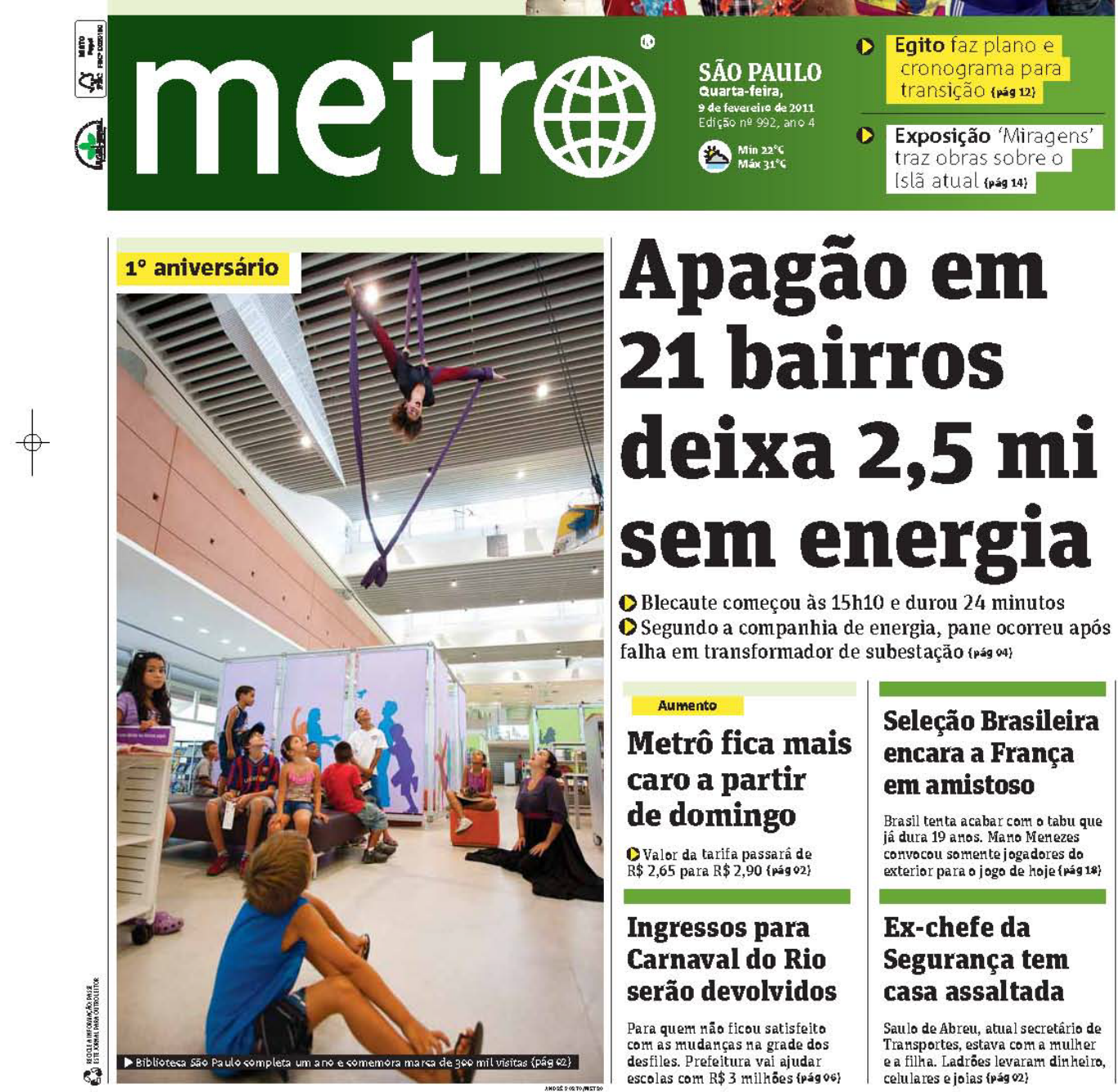

Apagão em 21 bairros deixa 2,5 mi sem energia

O Blecaute começou às $15 \mathrm{~h} 10$ e durou 24 minutos D Segundo a companhia de energia, pane ocorreu após falha em transformador de subestação \{pág 04\}

\begin{tabular}{|c|c|}
\hline $\begin{array}{l}\text { Aumento } \\
\text { Metrô fica mais } \\
\text { caro a partir } \\
\text { de domingo } \\
\text { Ovalor da tarifa passara de } \\
\text { R } \$ 2,65 \text { para } \$ 2,90 \text { \{́ág } 02\}\end{array}$ & $\begin{array}{l}\text { Seleção Brasileira } \\
\text { encara a França } \\
\text { em amistoso } \\
\text { Brasil tenta acabar com o tabu que } \\
\text { jâ dura } 19 \text { aros. Maro Merezes } \\
\text { convocou somente jogadores do } \\
\text { exterior para o jogo de hoje \{rág 18? }\end{array}$ \\
\hline $\begin{array}{l}\text { Ingressos para } \\
\text { Carnaval do Rio } \\
\text { serão devolvidos }\end{array}$ & $\begin{array}{l}\text { Ex-chefe da } \\
\text { Segurança tem } \\
\text { casa assaltada }\end{array}$ \\
\hline $\begin{array}{l}\text { Para quem mão ficou satisfeito } \\
\text { com as mudanças na grade dos } \\
\text { desfiles. Prefeitura vai ajudar } \\
\text { escolas com } \mathrm{R} \$ 3 \text { milhôes \{́ág o6\} }\end{array}$ & $\begin{array}{l}\text { Saulo de Abreu, atual secretấrio de } \\
\text { Transportes, estava comm a mulher } \\
\text { ea fillha. Ladróes levaramt dirhheiro, } \\
\text { celulares e joias \{́pág } 02\}\end{array}$ \\
\hline
\end{tabular}




\section{Chamada de capa 3 - Nova versão do jogo Mortal Kombat}

Data: $10 / 3 / 2011$

Veículo em que foi publicado: Metro

Formato: recorte de fotografia no terço superior da página

Cena englobante: enunciado jornalístico

Cena genérica: chamada de capa sobre o lançamento de uma nova versão do jogo Mortal Kombat

Cenografia: reprodução de uma cena de ação do jogo, em que um lutador tenta atingir o outro com uma corrente, e este se defende. No espaço entre os dois, o enunciado sobre a apresentação da nova versão

Aspectos polifônicos e interdiscursividade: quando se propõe a dialogar com um público-alvo específico, a publicidade frequentemente recorre a símbolos que representam esse público para facilitar a captura de sua atenção - não é nosso papel aqui estendermo-nos sobre essa discussão, mas consideramos a noção peirceana de símbolo, a saber, um signo que não apresenta similaridade com seu objeto dinâmico (a coisa representada), mas o representa por causa de uma convenção sociocultural (SANTAELLA, 2000). Nesta chamada de capa do Metro, nota-se que há uma estratégia parecida. O jogo de luta Mortal Kombat, lançado em 1992, tornou-se rapidamente uma febre entre crianças e adolescentes à época de uma segunda geração de videogames, encabeçada pelo console Mega Drive. O sucesso foi tão grande que o jogo ganhou versão em quadrinhos, depois série de TV e até filme. As crianças do início dos anos 90 foram crescendo, mas o vínculo afetivo com o Mortal Kombat não se desfez. A nova versão à qual o Metro faz referência é a 9, e o jogo agora é feito para videogames modernos, o XBOX 360 e o Playstation 3, presentes nas casas tanto das crianças de hoje como dos adultos que jogaram o primeiro Mortal Kombat. Não nos parece exagero dizer que este jogo representa uma geração de crianças urbanas que cresceram cercadas de novas tecnologias e hoje são adultos que não se desgarraram do hábito do videogame. A chamada de capa do Metro, portanto, se destina a uma parcela muito específica do público-leitor, por definição homens de classe média-alta, habitantes dos grandes centros urbanos, que hoje beiram os 30 anos. Chama a atenção também o tamanho do título da chamada, que funciona quase como uma submanchete dentro da página. A reprodução de uma cena do jogo contribui para atrair o leitor ao fazê-lo relembrar da época em que ficava horas à frente da TV lutando com os personagens de Mortal Kombat. 
Figura 5.16 - Reprodução da capa do Metro de 10/03/2011

BRASP_2011-03-10_1. q9P: ERAZIL 3/10/11 12:08 AM Page 1

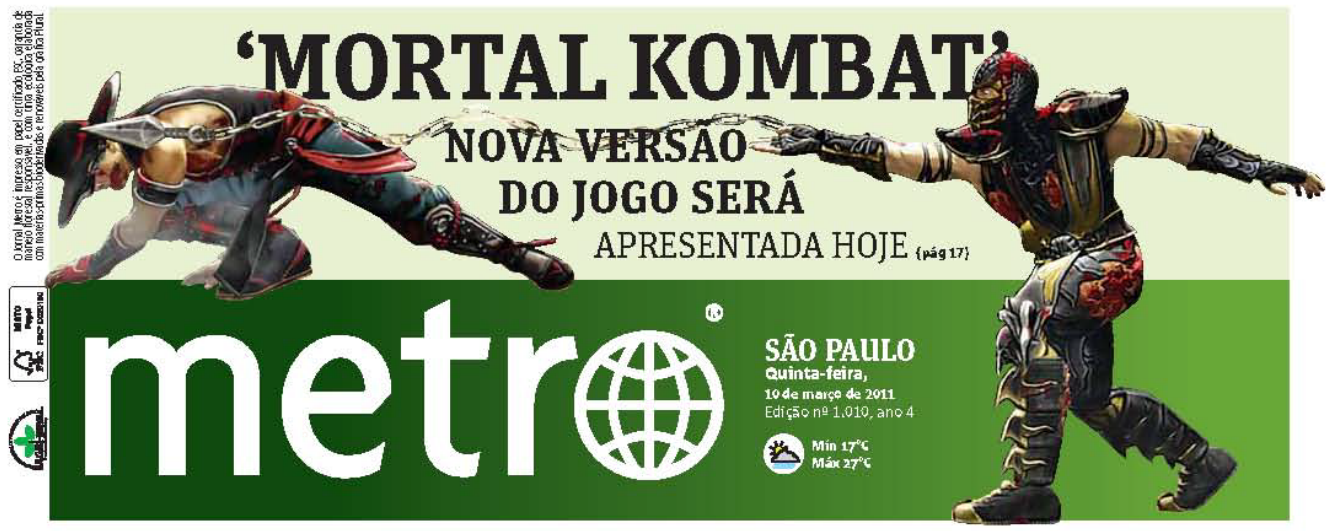

Recall constará no documento do carro

O Com a medida, compradores de carros usados poderão saber se o antigo proprietârio atendeu aos chamados das montadoras para reparos 0 Portaria do Ministério da Justiça entra em vigor no próximo dia 17 \{pág 13\}
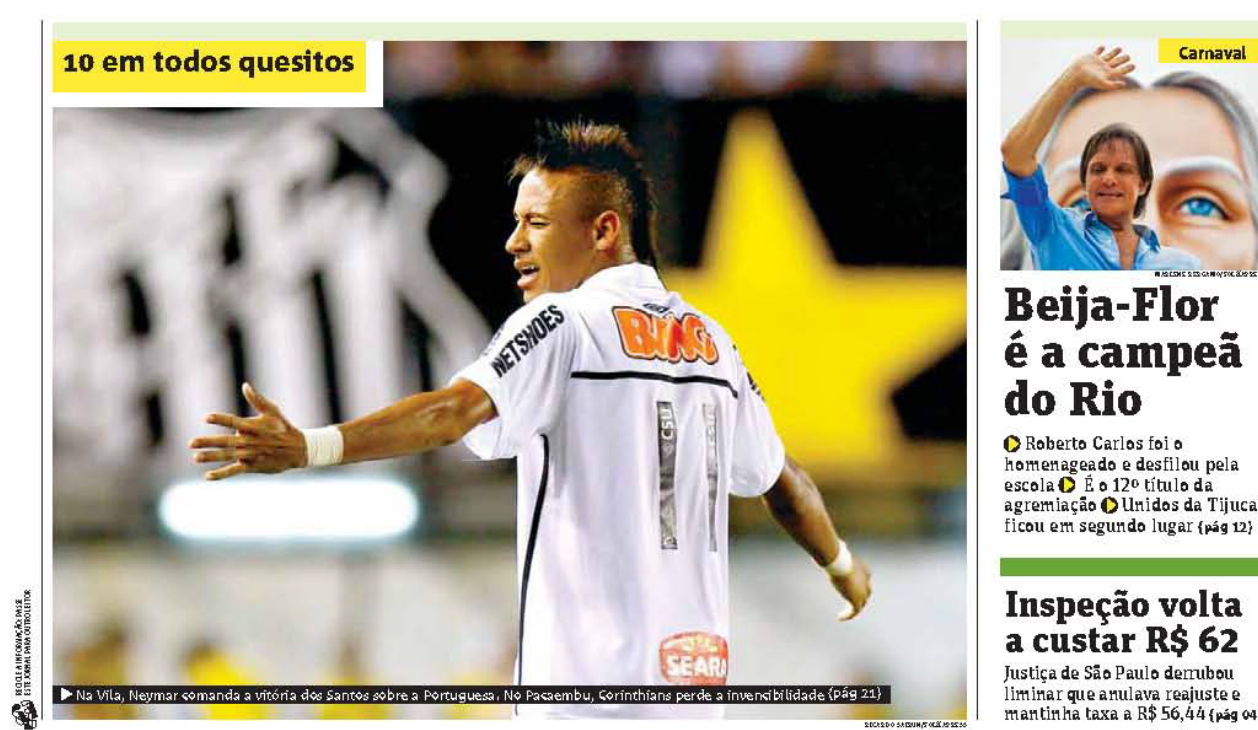

Beija-Flor é a campeã do Rio

Roberto Carlos foi o homenageado e desfilou pel escola 1 E o $12^{\circ}$ títula da acrertiaça Duntas da Tijuca

Inspeção volta a custar $R \$ 62$

ustiça de São Paulo demubou liminar que anulava reajuste $e$ mantinha taxa a $R \$ 56,44$ \{́ág ou 


\section{Chamadas de capa 4, 5 e 6 - Primeira exibição do filme Rio no Brasil}

Data: 22/3/2011

Veículos em que foram publicadas: Destak, Metro e Folha de S. Paulo

Formato: foto-legenda no terço central da página (Folha), retângulo no canto superior esquerdo (Destak), recorte de foto e texto no canto superior direito e central (Metro)

Cena englobante: enunciado jornalístico

Cena genérica: chamada de capa sobre a pré-estreia mundial da animação Rio

Cenografia: na Folha, uma foto retrata a sorridente atriz de Hollywood Anne Hathaway ao fundo de uma representação de uma das araras que são personagens de Rio; abaixo, uma legenda explica a imagem. No Destak, há uma reprodução de uma cena do filme, acompanhada do título da chamada "Hollywood é ali no Rio de Janeiro”. Por fim, no Metro, há um recorte estilizado de cinco personagens da animação, acompanhado de uma chamada com tipologia maior: "Rio” - Nova animação tem $1^{\text {a }}$ exibição no Brasil.

Aspectos polifônicos e interdiscursividade: esta pesquisa visa, entre outros aspectos, a demonstrar como elementos da linguagem publicitária estão inseridos de forma mais incisiva no discurso jornalístico dos gratuitos em comparação com um quality paper pago, no caso a Folha de S. Paulo. A ocasião da pré-estreia mundial da animação digital Rio, realizada em março no Rio de Janeiro, nos parece um exemplo muito ilustrativo dessa diferenciação entre gratuitos e pagos. Primeiro, faz-se necessária uma contextualização factual: Rio é uma animação da 20th Century Fox, dirigida pelo brasileiro Carlos Saldanha, também responsável por outros sucessos desse filão do cinema, como A Era do Gelo 2. O filme narra a história de uma arara-azul macho que é levada dos Estados Unidos para o Rio de Janeiro para se acasalar com uma fêmea da mesma espécie. No elenco de dubladores há atores famosos de Hollywood, como Anne Hathaway e Jesse Eisenberg. Todos vieram ao Rio para a primeira exibição mundial. Logo, tratava-se de um fato jornalístico de relevo para a mídia brasileira. O que nos interessa é avaliar, pela análise das chamadas de capa, como cada veículo abordou o episódio. A começar pela Folha: o jornal optou por publicar uma foto de Anne Hathaway em segundo plano, atrás de um boneco das araras personagens do filme. A legenda da foto é essencialmente informativa: "Voz Carioca - Dubladora de personagem da animação "Rio", a atriz Anne Hathaway participa de sessão de fotos para pré-estreia mundial na cidade; o diretor brasileiro Carlos Saldanha refutou comparação com filme da Disney”. No todo da página, a foto de Anne é um elemento ilustrativo importante, mas ocupa uma posição marcadamente secundária em relação à imagem da manchete por estar no terço central, encaminhando-se para o inferior. O diálogo com a linguagem publicitária é praticamente nulo. Vale notar, 
ainda, que o jornal noticiou o fato um dia depois (23 de março), como um acontecimento jornalístico comum já ocorrido. Os gratuitos deram amplo espaço no dia em que aconteceria a exibição, como que anunciando - no sentido publicitário - o evento. No Destak, a hierarquização do enunciado já é bastante diferente da observada na Folha. O lançamento do filme ocupa uma chamada no canto superior esquerdo, logo abaixo do logo do jornal. A reprodução de uma cena da animação chega inclusive a se sobrepor à parte do nome do veículo. É evidente uma valorização imagética voltada para o entretenimento em si. Mas o enunciado textual ainda guarda mais relação com uma linha jornalística: "Hollywood é ali no Rio de Janeiro - Astros chegam à cidade para pré-estreias da animação Rio e do quinto filme da franquia Velozes e Furiosos". Como no caso da chamada de capa da série Glee, aqui também o Destak mantém a prática de pôr legendas nas fotos, algo que reforça o caráter jornalístico da composição. Ao lado das araras-azuis e do tucano andando de asa-delta, há a seguinte informação: “Rio, animação dirigida pelo brasileiro Carlos Saldanha.” Por fim, chegamos ao Metro, o gratuito que mais nos parece se aprofundar no imbricamento dos discursos publicitário e jornalístico. Tal como no Destak, a estreia de Rio está registrada em uma chamada de capa na parte superior da página; mas, diferentemente deste, não tem que dividir espaço com outra chamada de capa de igual tamanho. Rio é, indiscutivelmente, o maior destaque nessa parte da capa. A imagem dos personagens é muito maior que a publicada pelo Destak e se trata de um recorte de um cartaz de divulgação do filme, o que reforça o vínculo com o aspecto publicitário da animação. O cartaz a que nos referimos é o reproduzido na página seguinte. Os elementos de sedução típicos do discurso publicitário estão presentes. Reparemos especificamente em um deles, que foi mantido no recorte da foto do Metro: o pequeno pássaro na cabeça da arara azul, aparentemente um canário amarelo, segura na cabeça um pandeiro verde. Há, aí, vários estereótipos do Brasil. O pandeiro remete ao samba, ritmo musical que se tornou sinônimo do país no exterior. O verde do instrumento se mescla ao amarelo da ave para ganhar as cores da bandeira brasileira. O filme funciona, na verdade, quase como uma peça publicitária que exalta as belezas naturais e a riqueza cultural do Rio de Janeiro como cartão-postal do Brasil. É o que retrata o cartaz: praia cheia, mar azul, dia ensolarado e os morros (sem favelas, é claro) ao fundo. 
Figura 5.17 - Reprodução do cartaz de divulgação da animação Rio

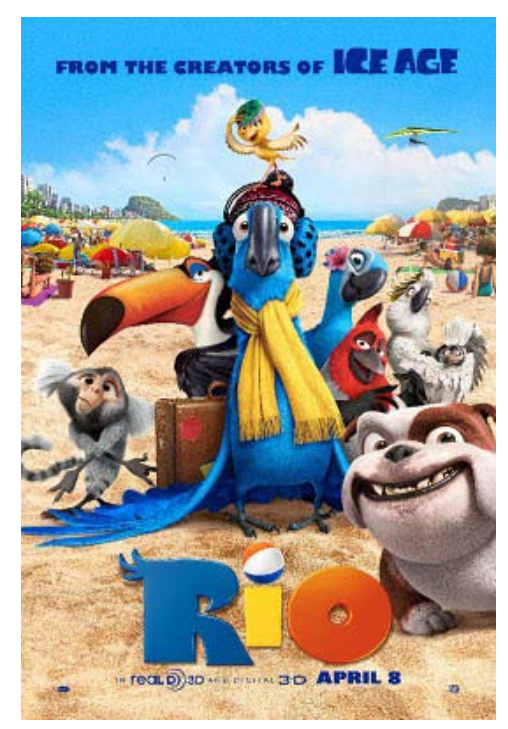

A dialogia com a publicidade segue no enunciado textual. Tal como pudemos observar na chamada de capa sobre o jogo Mortal Kombat, a tipologia utilizada e o emprego do nome do produto em destaque muito maior que o restante do texto da chamada nos remete a uma ideia de cartaz. No Metro, a pré-estreia de Rio pode ser encarada como a submanchete daquela edição. No Destak, esse fato tem uma hierarquização importante, mas não a esse nível. Na Folha, a foto chama a atenção, mas ocupa um espaço secundário no todo da capa. É importante notar que, no Metro, o enunciado não se propõe a relatar nenhum outro aspecto que não seja a pré-estreia em si: “Nova animação tem $1^{\mathrm{a}}$ exibição no Brasil”. Em sua chamada, o Destak cita o lançamento de outro filme (Velozes e Furiosos) e usa isso como “gancho” (jargão jornalístico para fatos que podem remeter a um determinado fenômeno mais amplo) para dar uma ideia da presença hollywoodiana no Rio de Janeiro. A Folha, por sua vez, menciona na chamada uma discussão sobre se o personagem principal de Rio, a arara Blu, não é uma recriação do papagaio Zé Carioca, criado pelos estúdios Disney nos anos 40. Ou seja, há uma tentativa de problematização contextual que simplesmente inexiste no enunciado do Metro. O gratuito não se reserva essa missão. Para seus leitores que gostam de diversão e entretenimento, como bem pontuou a editora Noelly Russo, o mais importante é divulgar o filme. Portanto, no grau de aproximação dialógica jornalismo-publicidade, fomos do menos intenso (Folha) para o mais intenso (Metro), passando por uma escala intermediária (Destak). Com esta análise, consideramos ter abarcado exemplos que fundamentam nossa argumentação e passaremos às considerações finais desta pesquisa. 
Figura 5.18 - Reprodução da capa da Folha de S. Paulo de 23/03/2011
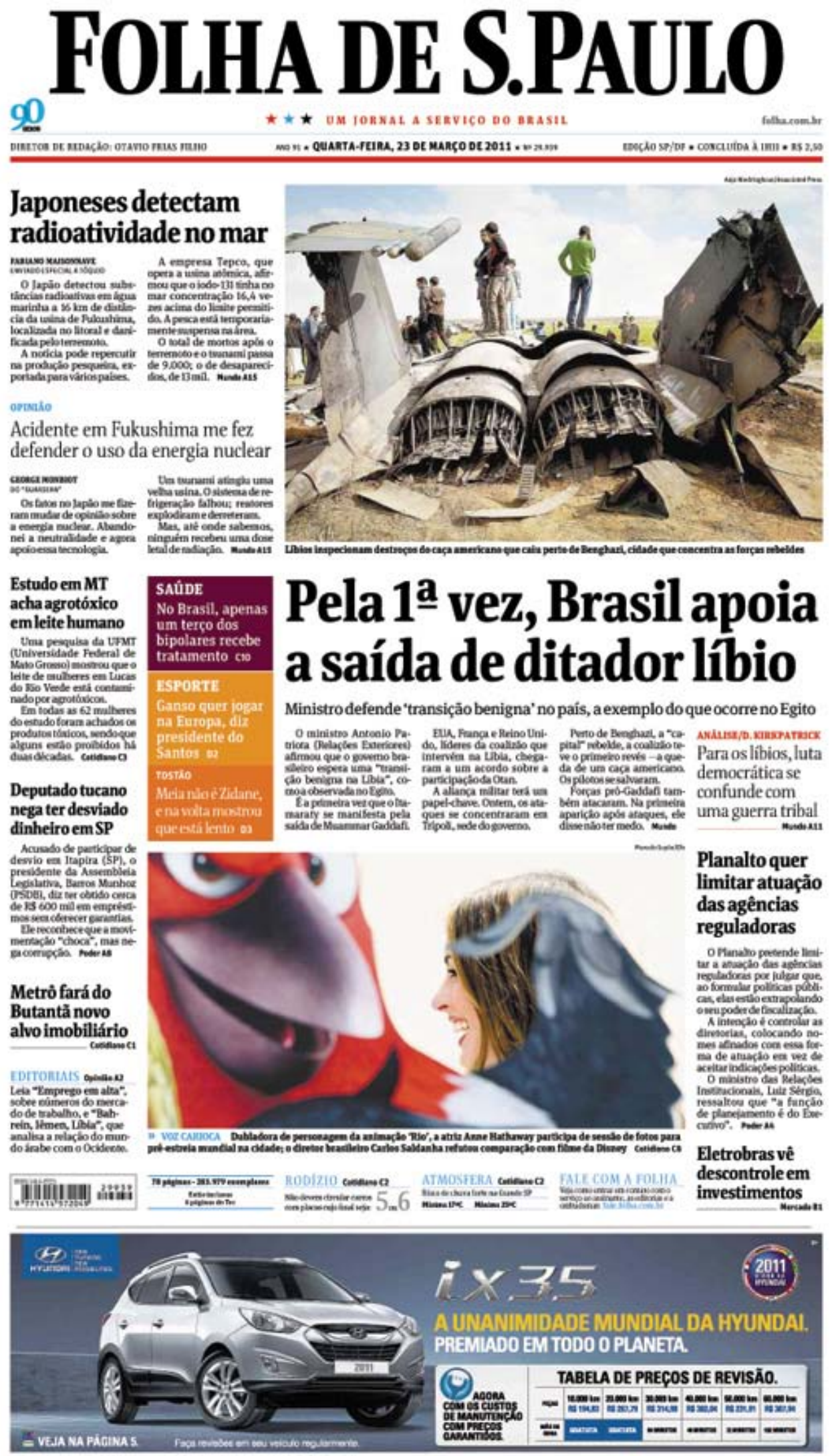
Figura 5.19 - Reprodução da capa do Destak de 22/03/2011

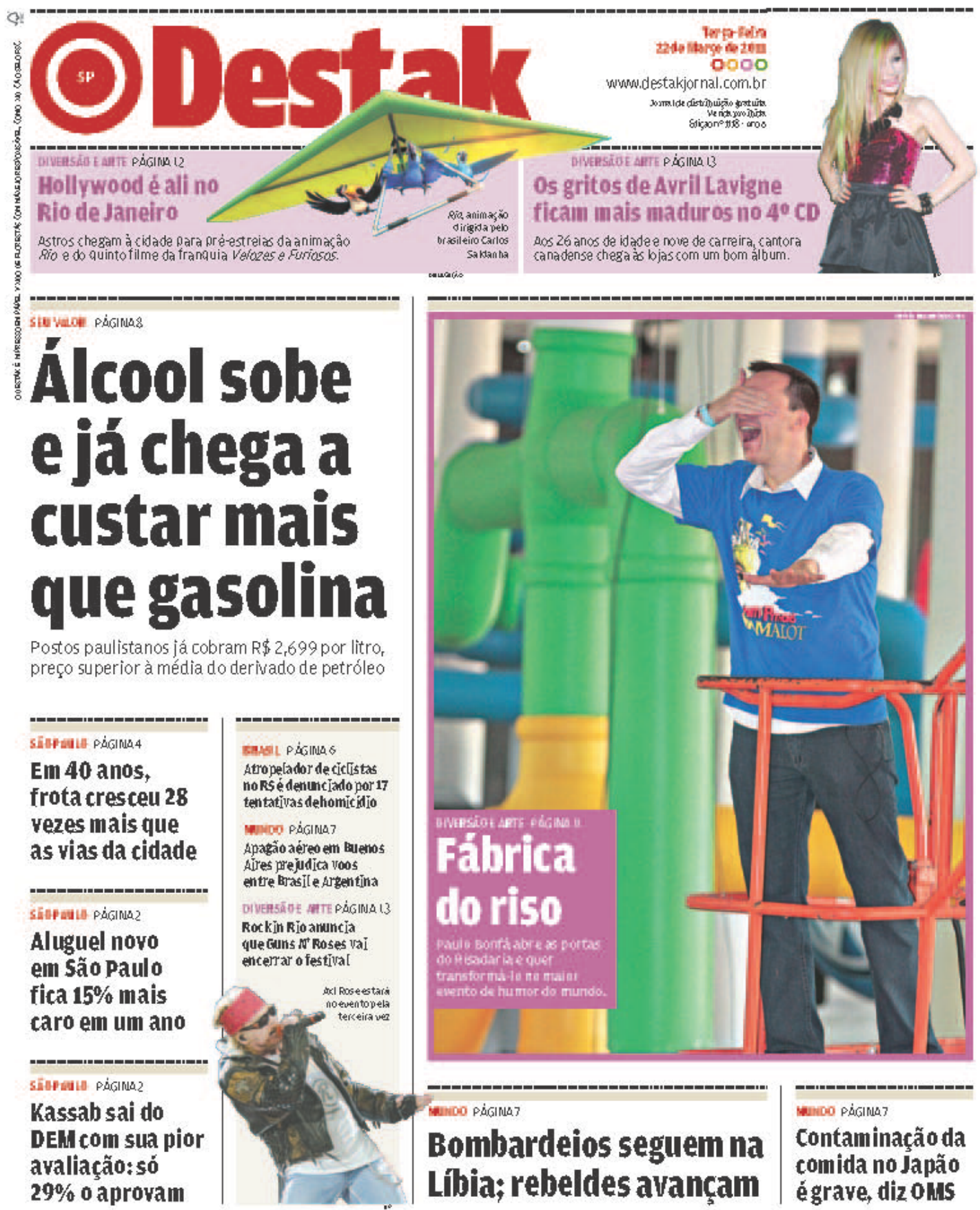


Figura 5.20 - Reprodução da capa do Metro de 22/03/2011

|BRASP_2011-03-22_1. qxp: ERAZIL 3/21/11 9:28 pM Page 1

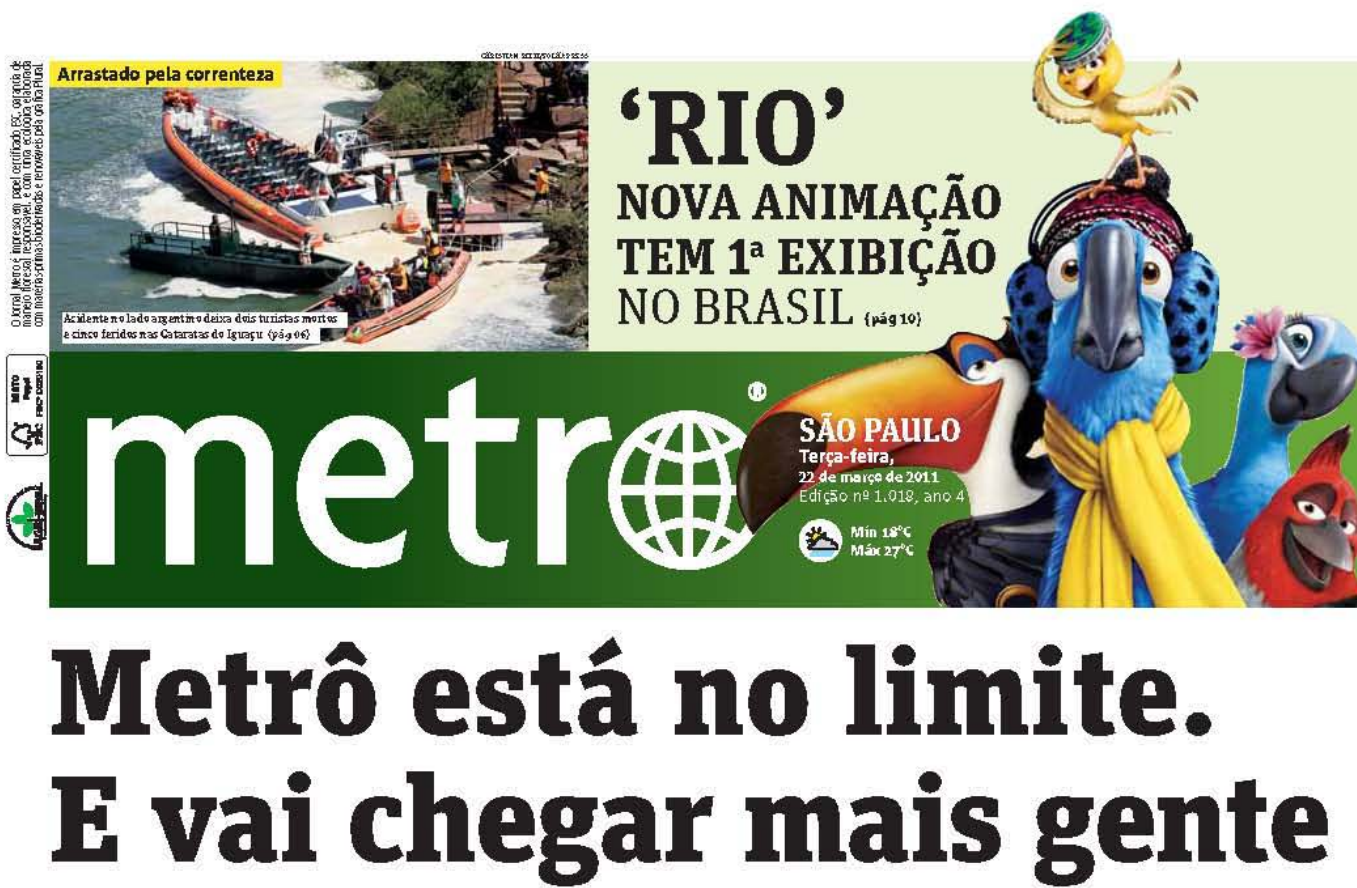

- Ampliação do horấrio de funcionamento das estações Tamanduateí e Vila Prudente vai levar mais 100 mil usuários ẩ Linha Verde $O$ No final de 2010, já eram 5,9 passageiros por $\mathrm{m}^{2}$ O Limite é de 6 por $\mathrm{m}^{2}$ \{pás ouł

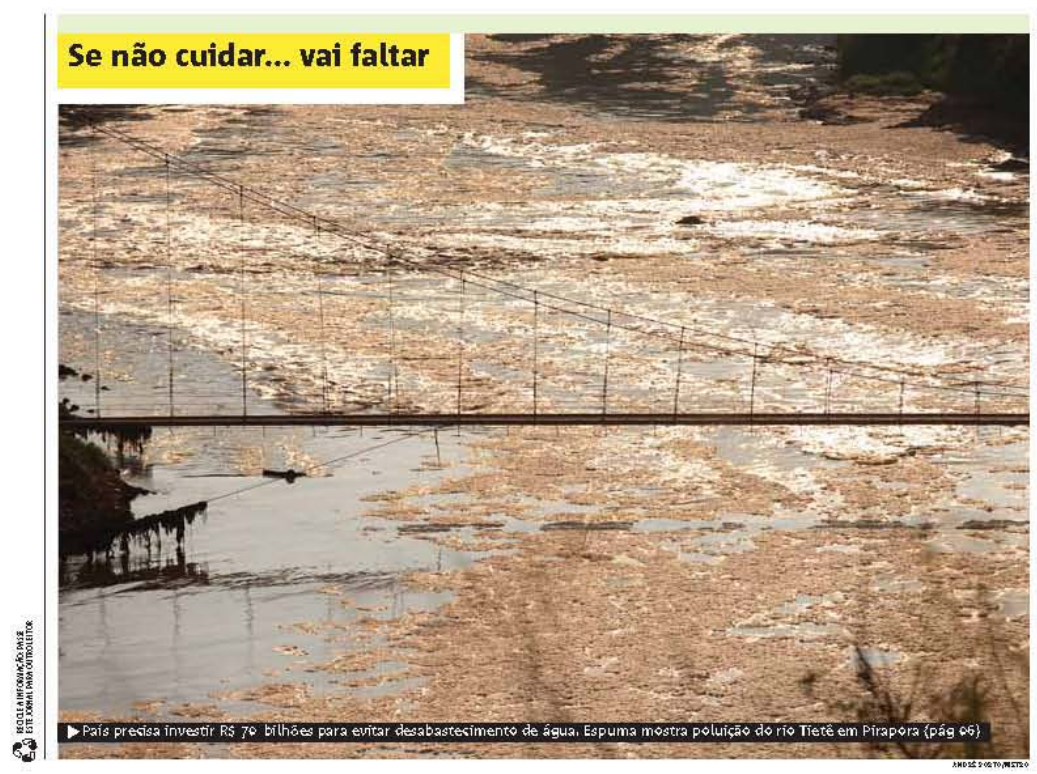

Intervençăo na Libia

Região onde Kadafi mora é bombardeada por aliados

Dobama diz que objetivo ê proteger civis, rata tirar ditador liderança a aliados \{pág og!

Gilberto Kassab cria novo partido, o PSD

Prefeito tem a maior índice de reprovaçẫo da sua gestäo \{rág o2 $\}$

Reduza a sua conta de água

Refonma simples, de $R \$ 150$, pode diminuir a consumo e gerar uma ecomomia de atế $50 \%$ \{pág or) 


\title{
5. CONSIDERAÇÕES FINAIS
}

\section{NO MEIO DO CAMINHO ENTRE JORNALISMO E PUBLICIDADE}

\author{
Em outubro de 2008, a Associação Espanhola de Empresas de Publicações Periódicas
} reuniu-se em Madri para discutir o mercado da imprensa gratuita na Espanha, um dos mais consolidados do mundo - há mais jornais de graça circulando no país do que periódicos pagos. Diretores de gratuitos de outras partes do mundo foram convidados, e o evento serviu para a fundação da Federação Internacional de Imprensa Gratuita. A recém-criada entidade elaborou, então, o Manifesto de Madri, um documento com dez princípios para esse segmento da mídia impressa. São estes os pontos:

1. La prensa y las publicaciones gratuitas constituyen uno de los fenómenos más relevantes ocurridos en el campo de la comunicación y el periodismo durante los últimos años

2. La prensa y las publicaciones gratuitas fomentan la lectura y permiten un mejor y mayor acceso de los ciudadanos a la información, a la cultura, a la participación social y a los hábitos democráticos

3. La prensa y las publicaciones gratuitas desempeñan un importante papel social, crean tejido cívico y fomentan la cohesión en las comunidades de lectores a las que se dirigen

4. La prensa y las publicaciones gratuitas suponen un refuerzo del derecho a la libertad de expresión y del resto de libertades públicas en las sociedades democráticas

5. La prensa y las publicaciones gratuitas, que se elaboran con criterios de calidad máximos, han supuesto una innovación en el ejercicio del periodismo, y los profesionales que las elaboran lo hacen con criterios de máxima calidad, ética, rigor e independencia

6. La prensa y las publicaciones gratuitas son agentes beneficiosos para la economía en su conjunto, ya que crean empleo y riqueza, fomentan la competencia y suponen un freno a los precios

7. La prensa y las publicaciones gratuitas facilitan a los anunciantes unas vías innovadoras y más eficaces para dar a conocer sus productos y servicios a los ciudadanos

8. La prensa y las publicaciones gratuitas instan a las instituciones públicas a ser tratadas con equidad tanto en el suministro de la información como en el reparto de la publicidad institucional

9. La prensa y las publicaciones gratuitas crean nuevos lectores, por lo que contribuyen al desarrollo y al futuro del conjunto de medios de comunicación 10. La prensa y las publicaciones gratuitas son, en definitiva, un bien público $^{19}$

\footnotetext{
${ }^{19}$ Manifiesto de Madrid, 02/10/2008. Tradução do autor: 1. A imprensa e as publicações gratuitas constituem um dos fenômenos mais relevantes ocorridos no campo da comunicação e do jornalismo durante os últimos anos; 2 . A imprensa e as publicações gratuitas fomentam a leitura e permitem um melhor e maior acesso dos cidadãos à informação, à cultura, à participação social e aos hábitos democráticos; 3. A imprensa e as publicações gratuitas desempenham um importante papel social, criam tecido cívico e fomentam a coesão nas comunidades de leitores às quais se dirigem; 4 . A imprensa e as publicações gratuitas supõem um reforço do direito à liberdade de expressão e do resto das liberdades públicas nas sociedades democráticas; 5. A imprensa e as publicações gratuitas, que se elaboram com máximos critérios de qualidade, supõem uma inovação no exrercício do jornalismo, e os profissionais que os elaboram o fazem com critérios de máxima qualidade, ética, rigor e independência; 6. A imprensa e as publicações gratuitas são agentes benéficos para a economia em seu conjunto, já que criam emprego e riqueza, fomentam a competição e supõem um freio sobre os preços; 7. A imprensa e as publicações gratuitas facilitam, aos anunciantes, vias inovadoras e mais eficazes para fazer com que os cidadãos
} 
Como quase todo manifesto, este não foge de posições genéricas sobre valores universais do jornalismo. Mas decidimos reproduzi-lo na íntegra para abrir as considerações finais por causa de um dos pontos do documento, mais especificamente o de número 7. Esta pesquisa buscou demonstrar por que Metro e Destak podem ser chamados de diários gratuitos modernos, em contraste com os modelos anteriores de periódicos sem custo ao leitor. A diferença primordial reside no fato de como esses veículos estabeleceram uma nova relação com a linguagem publicitária.

O Manifesto de Madri tem razão ao dizer que a imprensa gratuita pós-Metro permitiu aos anunciantes "vias inovadoras e eficazes” para divulgar seus produtos. Essas vias, aliás, tendem a precipitar uma redefinição de parâmetros entre jornalismo e publicidade. A convivência entre essas duas áreas, como vimos, vem de séculos e se intensificou ao longo do tempo. As razões para essa aproximação são várias: lucro como objetivo último comum, público-alvo semelhante, estratégias de atração convergentes. Era natural que a linguagem usada nesses dois discursos caminhasse para entrecruzamentos e hibridismos. Formatos diferentes de anúncios são uma realidade já bem conhecida no mercado jornalístico. O que se propôs avaliar aqui foi a evolução desse imbricamento a um patamar do qual não se tinha conhecimento anterior - eis o “inovadoras” das vias descritas pelo manifesto. É exatamente por essa relação íntima com a publicidade que os gratuitos surgiram, se desenvolveram e hoje fazem parte de um cenário consolidado na mídia mundial - e em clara consolidação no mercado brasileiro, mesmo com apenas cinco anos de vida. Destak e Metro não teriam sobrevivido se não tivessem conseguido chamar a atenção de seus anunciantes, simplesmente a fonte única de sustentação desses veículos - daí o termo “eficazes” apresentado no documento. O emprego da Análise de Discurso e da dialogia bakthiniana nos foi deveras útil para entender como funciona a lógica dessa relação e como ela é fundamental para que os gratuitos alcancem o seu público visado: os jovens urbanos de classe média-alta, ou os urbanites, como gosta de dizer o Metro. Observamos que o imbricamento não se faz presente apenas nos anúncios, mas também em chamadas de capa que, mesmo fazendo parte de um gênero discursivo marcadamente jornalístico, operam com vários elementos do discurso publicitáriopara ser mais eficientes.

conheçam seus produtos e serviços; 8. A imprensa e as publicações gratuitas instam às instituições públicas ser tratadas com equidade, tanto no fornecimento de informação como no reparte da publicidade institucional; 9. A imprensa e as publicações gratuitas criam novos leitores, contribuindopara o desenvolvimento e para o futuro do conjunto dos meios de comunicação; 10. A imprensa e as publicações gratuitas são, definitivamente, um bem público. 
É evidente que a abertura de novos campos de contato com a publicidade que esses diários gratuitos proporcionam é compreendida de diferentes maneiras, de acordo com o observador. Do ponto de vista de quem anuncia, a chegada desses periódicos ao Brasil foi obviamente vista como algo positivo. Afinal, a existência deles acirra a competição com outros jornais por anúncios e tende a baixar os preços cobrados pelo espaço publicitário no papel. Já sob a ótica dos jornalistas, as opiniões variam conforme a posição dentro do mercado. Os profissionais, em geral, comemoram sempre que um novo veículo é lançado, pois a oferta de emprego geralmente aumenta. Não lhes importa se um diário gratuito está comprometido com um jornalismo “de qualidade” ou não. Aos que estudam o discurso jornalístico e defendem uma versão purista desse campo do conhecimento, não lhes agrada a ideia de um veículo que segue os padrões básicos do jornalismo, mas não se furta a ceder ao discurso publicitário espaços considerados “inegociáveis” - basta retomar o raivoso artigo de Alberto Dines a respeito do anúncio curso de inglês Red Balloon na capa da Folha de S. Paulo, como descrevemos no capítulo anterior. Ou, numa escala de maior gravidade, relembrar os violentos protestos de sindicatos ligados aos jornais tradicionais franceses contra a chegada do Metro, em 2001, quando os gratuitos eram temidos por sua "iniciativa puramente publicitária” (EDO, 2004).

Essa polarização, porém, não encontra fundamentação na realidade, pois trata tanto jornalismo quanto publicidade como discursos estanques, imiscíveis, como se o único contato entre eles fosse “forçado" pela proximidade entre anúncio e notícia na página de um periódico. Enxergar o fenômeno dos gratuitos dessa forma é não levar em conta o benefício mútuo dessa relação. É válido discutir se há excessos em determinados momentos, mas negar a possibilidade da hibridização é ignorar a própria ideia bakhtiniana do enunciado como uma constante reapropriação de já-ditos. Por mais que funcione sob certas normas e expectativas tanto da parte do enunciador como do co-enunciador, nenhum gênero discursivo está imune à influência de um outro.

Como expusemos na introdução, esta pesquisa começou a ganhar forma depois da leitura de um artigo do jornalista Alcino Leite Neto na Folha de S. Paulo, em abril de 2002, sobre possíveis cenários para os jornais gratuitos quando estes chegassem ao Brasil, o que viria a ocorrer apenas quatro anos depois. Nesta parte final, julgamos ter mais elementos para “responder” aos prognósticos do articulista, dentro do que foi observado ao longo do trabalho. É o que será feito adiante: 


\section{1) Os gratuitos poderão ser dominantes no Brasil}

É inegável que os gratuitos se fixaram no Brasil e estão em expansão. Metro e Destak iniciaram suas operações apenas em São Paulo. Hoje, atuam em Campinas, Santos, ABC, Brasília, Curitiba e Rio de Janeiro, com uma tiragem diária total que se aproxima de 600 mil exemplares. Trata-se de um número significativo para tão pouco tempo de mercado no Brasil, mas nada sugere, até agora, que os gratuitos suplantarão os jornais pagos, o que já ocorre em alguns países da Europa. O sucesso dos dois principais gratuitos não foi acompanhado por outros títulos lançados depois deles - o esportivo Jornal Placar deixou de circular periodicamente e o MTV na Rua, voltado ao público jovem, foi fechado com apenas quatro meses de vida.

2) Os gratuitos poderão ganhar espaço em razão do baixo nível de escolaridade e da baixa renda da população

Eis uma das concepções equivocadas a respeito da identidade dos jornais gratuitos, ao menos no Brasil. A gratuidade e o fato de ser distribuído nas ruas causaram no mercado a expectativa de que esses veículos teriam como público-alvo classes sociais mais baixas e funcionariam como um importante mecanismo para a chamada democratização da informação. As pesquisas encomendadas pelos gratuitos não apontam para tal cenário. Os leitores de Metro e Destak são jovens com bom poder aquisitivo. A linha editorial voltada para o entretenimento e para a diversão privilegia esse público, mas não abre o leque para opções mais populares - por exemplo, há bastante ênfase no lançamento de filmes de animação no cinema ou de games para consoles modernos, algo que tende a excluir jovens pobres pelo fato de estes não terem condições financeiras de manter tais hábitos culturais. $\mathrm{O}$ próprio modelo de distribuição prioriza motoristas - e não pedestres, que provavelmente não têm como arcar com um carro. A expansão dos gratuitos trouxe, sim, mais leitores à mídia impressa, mas não de onde se podia esperar - de um público mais humilde e pouco afeito a jornais. Os outrora não-leitores foram captados de uma parcela da população que se acostumara a obter informação apenas pela internet ou por outros meios que não o impresso. Sob esse aspecto, não se pode falar propriamente em democratização.

\section{3) Os gratuitos não vão competir com os quality papers}

De fato, Metro e Destak não ocupam a mesma fatia do mercado onde estão O Estado de S. Paulo e a Folha de S. Paulo, para citar dois conhecidos quality papers. Isso não ocorre porque as propostas de público-alvo são bastante diferentes. Embora tragam informações 
sobre todos os assuntos, como um diário convencional, os gratuitos buscam sempre atrair um público mais jovem, que tende a ter certa resistência à mídia impressa tradicional. Por isso, os textos são muito curtos e não há nenhum espaço para análise ou opinião. Além disso, o noticiário político e econômico traz apenas o essencial; a ênfase está mesmo em pautas vinculadas à diversão e ao show business. Um quality paper tem como objetivo ser plural o suficiente para abarcar todas as faixas de leitores e cada vez mais se associa a um tipo de publicação mais analítica, opinativa, como forma de se diferenciar do conteúdo factual já oferecido à exaustão pela internet.

4) Os gratuitos vão ocupar o espaço de títulos populares das empresas jornalísticas

Esta é uma outra dedução errônea em relação aos gratuitos. Não é pelo fato de não competir com os jornais "nobres” que esses veículos necessariamente serão concorrentes dos títulos mais populares da mídia tradicional. Embora os leitores de gratuitos e populares possam ser os mesmos sob determinadas situações, o objetivo de Metro e Destak não é este. O fazer jornalístico desses veículos e os próprios depoimentos de seus editores, presentes nesta pesquisa, reforçam a busca de um leitor de classe A e B, essencialmente jovem, ao passo que periódicos populares, como o Agora, do Grupo Folha, apresentam grande rejeição entre leitores com melhor poder aquisitivo e adaptados a novas tecnologias. Os gratuitos indicam uma nova tendência jornalística; os populares estão ancorados em uma concepção de jornalismo que tem pouco apelo para os chamados urbanites.

5) As empresas jornalísticas tradicionais do Brasil vão se antecipar ao fenômeno e lançar seus próprios títulos gratuitos

A mídia impressa convencional não teve uma visão moderna de negócios que lhe permitisse vislumbrar vantagens com o lançamento de títulos gratuitos. Quando percebeu o ingresso dos jornais vindos de fora do Brasil, tentou obstruir sua existência de variadas maneiras. Agora, ao que parece, o mercado está adaptado à presença dos gratuitos modernos, mas não há evidências de que os grupos tradicionais tenham planos de criar os seus gratuitos. Até hoje, a única empresa jornalística brasileira que se associou à imprensa gratuita foi o Grupo Bandeirantes, que detém 70\% das ações do Metro no Brasil. 
Ao fim desta pesquisa, consideramos ter elucidado as estruturas atinentes ao discurso "publijornalístico” intrínseco ao ethos dos gratuitos modernos. A natureza desses veículos, embora se origine de uma matriz jornalística, guarda uma relação simbiótica com a linguagem publicitária. Para os mais radicais, nem podem ser chamados de jornal. Sim, eles o são, mas não mais sob o clássico formato ao qual nos acostumamos por séculos. Trata-se de um ser híbrido, verdadeiramente "um diferente tipo de animal”, como tão bem descreveu Bakker (2002). Um ente totalmente adaptado às condições do mercado, como afirmam Nizen \& Weintraub.

Free dailies make sense to readers, advertisers, and publishers. They can be read in 20 minutes at a convenient time on a subway, train, or bus during the morning commute. Free dailies are economical to develop, usually 40 to 45 employees providing entry-level positions to journalists and commissioned sales representatives. With the outsourcing of printing and circulation there is relatively little capital expense and overhead is low. With low investment and costs the advertising rates are significantly cheaper than the paid dailies and by limiting page counts advertisements have greater impact than in 100-page daily newspapers (NIZEN; WEINTRAUB, 2005) ${ }^{20}$

Levando em consideração esses aspectos econômicos, Bakker demonstra otimismo em relação ao futuro dos gratuitos. Diz que eles “estão aqui para ficar” (2002, p. 186) e, pelo fato de terem se provado atraentes a um público jovem, “o futuro se mostra relativamente límpido” (id., p. 12). Quase dez anos se passaram desde suas reflexões e não se pode dizer que Bakker não tenha acertado. No Brasil, os gratuitos modernos não demonstraram “o potencial transformador das publicações que a gente apanha de graça na padaria”, pelo menos não da maneira como supunha Alcino Leite Neto naquele mesmo ano de 2002, mas certamente transformaram o modo de se analisar as relações entre o discurso jornalístico e o publicitário. Eles estão bem no meio do caminho.

\footnotetext{
${ }^{20}$ Tradução do autor: “Jornais gratuitos fazem sentido para leitores, anunciantes e diretores de jornais. Podem ser lidos em 20 minutos, de um modo conveniente, no metrô, trem, ônibus ou durante o trajeto matutino para o trabalho. A abertura de diários gratuitos não é dispendiosa; usualmente são necessários de 40 a 45 empregados, dispondo de cargos de iniciante para jornalistas e de representantes de vendas comissionados.Com a terceirização da impressão e da distribuição há uma despesa relativamente pequena, e os custos fixos são baixos. Com um pequeno investimento e baixo custo, os preços para os anunciantes são significativamente mais baixos que os dos diários pagos e, pelo número limitado de páginas, os anúncios têm um impacto muito maior que em um jornal diário de 100 páginas.
} 


\section{REFERÊNCIAS BIBLIOGRÁFICAS}

AMOSSY, Ruth. "O ethos na intersecção das disciplinas: retórica, pragmática, sociologia dos campos”. In: (org.). Imagens de si no discurso - a construção do ethos. São Paulo:

Ed. Contexto, 2011.

ARROYO, María Cabello. "Impacto de la prensa gratuita em los jóvenes: algunas claves Del fenômeno mediático”. In: XXI Congreso Internacional de la Comunicación “Los Jóvenes y el Nuevo Escenario de la Comunicación”. Pamplona, 2008.

AUTHIER-REVUZ, Jacqueline. "Heterogeneidade (s) Enunciativa (s)”. In: Caderno de Estudos Linguísticos, n 19, Campinas: jul./dez, 1990, pp. 25-42.

BAKHTIN, Mikhail. “Os gêneros do discurso”. In: BAKHTIN, M. Estética da criação verbal. São Paulo: Martins Fontes, 2003. pp. 261-306.

Marxismo e Filosofia da Linguagem: problemas fundamentais do método sociológico na ciência da linguagem. São Paulo: HUCITEC, 1997.

BAKKER, Piet. "Free Daily Newspapers - Business Models and Strategies”. In: The International Journal on Media Management, Vol. 4., nº 3, 2002, pp. 180-187.

“Reinventing newspapers; Free dailies - readers and markets”. Maio/2002.

Disponível em: http://www.newspaperinnovation.com/wp-content/uploads/bakker2002.pdf [acessado em 02/08/2011]

BARBOSA, Ivan Santo; CASAQUI, Vander. “Linguagem publicitária e jornalística: uma aproximação dialógica”. In: Líbero, Vol. 3, nº 6, São Paulo: 2000, pp. 70-79.

; TRINDADE, Eneus. “O NIELP: paradigmas para a análise da linguagem publicitária”. In: Líbero, ano IV, v. 4, ns. 7-8, São Paulo: Faculdade Cásper Líbero, p. 112-121.

BARROS, Diana Luz Pessoa de; FIORIN, José Luiz. (orgs.). Dialogismo, Polifonia, Intertextualidade: em torno de Bakhtin. São Paulo: Edusp, 1999.

BENETTI, Marcia. “Análise do Discurso em jornalismo: estudo de vozes e sentidos”. In: LAGO, Cláudia; (orgs.). Metodologia de Pesquisa em Jornalismo.

Petrópolis: Vozes, 2010.

BIZZOCCHI, Aldo Luiz. Anatomia da cultura: uma nova visão sobre ciência, arte, religião, esporte e técnica. São Paulo: Palas Athena, 2003.

BOURDIEU, Pierre. Sobre a Televisão. Rio de Janeiro: Jorge Zahar Editor, 1997.

BRAIT, Beth. "Bakhtin e a natureza constitutivamente dialógica da linguagem. In:

(org.). Bakhtin, dialogismo e construção de sentido. Campinas: UNICAMP, 1997. 
“Texto jornalístico: modos de leitura”. In: Estudos linguísticos XXXIX. Anais de Seminários do GEL, v. 39, n. 1, Franca: Unifran, 1991, pp. 85-92.

CANCLINI, Néstor García. Consumidores e cidadãos - conflitos multiculturais da globalização. Rio de Janeiro: Editora UFRJ, 1999.

CARRERA, Fernanda Ariane Silva. "Gêneros jornalístico e publicitário: uma análise das possíveis semelhanças a partir de suas estratégias discursivas.” In: $5^{\circ}$ Encontro Nacional de Pesquisadores em Jornalismo, Universidade Federal de Sergipe, 15 a 17/11/2007.

CASAQUI, Vander. Polifonia publicitária: das construções da "realidade” jornalística à da retórica em publicidade - uma análise dialógica. [Dissertação de Mestrado]. São Paulo: Escola de Comunicações e Artes da Universidade de São Paulo: 2000.

Polifonia publicitária: das construções da “realidade” jornalística à da retórica em publicidade - uma análise dialógica. In BARBOSA, Ivan Santo (org.). Os sentidos da publicidade - Estudos interdisciplinares. São Paulo: Thomson Learning, 2005. pp. 29-50.

CASTAÑO, Yolanda Arrebola. La prensa local gratuita en Málaga. In: LITA, Rafael López; BELTRÁN, Francisco Fernández; MAÑÉS, Ángles Durán (orgs). La prensa local y la prensa gratuita. Castelló de la Plana: Publicacions de la Universitat Jaume I, 2002.

CHARAUDEAU, Patrick; MAINGUENEAU, Dominique. Dicionário de Análise de Discurso. São Paulo: Ed. Contexto, 2004.

. Discurso das mídias. São Paulo: Ed. Contexto, 2010.

CHIMINAZZO, Ricardo. “Tendências e novos formatos das peças publicitárias”. In: PEREZ, Clotilde; BARBOSA, Ivan S. (orgs.). Hiperpublicidade, v. 2 - atividades e tendências. São Paulo: Thomson Learning, 2008, pp. 448-479.

COAN, Emerson Ike. A relação entre os discursos publicitário e jornalístico no

domínio do entretenimento. [Dissertação de Mestrado]. São Paulo: Faculdade Cásper Líbero, 2010.

DASCAL, Marcelo. “O ethos na argumentação: uma abordagem pragma-retórica”. In: AMOSSY, Ruth. Imagens de si no discurso - a construção do ethos. São Paulo: Ed. Contexto, 2011.

DINES, Alberto. “'Folha-shit’, a invenção genial”. In: Observatório da Imprensa, ed. 647, 21/06/2011.

EDO, Concha. "El éxito de los gratuitos hace más visible la crisis de la prensa diaria de pago" In: Estudios sobre el mensaje periodístico, Vol. 11. Madrid: 2005, pp. 23-44. 
“La prensa gratuita se abre paso entre los medios de información general.’In:

Sala de Prensa, año VI, Vol. 3, 2004. Disponível em http://www.saladeprensa.org/art539.htm. [acessado em 02/08/2011]

EGGS, Ekkehard. "Ethos aristotélico, convicção e pragmática moderna”. In: AMOSSY, Ruth. Imagens de si no discurso - a construção do ethos. São Paulo: Ed. Contexto, 2011. FERRARA, Lucrécia. A estratégia dos signos. São Paulo: Perspectiva, 1986.

GRILLO, Sheila Vieira de Camargo. “A estreita convivência entre notícia e anúncios na página dos jornais”. In: INTERCOM - Revista Brasileira de Comunicação. Vol. XXVI, $\mathrm{n}^{0} 1$, São Paulo: 2003, pp. 47-64.

VELOSO, Simone Ribeiro de Ávila. “Diálogos entre Maingueneau e o Círculo de Bakhtin”. In: Filologia e Linguística Portuguesa, nº 9, São Paulo: 2008, pp. 229-251.

- "Gêneros Primários e Gêneros Secundários no Círculo de Bakhtin: Implicações para a Divulgação Científica”. In: Alfa, Vol. 52. São Paulo: 2008, pp. 57-79.

HADDAD, Galit. "Ethos prévio e ethos discursivo: o exemplo de Romain Rolland". In: AMOSSY, Ruth. Imagens de si no discurso - a construção do ethos. São Paulo: Ed. Contexto, 2011.

HAUG, Wolfgang Fritz. A crítica da estética da mercadoria. São Paulo: Ed.UNESP, 1997. IANNI, Octávio. Teorias da Globalização. Rio de Janeiro: Civilização Brasileira, 2000. LAMPREIA, Joaquim Martins. A Publicidade Moderna. Lisboa: Editorial Presença, 1983. LIPOVETSKY, Guilles. O Imperio do Efêmero. São Paulo: Companhia das Letras, 1989. LOPES, Maria Immacolata Vassalo de. Pesquisa em comunicação. São Paulo: Edições Loyola, 2003.

MAINGUENAU, Dominique. Novas tendências em análise de discurso. Campinas: Pontes, 1989.

Análise de textos de comunicação. São Paulo: Cortez, 2008. “Ethos, cenografia, incorporação”. In: AMOSSY, Ruth.

Imagens de si no discurso - a construção do ethos. São Paulo: Ed. Contexto, 2011.

MAZON, Letícia Nigro. O modelo econômico do jornal diário gratuito: Metro International e Publimetro, um estudo de caso. [Trabalho de Conclusão de Curso]. São Paulo: Escola de Comunicações e Artes da Universidade de São Paulo, 2008.

NETO, Alcino Leite. “Pão e jornais para todo mundo”. Folha Online, 05/04/2002. Disponível em http://www1.folha.uol.com.br/folha/pensata/ult682u30.shtml [acessado em 02/08/2011] 
NIZEN, Don; WEINTRAUB, Floyd. "Free dailies bring younger readers back to newspapers”. In: Ideas Magazine, 2005. Disponível em http://www.inma.org (para assinantes). [acessado em 02/08/2011].

PICARD, Robert. “Strategic Responses to Free Distribution Daily Newspapers”. In: The International Journal on Media Management. Vol. III, n 3, 2001, pp. 167-172.

POSSENTI, Sirio. “Observações sobre Interdiscurso”. In: Revista Letras, $\mathrm{n}^{0}$ 61, Curitiba: 2003, pp. 253-269.

ROBERTSON, Roland. Globalização - Teoria social e cultura global. Petrópolis: Editora Vozes, 2000.

SANTAELLA, Lucia. Semiótica aplicada. São Paulo: Pioneira Thomson Learning, 2002. Manifiesto de Madrid. In: I Congreso Mundial de Prensa y Publicaciones Gratuitas, Madrid, 02/10/2008.

SAUSSURE, Ferdinand de. Curso de linguística geral. São Paulo: Cultrix, 2006.

SOBRAL, Adail. "Estética da Criação Verbal”. In: BRAIT, Beth (org.). Bakthin Dialogismo e Polifonia. São Paulo: Ed. Contexto, 2009

SORJ, Bernardo. A nova sociedade brasileira. Rio de Janeiro: Jorge Zahar Editor, 2000.

TRAQUINA, Nelson. Teorias do Jornalismo. Florianópolis: Insular, 2005

TRINDADE, Eneus. “A publicidade e a modernidade-mundo: As representações de pessoa, espaço e tempo”. In: BARBOSA, Ivan Santo (org.). Os sentidos da publicidade: estudos interdisciplinares. São Paulo: Pioneira Thomson Learning, 2005, pp. 81-95. 